\title{
National Ignition Facility Project Execution Plan
}

\author{
E. Moses
}

August 1, 2000

U.S. Department of Energy

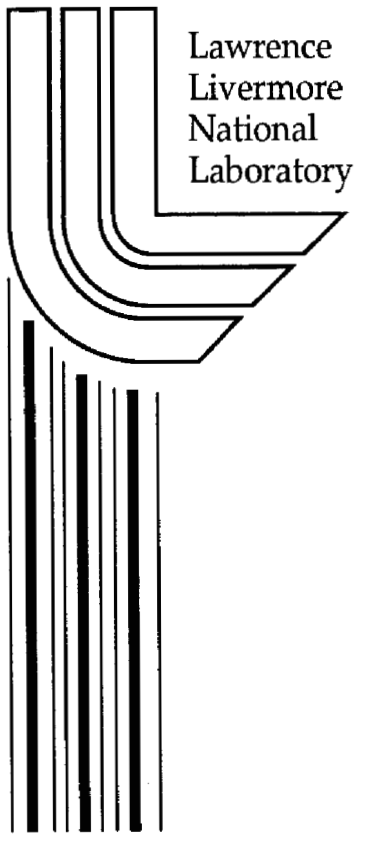




\section{DISCLAIMER}

This document was prepared as an account of work sponsored by an agency of the United States Government. Neither the United States Government nor the University of California nor any of their employees, makes any warranty, express or implied, or assumes any legal liability or responsibility for the accuracy, completeness, or usefulness of any information, apparatus, product, or process disclosed, or represents that its use would not infringe privately owned rights. Reference herein to any specific commercial product, process, or service by trade name, trademark, manufacturer, or otherwise, does not necessarily constitute or imply its endorsement, recommendation, or favoring by the United States Government or the University of California. The views and opinions of authors expressed herein do not necessarily state or reflect those of the United States Government or the University of California, and shall not be used for advertising or product endorsement purposes.

This work was performed under the auspices of the U. S. Department of Energy by the University of California, Lawrence Livermore National Laboratory under Contract No. W-7405-Eng-48.

This report has been reproduced directly from the best available copy.

Available electronically at http://www.doc.gov/bridge

Available for a processing fee to U.S. Department of Energy

And its contractors in paper from

U.S. Department of Energy

Office of Scientific and Technical Information

P.O. Box 62

Oak Ridge, TN 37831-0062

Telephone: (865) 576-8401

Facsimile: (865) 576-5728

E-mail: reports@adonis.osti.gov

Available for the sale to the public from

U.S. Department of Commerce

National Technical Information Service

5285 Port Royal Road

Springfield, VA 22161

Telephone: (800) 553-6847

Facsimile: (703) 605-6900

E-mail: orders@ntis.fedworld.gov

Online ordering: http://www.ntis.gov/ordering.htm

OR

Lawrence Livermore National Laboratory

Technical Information Department's Digital Library

http:/ / www.llnl.gov/tid/Library.html 


\section{National Ignition Facility Project Execution Plan}

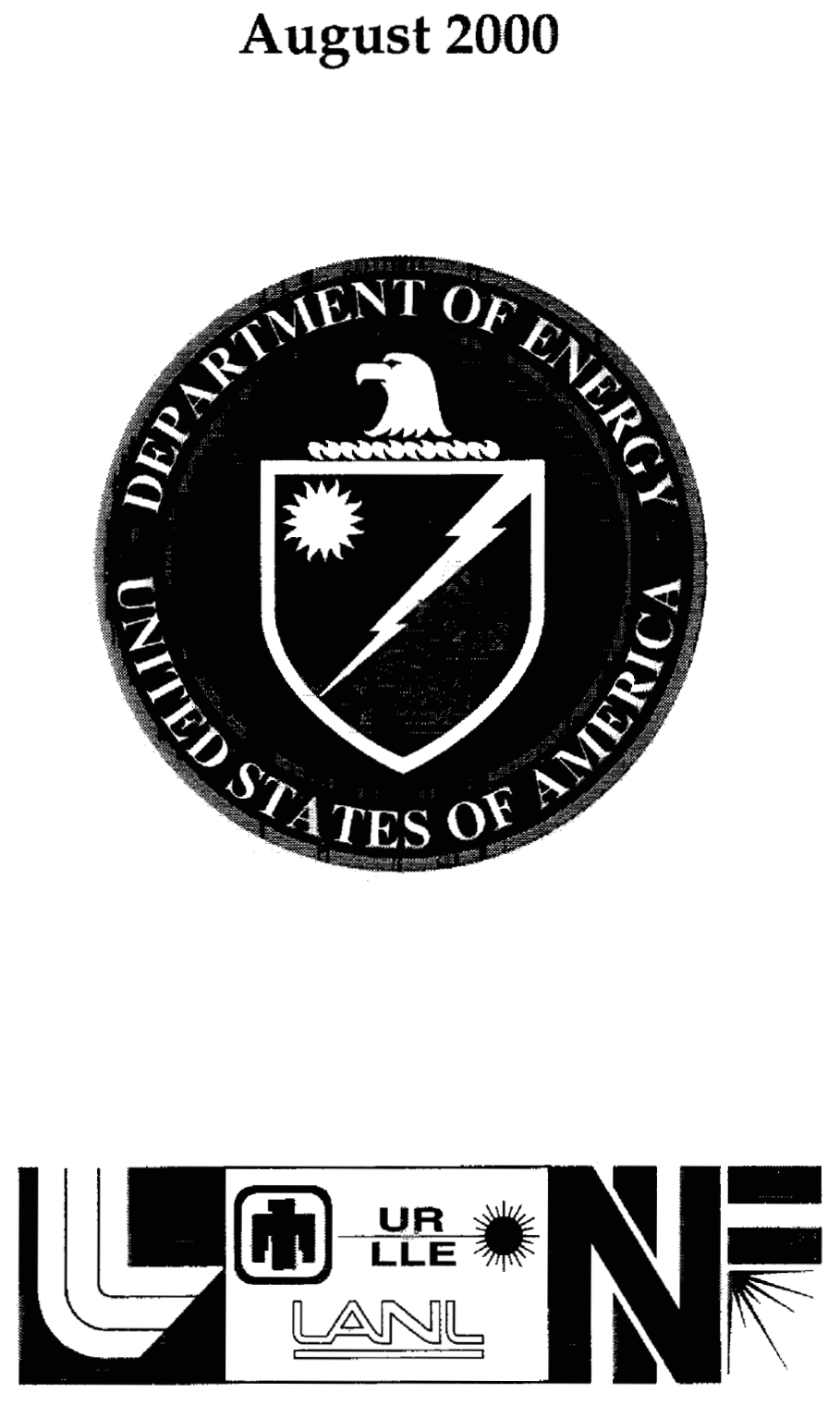





\section{National Ignition Facility}

\section{Project Execution Plan}

\section{Revision 2a}
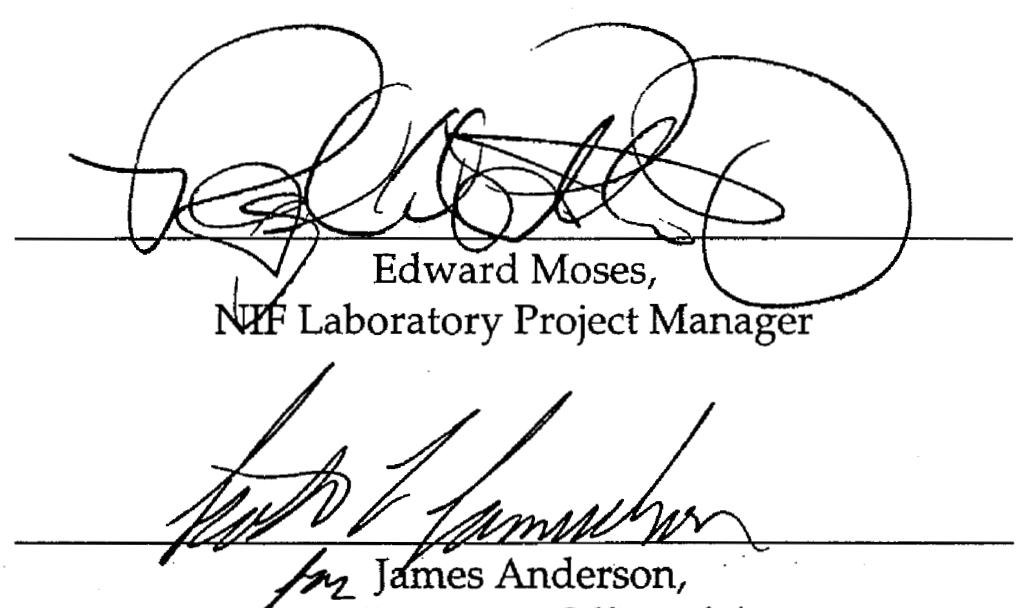

Director, Defense Programs Office of the NIF Project

Madelyn R. Creedon,

NNSA Deputy Administrator for Defense Programs 



\section{Table of Contents}

1. Justification of Mission Need ...................................................................... 1

2. Project Description ................................................................................................ 2

2.1 Primary Criteria .................................................................................... 2

2.1.1 Performance Requirements .............................................................. 2

2.1.2 Assurance Criteria............................................................................ 3

2.2 NIF Summary Design Description............................................................ 3

2.3 NIF Work Breakdown Structure ............................................................... 7

3. Management Roles and Responsibilities.................................................. 8

3.1 Deputy Administrator, NNSA Defense Programs..................................... 8

3.2 Director, NNSA Office of the NIF Project ................................................ 8

3.3 Deputy Director, NNSA Office of the NIF Project/Field Manager .......... 9

3.4 Associate Director for NIF Programs ………............................................... 9

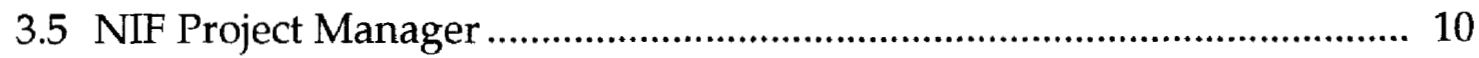

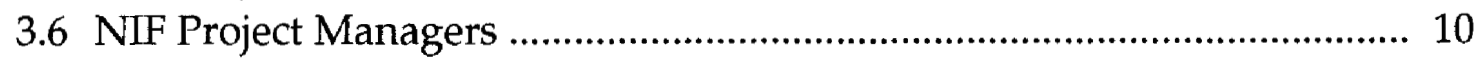

3.7 Institutional Deputy Project Managers ....................................................... 11

4. Project Execution ..................................................................................................... 13

4.1 Baseline Establishment ........................................................................... 13

4.1.1 Technical Baseline ..................................................................... 13

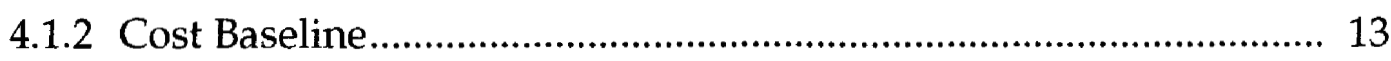

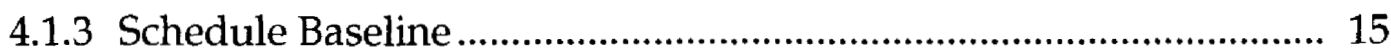

4.2 Baseline Change and Contingency Control ................................................ 15

4.2.1 Baseline Change Control and Configuration Control....................... 15

4.2.2 Contingency Control...................................................................... 18

4.3 NNSA Budget Authorization Process ………......................................... 18

4.4 Procurement and Contracting.................................................................. 19

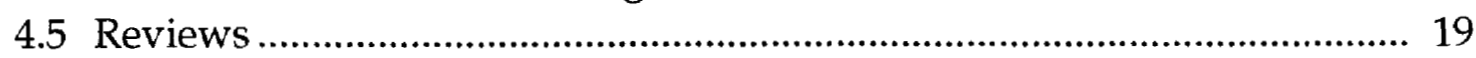

4.5.1 NNSA Status and Independent Reviews ........................................ 19

4.5.1.1 NIF Program Review Committee (PRC) ............................ 19

4.6 Performance Control and Reporting Systems .......................................... 19

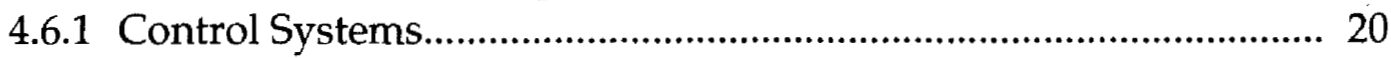

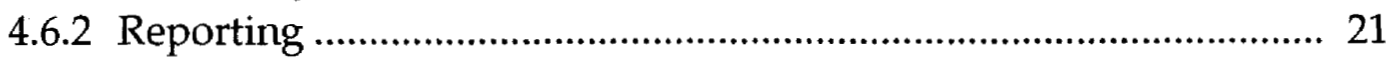

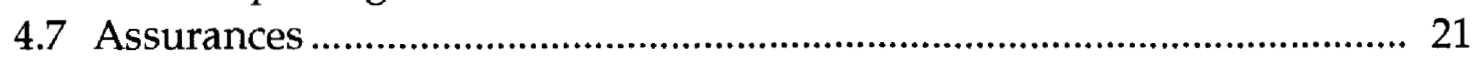

4.7.1 Quality Assurance............................................................................ 21

4.7.2 Environmental Safety and Health Planning ……............................ 22

4.7.2.1 NEPA Determination and Site Selection .............................. 22

4.7.2.2 Safety Documents............................................................ 23

4.7.2.3. Construction Safety Program .............................................. 24 
5. Method of Accomplishment 25

5.1 NIF Execution

5.1.1 Conceptual and advanced Conceptual Design. 25

5.1.2 Title I Design 25

5.1.3. Title II Design 25

5.1.4 Title III Engineering 26

5.1.5. Construction and Equipment Procurement, Installation, and Acceptance 26

5.1.6 Operational Testing and Commissioning . 27

5.1.7 Project Completion.

5.2 Security

6. Effective Date and Amendments. 28

7. References. 29 


\section{Appendices}

Appendix A. Acronyms and Abbreviations ……........................................................... 31

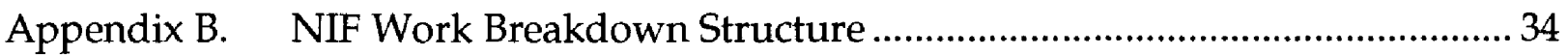

Appendix C. NIF Project Work Logic Diagram.......................................................... 36

Appendix D. NIF Project Data Sheet ............................................................................. 39

Appendix E. NIF Project Baseline Costs ....................................................................... 54

Appendix F. NIF Project Integrated Schedule, Major Milestones and

Critical Decisions, and NIF Project Documents....................................... 56

Appendix G. Key Decision 1 (Critical Decision 2) Approval Letter,

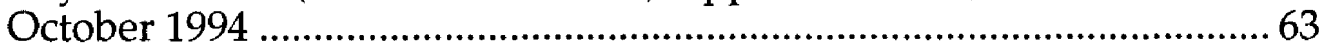

Appendix H. Approval of Baseline Change Action, March 1997 .................................69

Appendix I. C Critical Decision 3 Approval Memorandum, March 1997 ..................... 73

Appendix J. NIF Functional Requirements and Primary Criteria ...............................77

Appendix K. NIF Project Completion Criteria …........................................................ 108 



\section{Justification of Mission Need}

The National Ignition Facility (NIF) Justification of Mission Need, ${ }^{1}$ which was approved by the Secretary of Energy in January 1993, defines the mission of the National Inertial Confinement Fusion (ICF) Program and discusses the specific mission of the NIF Project. The NIF experimental capability will allow nuclear-weapons scientists to assess stockpile problems, verify computational tools, test for nuclear-weapons effects, and increase their understanding of weapons physics. The three weapons laboratory directors and the National Nuclear Security Administration (NNSA) Deputy Administrator for Defense Programs have reviewed the role of the NIF in Stockpile Stewardship in a joint letter. ${ }^{2}$ Along with the Accelerated Strategic Computing Initiative numerical simulations and other aboveground experimental facilities, the NIF will provide critical data that will allow the United States to maintain its technical capabilities in nuclear weapons in the absence of underground testing. As a secondary objective, the NIF will advance our understanding of ICF and help to assess its potential as an energy source. Achieving fusion ignition in the NIF will advance both defense and energy objectives. In affirming the Project's Critical Decision 2,* "Approval of New Start, ${ }^{\prime \prime}$ the Secretary of Energy verified the mission need and emphasized that the NIF has the potential to contribute significantly to the DOE missions.

\footnotetext{
*Although Key Decisions 0, 1', and 1 have already occurred, the Key Decision process is being phased out and a Critical Decision process is being implemented. The correlations between Key Decisions and Critical Decisions are: Key Decision $0=$ Critical Decision 1 (Approval of Mission Need); Key Decision 1 = Critical Decision 2 (Approval of New Start); Key Decision 2 (Start Final Design) is no longer used and has no Critical Decision equivalent; Key Decision 3 (Start Construction = Critical Design 3); and Key Decision $4=$ Critical Decision 4 (Project Completion).
} 


\section{Project Description}

Description and participants-The NIF Project is a NNSA Major System. The Project provides the design, facility construction, equipment procurement, and acceptance testing of the NIF. The Project, located at Lawrence Livermore National Laboratory (LLNL), involves LLNL, Los Alamos National Laboratory (LANL), Sandia National Laboratories (SNL), and the University of Rochester Laboratory for Laser Energetics (UR/LLE).

Cost and timeline-The current cost and schedule basis is described in the NIF Project Data Sheet in Appendix D, which shows a Total Estimated Cost of \$2,095.8 million and a Total Project Cost of \$2,249.0 million, with completion in fiscal year 2008.

Selected site-The Record of Decision ${ }^{4}(R O D)$ for the Stockpile Stewardship and Management Programmatic Environmental Impact Statement ${ }^{5}$ (SSMPEIS), issued in December 1996 by the Secretary of Energy, specified LLNL as the selected site.

\subsection{Primary Criteria}

The National Ignition Facility Functional Requirements and Primary Criteria ${ }^{6}$ represents the top-level system requirements that must be achieved to support the National Ignition Facility Justification of Mission Need, ${ }^{1}$ and to ensure that the construction and operation meet applicable federal, state, and local requirements to ensure protection of workers, the public, and the environment. These criteria also address the Project assurance requirements (e.g., Security, quality assurance) last updated in 1997. The primary criteria, approved by the NIF Project and the NNSA Office of the NIF Project, are the basis for the NIF Technical Baseline. All proposed changes to the approved primary criteria are subject to review and approval by the Level 1 Baseline Change Control Board (BCCB), chaired by the NNSA Deputy Administrator for Defense Programs. The performance requirements and the principal primary criteria for NIF systems are listed in the following sections.

\subsubsection{Performance Requirements}

The primary NIF performance requirements, defined in the National Ignition Facility Functional Requirements and Primary Criteria, ${ }^{6}$ can be summarized as follows:

- Each beam will have the specified energy and power encircled in a 600- $\mu \mathrm{m}$ laser spot size at the target plane with spatial and temporal beam conditioning to control intensity fluctuations.

- The facility will be designed to use two-sided target irradiation geometry, with two cones of beams per side, and eightfold rotation symmetry. The beams will be pointed on target to within $50 \mu \mathrm{m}$ rms.

- The laser temporal pulse may have a maximum peak-to-foot contrast ratio of 50:1.

- The laser will deliver $500 \mathrm{TW} / 1.8 \mathrm{MJ}$ at $3 \omega$ to the laser entrance holes of the target hohlraum.

- The facility will support classified and unclassified experiments. 
- The maximum annual fusion yield will be $1200 \mathrm{MJ} / \mathrm{y}$ with a maximum credible DT fusion yield limit of $45 \mathrm{MJ}\left(1.6 \times 10^{19}\right.$ neutrons).

- The design life for permanent structures is at least 30 years with regular maintenance.

\subsubsection{Assurance Criteria}

The assurance criteria, contained in the NIF Functional Requirements and Primary Criteria, ${ }^{6}$ were developed by a joint LLNL/Department of Energy (DOE) team using a Work Smart Standards (WSS)-like process. ${ }^{7}$ Through a directive signed by the Manager of the Oakland Operations Office these criteria were placed in Appendix $G$ of the Contract 48 between the DOE and the University of California. ${ }^{8}$ These criteria (established for the duration of the Project) would be replaced after Critical Decision 4, Project Closeout, by the LLNL-approved institutional set of WSS to govern NIF operation. Since there is a period of a decade between the development of the original NIF WSS and the beginning of operations, a joint NNSA/LLNL team is reviewing potential gaps between the original WSS and the LLNL institutional WSS to determine if any Environmental Safety and Health $(E S \& H)$ criteria require an earlier transition. Any changes require the appropriate BCCB approval.

NIF must meet the following summarized assurance criteria:

- Hazards category: low hazard, radiological.

- Public dose will remain below $100 \mathrm{mrem} / \mathrm{y}$ from all exposure modes and $10 \mathrm{mrem} / \mathrm{y}$ from emissions of radionuclides in ambient air.

- The NIF will meet the requirements for an improved risk level of fire protection sufficient to meet DOE objectives.

- Waste management shall minimize the generation of waste at the source per applicable DOE orders.

- NIF safeguards and security will physically protect and control classified data and equipment.

\subsection{NIF Summary Design Description}

The laser will be capable of providing an output pulse with the required energy of $1.8 \mathrm{MJ}$ and an output pulse power of $500 \mathrm{TW}$ at a wavelength of $0.35 \mu \mathrm{m}$ with specified symmetry, beam balance, and pulse shape. Figure 2-1 shows the NIF experimental facility, which will house a multibeam, neodymium-doped glass laser capable of generating and delivering the pulses to a target chamber. In the 10-m-diameter shielded target chamber, the light from the NIF beams will be tightly focused to enable weapons physics and effects and ICF and physics experiments. 


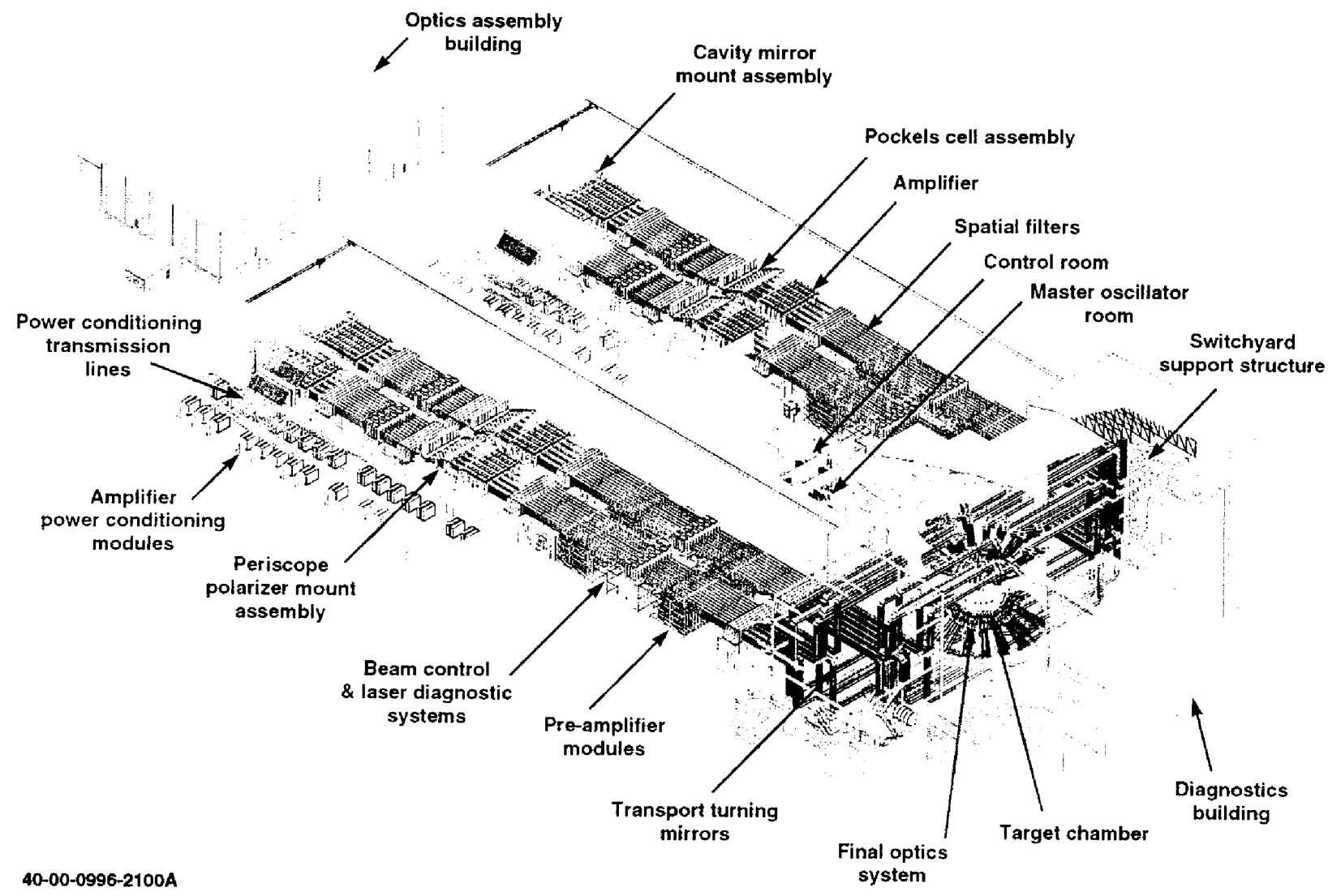

Figure 2-1. NIF Laser and Target Area Building.

User supplied diagnostics will be used to make the accurate measurements of the high temperature and pressure states of matter. The recorded data will be used by researchers involved in national security, energy, and basic science research.

The NIF consists of six primary systems described in the following paragraphs:

1. Conventional Facility.

2. Laser System.

3. Target Experimental Systems.

4. Integrated Computer Control Systems.

5. Assembly, Installation, and Refurbishment Equipment.

6. Utility Systems. 


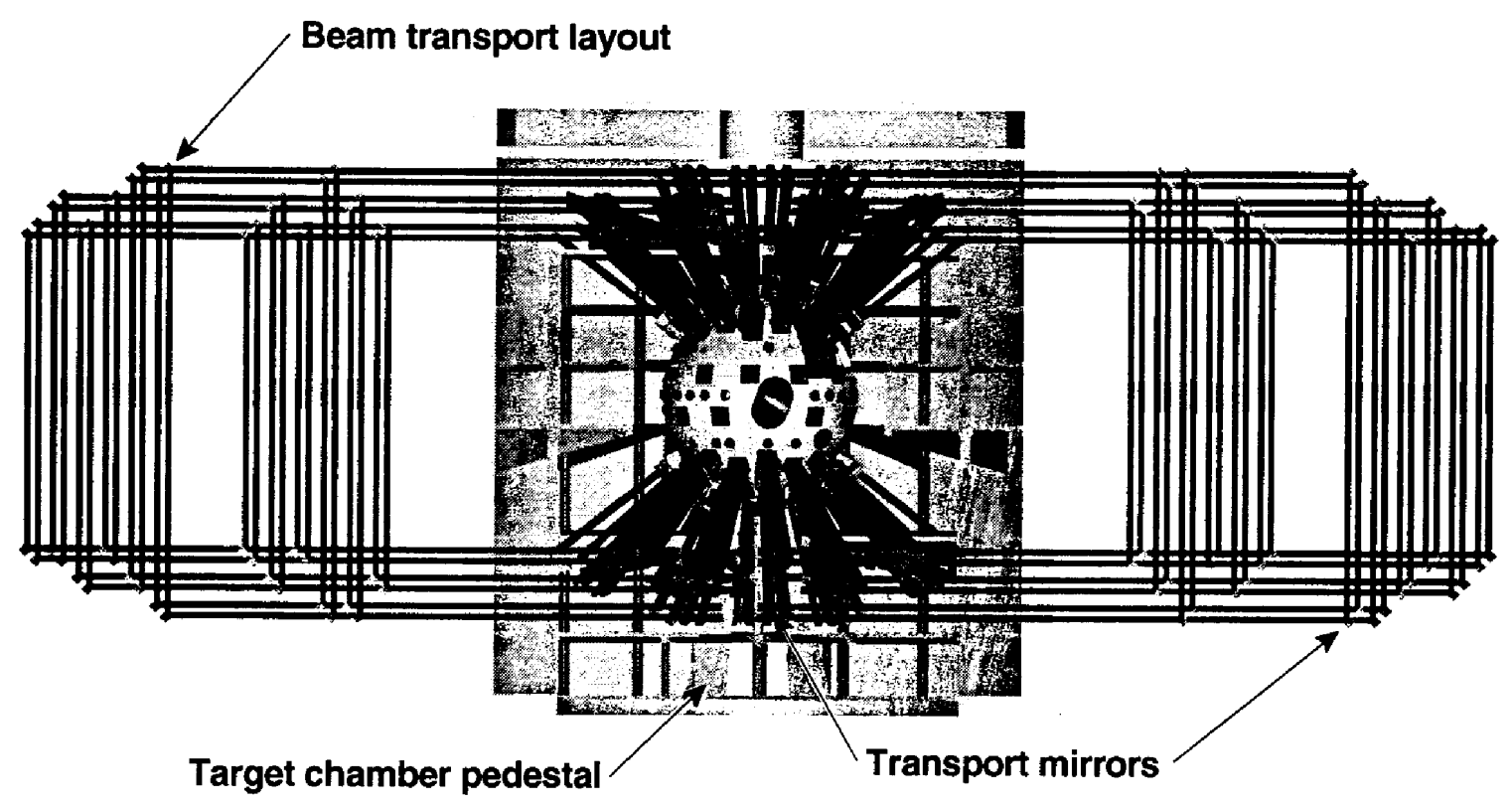

40-00-0796-1623Bpb01

10/7/96SAK

Figure 2-2. NIF Target Chamber.

Conventional Facilities-Facilities consist of the site, Laser and Target Area Building, Optics Assembly Building, and Support Facilities.

Laser and Target Area Building-The Laser and Target Area Building (shown in Figure 2-1) provides the environmentally controlled facility to house the NIF experimental systems. It is a reinforced-concrete and structural steel building with a footprint of approximately $20,300 \mathrm{~m} 2$. The building includes two laser bays, each approximately $31 \mathrm{~m}$ wide by $135 \mathrm{~m}$ long joined at a central target area, which is a shielded (1.8-m-thick concrete) cylinder approximately $32 \mathrm{~m}$ in diameter and about 32 $\mathrm{m}$ high. The target chamber (shown in Figure 2-2) is structurally supported in this cylinder. The Laser and Target Area Building, a heavily shielded structure, includes security systems, radioactive confinement and shielding, control rooms, supporting utilities, fire protection, monitoring, and decontamination and waste handling. Site improvements include grading, utilities, and landscaping.

Optics Assembly Building-This building has a footprint of $2600 \mathrm{~m} 2$ and provides about $1400 \mathrm{~m} 2$ of clean room area for optics assembly, mechanical cleaning, and optics and mechanical transfer. The Optics Assembly Building is connected to the Laser and Target Area Building via a "clean corridor" to allow transfers without losing stringent cleanliness.

Support Facilities-The support facilities are upgrades to existing LLNL support facilities (e.g., B391 that housed the Nova Laser) to provide target receipt and inspection, small optics, electrical, and mechanical support. 
Laser System-The NIF laser system consists of 192 laser beams configured to illuminate the target surface with a specified symmetry, uniformity, and temporal pulse shape. The laser pulse will originate in the pulse generation system. This precisely formatted, low-energy pulse will be amplified in the amplifiers. To minimize spatial intensity fluctuations, each beam will pass through a pinhole in a spatial filter on each of the four passes through the amplifier and through a transport spatial filter.

The beam transport system directs each high-power laser beam to an array of ports distributed around the target chamber, where the frequency of the laser light will be tripled in frequency (to $0.35 \mu \mathrm{m}$ ), spatially modulated (by phase plates), and focused on the target. Systems will automatically control the alignment and the measurement of the power and energy of the beam. Beampath infrastructure systems include structural support and auxiliary systems that provide the stable platform and utilities required.

Target Experimental Systems-The target area includes the 10-m-diameter, lowactivation aluminum alloy vacuum chamber located in the heavily shielded target area of the Laser and Target Area Building. A target positioner precisely locates the fusion targets in the target chamber. The target chamber and the surrounding building structure will provide the primary and secondary confinement of radioactivity (e.g., $x$-rays, neutrons, tritium, and activation products). User-supplied diagnostics arranged around the target chamber will obtain the comprehensive test data. Structural, utility, and other systems will provide required maintenance (e.g., decontamination of components) support. The Environmental Protection System controls the tritium inventory.

Integrated Computer Control Systems-The integrated controls system monitors and controls the laser and target systems. This computer-based control system includes the hardware and software necessary to support NIF operations, including the supervisory control system, ancillary system controls, integrated timing system for experimental control of laser and diagnostic operations, data acquisition, safety interlocks, and area access control. The laser physics simulation and analysis systems are part of the integrated control system.

Assembly, Installation, and Refurbishment Equipment-The assembly, installation, and refurbishment equipment includes all equipment required for: line-replaceable unit transport and handling, optics assembly, preamplifier module maintenance equipment, auxiliary equipment, small optic processing, and metrology equipment. The assembly, installation, and refurbishment equipment is located in the Preamplifier Module Maintenance Area, the Optical Assembly Building, and the support facilities.

Laser and Target System Utilities-The laser and target system utilities provide the water systems for demineralized, low conductivity, domestic, tempered, chilled, hot, and fire water (but not the fire protection system). The facility has multiple vacuum systems and gas systems that supply argon, synthetic air, and compressed air. The electrical (inside the facilities) distribution and cabling systems are part of the utility system. 


\subsection{NIF Work Breakdown Structure}

The NIF Project Work Breakdown Structure (NWBS) is the administrative organizing element for the NIF Project and supporting program elements. It consists of Plant and Capital Equipment (PACE) funded Total Estimated Cost and Operations and Maintenance (O\&M) funded Other Project Cost and NIF Demonstration Program funded activities. Appendix B includes the NIF Project Summary NWBS. In the rebaselining of the schedule and cost estimate that occurred in Fiscal Year 2000, the NWBS was revised and updated. 


\section{Management Roles and Responsibilities}

The Secretary of Energy has delegated to the Deputy Secretary the role of Acquisition Executive for the NIF Project. The Deputy Secretary approves all critical decisions. The NNSA Administrator and the Deputy Administrator for Defense Programs have full responsibility for all NIF Project decisions not specifically retained by the Acquisition Executive. The Deputy Administrator for Defense Programs will oversee the strategy and role of the NIF in the Stockpile Stewardship Program.

Overall DOE/NNSA management responsibilities were first stated in the approved Project Charter ${ }^{9}$ signed in March 1993. Since then, the Defense Programs Office of the NIF Project ${ }^{10}$ was established to interpret, explain, and defend the role of the NIF Project and provide executive-level Project control for Defense Programs. More recently, part of the NNSA's Office of Research and Inertial Fusion has been combined with the Office of the NIF under a single Director at NNSA Defense Programs headquarters with a Deputy Director/Field Manager at the Livermore site.

\subsection{Deputy Administrator, NNSA Defense Programs}

The NNSA Deputy Administrator for Defense Programs, is responsible for the NNSA roles for formulating policy and overall direction, budget authorization, and for interfacing with the National ICF Program and the Stockpile Stewardship Program. The Deputy Administrator reports directly to the NNSA Administrator and will:

- Chair the NIF Level 1 BCCB to coordinate the NNSA decisions on all proposed baseline changes that are within the Level 1 approval thresholds or decision points (as identified in Tables 4-1 and F-1).

- Provide authority for the disposition of Level 1 Baseline Change Proposals (BCPs).

- Interface with the Level 0 BCCB.

- Establish and implement the Project policy through the Project Charter, ${ }^{9}$ Justification of Mission Need, ${ }^{1}$ and this Project Execution Plan.

- Review and coordinate the approval of NNSA-controlled baselines, and initiate critical decision and other required reviews.

- Maintain a close interface with Stockpile Stewardship user groups and with Energy and Science Program users.

\subsection{Director, NNSA Office of the NIF Project}

The Defense Programs Director, Office of the NIF Project, is responsible for the NNSA roles for formulating policy and overall direction, budget authorization, and interfacing with the National ICF Program and the Stockpile Stewardship Program. The Director reports directly to the NNSA Deputy Administrator for Defense Programs and will:

- Chair the NIF Level 2 BCCB to coordinate the NNSA decisions on all proposed baseline changes that are within the Level 2 approval thresholds or decision points (as identified in Tables 4-1 and F-1). 
- Establish and implement the Project policy through the Project Charter, ${ }^{9}$ Justification of Mission Need, ${ }^{1}$ and this Project Execution Plan.

- Be responsible for NNSA Program Management for all research and development programs supporting the NIF Project.

- Establish the Project review process and ensure that independent reviews are conducted.

- Secure resources, issue Project Work Authorizations, and overall formal Project and technical guidance and direction. Review the status of technical, cost, and schedule performance of the Project.

- Review and coordinate the approval of NNSA-controlled baselines and initiate critical decision and other required reviews.

- Maintain a close interface with Stockpile Stewardship user groups and with Energy and Science Program users.

\subsection{Defense Programs, Deputy Director, Office of the NIF Project/Field Manager}

The Defense Programs Deputy Director, Office of the NIF Project/Field Manager, is responsible for the formal day-to-day onsite Project interface and monitoring. The Deputy Director/Field Manager reports functionally to the Director of the Office of the NIF Project and administratively to the DOE Oakland Operations Office (OAK) and will:

- Provide NNSA on-site Project management, including monitoring all aspects of the Project phases relative to the technical, cost, and schedule baselines and ensuring the adequacy of the Project management system.

- Be responsible for NNSA on-site management of all research and development programs supporting the NIF Project.

- Provide the DOE/NNSA oversight over all NIF-related ES\&H requirements including Integrated Safety Management (ISM) system implementation.

- Act as the backup Chairperson to the Director of the Office of the NIF Project for the NIF Level 2 BCCB.

- Coordinate with DOE and NNSA Field matrix organizations, as required, to obtain support for Project management activities.

- Function as the formal communications channel between the NIF Project Office and DOE/NNSA headquarters; apprising the Director, Office of the NIF Project, of any Project-related issues.

- Develop, monitor, and evaluate performance against the contract measures for the NIF.

- Participate and provide guidance in the NIF Project Office Level 3 BCCB when necessary.

\subsection{Director, Lawrence Livermore National Laboratory}

The Laboratory Director is responsible for administration of NIF Programs and for oversight of the NIF Project. 
The Director reports functionally to the NNSA Deputy Administrator for Defense Programs and administratively to the Regents of the University of California and will:

- Provide administrative leadership for the NIF ensuring resolution of institutional infrastructure, organization interfaces and priorities within the Laboratory

- Interface with the Senior NNSA management on NIF oversight and status

- Appoint the Associate Director for NIF Programs (line manager) responsible for the NIF Project and the supporting ICF Program.

- In addition to laboratory internal oversight, appoints a NIF Program Review Committee to perform independent reviews of project strategy, status, and issues.

- Ensure review results and recommendations are reported to the U.C. Regents, and the NNSA.

- Interface with the Stockpile Stewardship management community.

\subsection{Associate Director for NIF Programs}

The Associate Director for NIF Programs is responsible for both the NIF Project and the ICF Program. Provides senior institutional management of the LLNL NIF Programs. The Associate Director for NIF Programs reports functionally to the Defense Programs Office of the NIF Project and administratively to the LLNL Laboratory Director and will:

- Provide executive-level representation of the NIF Project/LLNL ICF Program to NNSA offices, other agency and government leaders, and the private sector.

- Interface with the NIF Program Review Committee (PRC), composed of individuals selected for their expertise and experience relevant to each of the Project phases, to obtain independent and critical review of and advice on all Project aspects.

- Provide senior institutional management and coordination of the NIF Project and the ICF Programs

- Provide liaison with the University of California (UC) Office of the President and the LLNL Laboratory Director to ensure strong oversight of the NIF Project.

- Interface with the Stockpile Stewardship user community and energy and science users.

\subsection{NIF Project Manager}

The NIF Project Manager is responsible for implementing the Project and directing the participants. The NIF Project Manager reports to the Associate Director for NIF Programs and will:

- Chair the Level 3 BCCB to coordinate Project decisions on all proposed baseline changes that are within the Level 3 approval thresholds or decision points (as identified in Tables 4-1 and F-1).

- Execute the Project and direct the participating laboratories and industrial contractors such as architect engineers, construction managers/general contractors, equipment vendors, and other industrial firms. 
- Be responsible for all research and development programs required to successfully complete the NIF Project.

- Monitor progress and effect necessary corrective actions, where required, to resolve problems and conflicts that affect Project implementation.

- Interface with the NNSA Director, Office of the NIF Project, and the Deputy Director/NIF Field Manager.

- Establish and maintain baselines (technical, cost, and schedule) in accordance with this Project Execution Plan, and report their status to the NNSA in a timely and accurate manner.

- Ensure industry involvement in the implementation of the NIF by providing for the contracting, management, and technical direction (as the Contracting Officer's Technical Representative) of the Architect/Engineers, Engineering Support Contractors, the Integration Management and Installation Contractor, and other contractors/vendors.

- Implement, utilizing the principles of the ISM system, applicable ES\&H requirements; quality assurance; and security in the design, construction, and activation of NIF.

\subsection{Institutional Deputy Project Managers}

The Institutional Deputy Project Managers are responsible for supporting the NIF Project Manager in the Project implementation while representing their institutions. The Institutional Deputy Project Managers will:

- Represent their institutions on the Project and at their institution in terms of resource allocation, priority, and conflict resolution.

- Plan, direct, and control assigned Project responsibilities.

- Provide input to cost, schedule, and technical reporting for their assigned areas of responsibility.

- Execute their assurance responsibilities, incorporating ISM principles for ES\&H, quality assurance, and security.

Figure 3-1 depicts the NIF functional Project line management structure for the primary participants. 
Secretary of Energy

Deputy Secretary of Energy

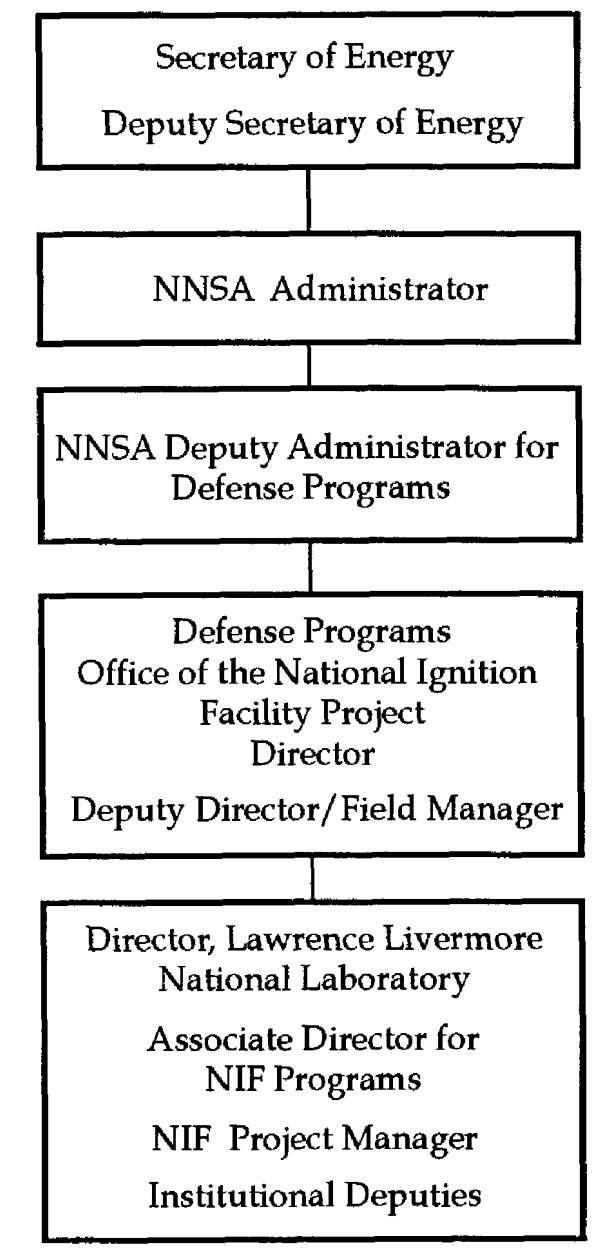

40-00-0494-1621pb09

Figure 3-1. NIF functional Project management structure. 


\section{Project Execution}

This chapter describes the management processes that will be used to implement the NIF Project. The NIF Project work logic diagram, which represents the progression of Project activities, is shown in Appendix C.

\subsection{Baseline Establishment}

The technical, cost, and schedule baselines for the NIF are formally established in this Project Execution Plan and provide the basis from which all proposed future changes are measured. The baseline schedule and cost estimates for the path forward have been approved by the Level $0 \mathrm{BCCB}$ after an independent validation review. This revision of the Project Execution Plan reflects the latest Project cost and schedule baseline approved by the Acquisition Executive. This document will be revised to reflect any future changes once they are approved through the established BCCB process. A summary of the current baseline data is contained in the NIF Project Data Sheet (see Appendix D), NIF Project Baseline costs (Appendix E) and Integrated Project Schedule (see Appendix F).

\subsubsection{Technical Baseline}

The approved NIF technical baseline is currently documented in the Justification of Mission Need Statement, ${ }^{1}$ NIF Functional Requirements and Primary Criteria (Appendix J), ${ }^{6}$ system design requirements, subsystem design requirements, and interface control documents.

The complete hierarchy of criteria and their relationship is shown in Figure 4-1. As detail design is accomplished, more system design requirements, interface control documents, and design media in the form of top-level drawings, calculations, and specifications will be formulated. In addition, key approved environmental and safety documents (e.g., the SSMPEIS ${ }^{5}$ and Preliminary Safety Analysis Report (PSAR) ${ }^{11}$ ) augment the baseline, as will the Final Safety Analysis Report (FSAR) ${ }^{12}$ and Draft Supplemental Environmental Impact Statement (DEIS) ${ }^{13}$ when the latter two documents are completed and approved.

\subsubsection{Cost Baseline}

The initial NIF cost baseline was based on the NIF Conceptual Design Report ${ }^{14}$ cost estimate, with associated profiles of budget authorization and outlay. This baseline was updated and revalidated with an Independent Cost Estimate Review at the completion of Title I Design, and approved by the Acquisition Executive (Level 0 BCCB) in March 1997. In September 2000, the Level 0 BCCB approved a total rebaseline of the NIF cost and schedule baselines (note: technical baseline unaffected). The updated Project Data Sheet contains the funding profile and is the basis for the approved baseline cost plan (see Appendix E). 


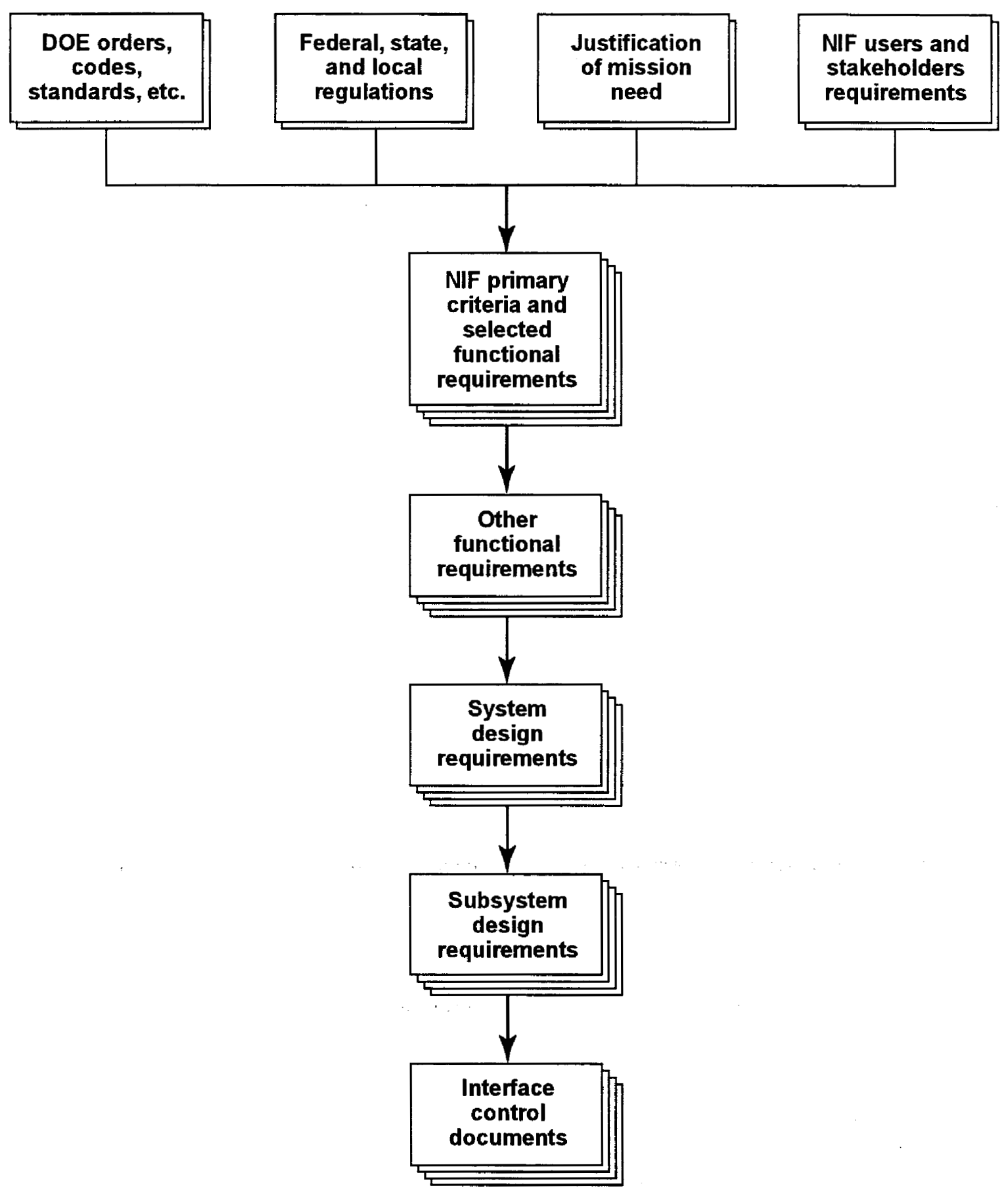

40-00-0494-1775pb05

Figure 4-1. Relational hierarchy of criteria. 


\subsubsection{Schedule Baseline}

Appendix F contains the NIF Summary Integrated Project Schedule, Major Milestones, and Critical Decisions (see Figure F-1).

\subsection{Baseline Change and Contingency Control}

Establishment and maintenance of baselines are important aspects of Project control. Changes to baselines will be carefully controlled to avoid loss of validity and distortion in performance reporting. The purposes of the Project change control system are to assure that:

- The cost, schedule, and technical impacts of proposed changes are developed and considered by all appropriate parties.

- The evaluations, produced by the appropriate parties, are considered in the approval or rejection of the proposed changes.

- Appropriate parties are informed of proposed changes and their disposition.

- Baseline documentation is controlled and updated as appropriate to reflect approved changes.

- Action on all change requests is deliberate and without undue delay, but carried out without interfering disproportionately with Project progress.

\subsubsection{Baseline Change Control and Configuration Control}

Technical, cost, and schedule baselines established upon approval of this Project Execution Plan are subject to the Baseline Change Control Board (BCCB) review process. BCCBs will be established at four levels $(0,1,2$, and 3$)$ to approve, disapprove, or endorse (i.e., recommend approval to a higher-level $B C C B$ ) all proposed baseline changes. The Energy Systems Acquisition Advisory Board (ESAAB) provides advice, assistance, and recommendations on critical decision points to the DOE Acquisition Executive. The ESAAB will be the Board to consider changes to the baseline, presented in the form of Baseline Change Proposals (BCPs), within the Acquisition Executive Level 0 Authority.

The change board hierarchy is shown in Figure 4-2, and change thresholds are listed in Table 4-1. Each lower-level board that approves a baseline change will provide the next higher-level board with a copy of the approved baseline change package and will endorse all proposed changes to be considered by the next higher-level board. This process ensures proper oversight of all proposed changes, which can originate at any level in the Project.

Membership of the Level 1, Level 2, and Level 3 BCCBs will be at the discretion of the respective board chairpersons. Authority and responsibilities of each board are to be defined in its decision-making charter. The Level 1, Level 2, and Level 3 BCCB Chairpersons shall have full decision-making authority; the boards are advisory rather than voting boards. The Chairperson of each board, at his or her discretion, may provide disposition of a requested change without conducting a board meeting. The Vice Chairperson of the Level 2 BCCB will be notified of and may participate in all Level 3 BCCB meetings. 
Figure 4-2. Baseline Change Control Board (BCCB) hierarchy.

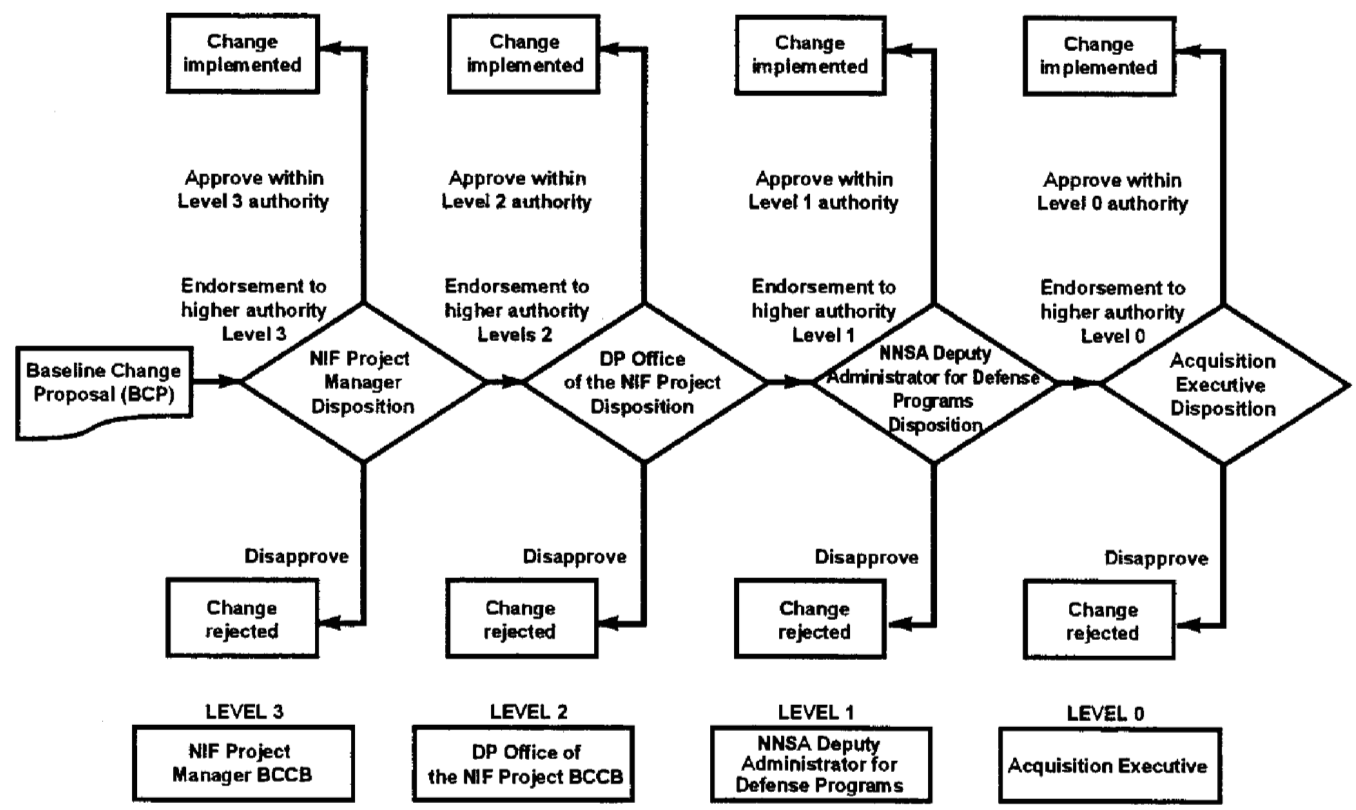

40-00-0495-1039pb09c

$7 / 27 / 00$ aeh 
Table 4-1. Baseline Change Control Thresholds.

\begin{tabular}{|c|c|c|c|c|}
\hline & $\begin{array}{l}\text { Acquisition } \\
\text { Executive } \\
\text { (Level 0) }\end{array}$ & $\begin{array}{l}\text { NNSA Deputy } \\
\text { Administrator for } \\
\text { Defense Programs } \\
\text { (Level 1) }\end{array}$ & $\begin{array}{l}\text { DP Director, } \\
\text { Office of the NIF } \\
\text { (Level 2) }\end{array}$ & $\begin{array}{l}\text { NIF Project Manager } \\
\text { (Level 3) }\end{array}$ \\
\hline $\begin{array}{l}\text { Technical } \\
\text { (Scope) } \\
\text { Baseline } \\
\text { Threshold }\end{array}$ & $\begin{array}{l}\text { - Any change } \\
\text { to scope that } \\
\text { affects } \\
\text { Justification } \\
\text { of Mission } \\
\text { Need. }\end{array}$ & $\begin{array}{l}\text { - Changes to } \\
\text { scope that affect } \\
\text { operations } \\
\text { functions but } \\
\text { not the } \\
\text { Justification of } \\
\text { Mission Need. }{ }^{1} \\
\text { - Any deviation } \\
\text { from the } \\
\text { primary criteria } \\
\text { and selected } \\
\text { functional } \\
\text { requirements. }\end{array}$ & $\begin{array}{l}\text { Any deviation in } \\
\text { functional } \\
\text { requirements } \\
\text { other than } \\
\text { selected } \\
\text { functional } \\
\text { requirements. }\end{array}$ & $\begin{array}{l}\text { Any change in } \\
\text { System Design } \\
\text { Requirements that } \\
\text { affect system } \\
\text { performance. }\end{array}$ \\
\hline $\begin{array}{l}\text { Schedule } \\
\text { (Milestone) } \\
\text { Baseline } \\
\text { Threshold }\end{array}$ & $\begin{array}{l}\text { Changes to } \\
\text { Level } 0 \\
\text { milestones in } \\
\text { excess of six } \\
\text { months. }\end{array}$ & $\begin{array}{l}\text { - Changes to } \\
\text { Level } 0 \\
\text { milestones of } \\
\text { less than six } \\
\text { months. } \\
\text { - Changes to } \\
\text { Level 1 } \\
\text { milestones in } \\
\text { excess of six } \\
\text { months. }\end{array}$ & $\begin{array}{l}\text { - Changes to } \\
\text { Level } 1 \\
\text { milestones of } \\
\text { less than six } \\
\text { months. } \\
\text { - Changes to } \\
\text { Level } 2 \\
\text { milestones in } \\
\text { excess of six } \\
\text { months. }\end{array}$ & $\begin{array}{l}\text { - Changes to Level } 2 \\
\text { milestones of less } \\
\text { than six months. } \\
\text { - Changes to Level } 3 \\
\text { milestones in } \\
\text { excess of six } \\
\text { months. }\end{array}$ \\
\hline $\begin{array}{l}\text { Cost } \\
\text { (Dollar) } \\
\text { Baseline } \\
\text { Threshold }\end{array}$ & $\begin{array}{l}\text { Any change } \\
\text { in Total } \\
\text { Project Cost } \\
\text { (TPC). }\end{array}$ & $\begin{array}{l}\text { - Any change in } \\
\text { Total Estimated } \\
\text { Cost (TEC) that } \\
\text { does not affect } \\
\text { the TPC. } \\
\text { - Changes greater } \\
\text { than } \$ 25 \mathrm{M} \text { that } \\
\text { do not affect the } \\
\text { TEC/TPC. } \\
\text { - Changes } \\
\text { requiring } \\
\text { modification of } \\
\text { the Project Data } \\
\text { Sheet Funding } \\
\text { Profile. }\end{array}$ & $\begin{array}{l}\text { - Changes less } \\
\text { than } \$ 25 \mathrm{M} \text { and } \\
\text { greater than } \\
\$ 10 \mathrm{M} \text { that do not } \\
\text { affect TEC/TPC. } \\
\text { - Changes } \\
\text { requiring } \\
\text { contingency } \\
\text { allocation of } \\
\text { more than } \$ 10 \mathrm{M} \text {. }\end{array}$ & $\begin{array}{l}\text { - Changes less than } \\
\$ 10 \mathrm{M} \text { that do not } \\
\text { affect the } \\
\text { TEC/TPC. } \\
\text { - Changes requiring } \\
\text { contingency } \\
\text { allocation up to } \\
\$ 10 \mathrm{M} \text {. }\end{array}$ \\
\hline
\end{tabular}

For directed changes, the NNSA-HQ (Level 1 or Level 2) directive will be the authorization for implementing the change. Directed changes do not require change board approval unless they impact the technical, cost, or schedule baseline. If the NIF Project Office determines an impact to the baselines, the impact will be submitted as a $\mathrm{BCP}$ for review by the appropriate $\mathrm{BCCB}$. 
If changes (either approved or directed) exceed congressionally mandated thresholds, congressional notification is required prior to approval and authorization to proceed. All congressional notifications will be coordinated through the DOE Chief Financial Officer prior to submission.

The NIF Project Office will control Project documents through the process of issuing, reviewing, and approving changes. These are the chief change- control processes for Project documents and are central to the NIF configuration control system, which will ensure that the Project documents are current with the actual as-installed NIF systems. The configuration control system is described in the NIF Configuration Management Plan $^{15}$ and the implementing Project procedures.

\subsubsection{Contingency Control}

Project contingency is the planned funds identified in the Plant-and-CapitalEquipment-funded NIF Total Estimated Cost and Other-Project-Cost-funded activities to cover unforeseeable but "in-scope" situations. Contingency was first established in the conceptual design process and documented in the NIF Conceptual Design Report. ${ }^{14}$ It was updated after the completion of Title I Design and again as part of the FY 2000 rebaselining. The established Project contingency can only be adjusted through the BCCB process.

For the NIF Project, allocations of contingency will be controlled through BCCB actions. For these changes, a master contingency log will be kept by the Level $3 \mathrm{BCCB}$ to record each allocation. Contingency will be monitored and controlled on a total Project basis. The Project manager will establish lower-level BCCBs, as appropriate, and will delegate certain levels of authority. Allocations of less than or equal to $\$ 500,000$ can be made without a BCCB meeting. Notification of these allocations will go to the next higher level change board.

Each year's PACE funded TEC and O\&M funded Other Project Cost appropriations will include a portion of the total Project contingency.

\subsection{NNSA Budget Authorization Process}

NIF funding requests are made as part of the NNSA annual budget request process, for inclusion in the Defense Programs' Corporate Review Budget, the Office of Management and Budget, and the Congressional budget submissions. An independent validation of the NIF annual budget request may be performed for each fiscal year for which funds are requested.

The NIF Project Manager must establish annual budget guidance for the Project participants based on the negotiated scope of work to be accomplished by each. This will yield the distributions recommended to the Office of the NIF Project. Funding distribution will be coordinated by the Office of the NIF Project.

After Congressional authorization/appropriation of NIF funds, the NNSA will distribute the NIF funds to the appropriate Operations Offices via the approved financial plan process. The Work Authorization System/Prime Contract Modification Process will be used by NNSA for the general authorization of funds for work at the participating laboratories. 


\subsection{Procurement and Contracting}

The NIF Project Acquisition Plan ${ }^{16}$ identifies NIF procurements and contracts and describes the estimated cost and schedule. A detailed annual commitment plan is developed by the NIF Project Office prior to the start of each fiscal year, or as otherwise required.

Procurement solicitation and award actions for the Project will be accomplished by a dedicated procurement team at LLNL that will be responsible for the NIF acquisitions. However, all the participating laboratories will be able to make procurements as needed in accordance with their prime contracts or cooperative agreements.

\subsection{Reviews}

\subsubsection{NNSA Status and Independent Reviews}

The NIF Project conducts periodic (e.g., monthly, quarterly) status reviews for Defense Programs as requested. These reviews are integral to the Project technical, schedule, and cost tracking and reporting processes. Independent Reviews may be conducted to address various aspects of the Project. Reviewers may include the Secretary of Energy Advisory Board (SEAB) task force, reviews commissioned by the Office of the NIF Project (e.g., safety reviews, cost validation reviews, Independent Cost Estimate reviews), the NIF Program Review Committee, the UC and other properly empowered bodies.

\subsubsection{NIF Program Review Committee (PRC)}

The NIF PRC is to advise the LLNL Laboratory Director on all aspects of the NIF Project during the remainder of its design, construction, and operations phases. The PRC written reports go directly to Defense Programs and the UC President's Office. The Defense Programs Office of the NIF must concur on the Project's proposed responses to PRC report findings. The NIF PRC will have four sub-committees to review:

- Policies, Procedures, and Governances.

- Project Performance.

- Technology.

- Target Physics.

\subsection{Performance Control and Reporting Systems}

Project control and reporting requirements are outlined in the Life-Cycle Asset Management Order ${ }^{17}$ and Construction Program Management Plan. ${ }^{18}$ These documents provide guidance for a graded approach to Project management to minimize overall Project cost and schedule risk. The Project control system is closely integrated with the baseline change control and work authorization processes and will provide the required status and variance analysis for the specified reporting period. Analysis will, as a minimum, be provided for cumulative cost and commitment or schedule variances that exceed $10 \%$ or $\$ 100,000$, whichever is greater, on an annual basis. The NIF Project uses this integrated Project control system to provide effective planning and reporting, as well as day-to-day management capabilities. This system will:

- Identify and organize all of the work scope required to complete the Project. 
- Provide the means to break the work scope into tasks, with a time-phased budget and resource plan.

- Report to the Office of the NIF Project at Level 2 of the NWBS.

- Measure and report actual costs and commitments against the approved task plans and established baselines.

- Report on cumulative Project Earned Value, including computed cost and schedule variances, for the overall Project, at NWBS Level 2 and for selected Level 3 elements.

- Generate and maintain the cost and schedule baseline estimates for the Project.

- Forecast future funding requirements.

- Provide the basis for Project budget submissions and validations.

- Monitor and control procurement and contracting activities and commitments.

- The Project shall maintain the ability to provide, information at NWBS Level 3 and below if requested.

\subsubsection{Control Systems}

Each month, based on the current month and cumulative data, the responsible Cost Account Manager will prepare a status report. If variance thresholds are exceeded, the status report will include a variance analysis. The variance analysis report will identify the nature of the variance, the cause of the variance, the expected impact on the Project, a recovery plan, and a current estimate-at-completion (EAC). ${ }^{+}$The NIF Project Office summarizes the variance reports and maintains an EAC (annual and total Project) for each Level 2 and selected Level 3 NWBS elements.

The schedule, which contains a critical path network, is maintained as a Project planning and measurement tool. The individual tasks in the network support the effort and budgets in the Cost Account Plans. At the end of every month, the responsible manager will provide a schedule update, including changes to planned activity durations, changes to planned start and completion dates, changes to actual start and completion dates, additions and deletions of activities, changes to logic, and changes to budget.

In the event of major changes in the Project scope, schedule, and/or funding profile, the Project may be rebaselined. Rebaselining consists of modifying plans for all or part of the NWBS to re-establish a valid performance measurement baseline. Rebaselining is managed to ensure that cost and schedule control is maintained during the rebaseline process. For example, a DOE-approved Transition Period Implementation Plan ${ }^{19}$ was used to define and track Project progress during the rebaselining process completed at the end of FY 2000. All changes to the baseline are subject to BCCB review and are documented.

\subsubsection{Reporting}

The NIF Project Office will be responsible for collecting, maintaining, and integrating sufficient information to satisfy all of the Project management reporting requirements.

\footnotetext{
'Estimate at Completion (EAC): Estimate to complete the Project or an individual WBS element; includes all costs incurred to date and the estimated costs for the remaining work required.
} 
Each Project participant shall maintain complete financial data at the NWBS levels appropriate for its assigned work. Monthly and cumulative planned versus actual costs and commitments, with annual estimates to complete, will be reported to the NIF Project Office each reporting period. At the same time, each participant shall also report monthly technical and schedule progress. The NIF Project Office will prepare and distribute monthly and quarterly reports to the Defense Programs based on the integration of monthly information using an Earned Value System approach. Variance reports will be provided on NWBS Level 2 and selected NWBS Level 3 elements for cumulative cost and commitment or schedule variances that exceed $10 \%$ or $\$ 100,000$, which ever is greater, on an annual basis. Annual and Total EAC will be reported on Level 2 and selected level 3 elements.

Monthly reports (prepared for October, November, January, February, April, May, July, and August) shall be transmitted from the NIF Project Manager to the NNSA Office of the NIF Project by the 25th working day after the end of the month.

Quarterly reports (prepared for October-December, January-March, April-June, and July-September) shall be transmitted by the 25th working day after the end of the last month of the quarter from the NIF Project Manager to the NNSA Office of the NIF Project. The Office of the NIF Project shall transmit the NIF Quarterly Reports to the NNSA Deputy Administrator for Defense Programs and other headquarter staff with the Director's assessment within five working days of receipt.

\subsection{Assurances}

The predominant assurance objective is that the NIF will be constructed and operated in a safe, secure, and environmentally-sound manner and will ensure the reliable performance of the test program. To achieve these top-level objectives, the Project established formal programs for quality assurance; security; and ES\&H protection. A NIF Policy (NIF Project Control Procedure 1.11, Integrated Safety Management (ISM) $)^{20}$ was prepared to describe how ISM (DOE Order P450.4) ${ }^{21}$ is implemented in the NIF Project. Several master plans have been prepared: a Quality Assurance Program Plan; ${ }^{22}$ a security plan; and an ESEH Management Plan. ${ }^{23}$ Key outputs of the assurance program include the Quality Assurance procedures, security procedures, Quality Assurance files, Acceptance Test Procedures, Operational Test Procedures, Preliminary Hazards Analysis, ${ }^{24}$ PSAR, ${ }^{11}$ Construction Safety Program, ${ }^{25}$ FSAR, ${ }^{12}$ DEIS, ${ }^{13}$ and environmental permits.

\subsubsection{Quality Assurance}

Project Quality Assurance has been planned and managed consistent with the NIF Quality Assurance Program Plan, ${ }^{22}$ prepared in accordance with DOE Order 5700.6C, Quality Assurance. ${ }^{26}$ Each phase of the Project may require significantly different quality assurance requirements; therefore, the Quality Assurance Program Plan ${ }^{22}$ and implementation procedures have been revised twice and will be revised as appropriate. Also, new requirements have been defined since the original WSS were placed in Contract 48 in 1997. A gap analysis will be performed (e.g. 10 CFR 830.120) and, if changes are required, a revision will be prepared. Any changes require the appropriate BCCB approval.

The Quality Assurance Program Plan ${ }^{22}$ identifies the quality assurance requirements and measures for controlling work on the Project. The Plan: 
- Provides the base requirements (e.g., preparation and control of criteria, control of procured items, nonconforming item disposition) in a phased manner to meet the Project's technical requirements.

- Initiates core quality assurance elements in a risk-based graded approach to mitigate or eliminate the risk of component or system failure.

- Provides the quality assurance basis to integrate individual activities or interface with related activities (e.g., target fabrication).

- Defines how DOE ISM system requirements (contained in DOE P450.4) ${ }^{21}$ are implemented in the Project.

- Provides a single Project document showing how all applicable NNSA and DOE quality assurance requirements will be met.

The Quality Assurance Program Plan 22 utilizes a graded approach in which levels of risk are assessed and then an appropriate level of quality assurance and control requirements established. Risk management for the Project began with the NIF Risk Management Plan. ${ }^{27}$ Risk Management evaluation and mitigation has been assigned to the Systems Engineering organization in the Project. They have established the Risk Management Working Group and will provide an updated Risk Management Plan ${ }^{27}$ as part of the System Engineering Management Plan currently under preparation.

\subsubsection{Environmental Safety and Health Planning}

The ES\&H Management Plan ${ }^{23}$ describes how the NIF Project ensures the health and safety of workers and protects the public and the environment. It describes the policy, responsibilities, and documented evaluations and regulatory approvals that have been obtained prior to the beginning of construction (e.g., PSAR, ${ }^{\mathrm{T}}$ Construction Safety Program, ${ }^{25}$ National Environmental Policy Act (NEPA) determination, and environmental permits) and then prior to operation (e.g., $F S A R_{,}^{12}$ readiness assessments, environmental permits). The plan describes each area (radiation protection, safety, environmental impact; e.g., waste generation, effluents, etc.) in a specific section.

The NIF ESEH Management Plan ${ }^{23}$ was approved by the NIF Project Manager and the Deputy Director of the Office of the NIF Project and is being implemented.

The NIF Project Control Procedure 1.11, Integrated Safety Management, ${ }^{20}$ documents how the project implements an ISM system (DOE P450.4) ${ }^{2 \mathrm{~T}}$ that integrates ES\&H activities.

\subsubsection{NEPA Determination and Site Selection}

The NIF is included as a section of the SSMPEIS. ${ }^{5}$ The Notice of Intent for the $S S M P E I S^{28}$ states that the NEPA document is sufficiently detailed to address site selection, construction, and operation of the NIF. The $R O D^{4}$ resulting from the SSMPEIS ${ }^{5}$ was issued in December 1996. As settlement to litigation from 38 NonGovernment Agencies led by the Natural Resources Defense Council, a DSEIS ${ }^{13}$ has been prepared and reviewed with Public meetings in December 1999. The final DEIS is being prepared, and is scheduled to lead to a ROD by the end of FY 2000.

With the SSMPEIS ${ }^{5}$ completed, a Mitigation Action Plan ${ }^{29}$ and a Pollution PreventionMaste Minimization Plan ${ }^{30}$ have been prepared to mitigate the environmental impacts presented in the SSMPEIS ${ }^{5}$ and the ROD. ${ }^{4}$ Also, the environmental monitoring 
program has prepared a baseline for the selected site, and the environmental permits for construction and operation are being obtained from the appropriate federal, state, and local agencies.

The following sequence outlines the activities required to allow Title II Design and site construction to proceed on schedule:

- The Notice of Intent of the SSMPEIS ${ }^{28}$ was published in the Federal Register in June 1995.

- Input and feedback on the issues to be considered in the SSMPEIS ${ }^{5}$ were obtained from public meetings, and the DOE has prepared an implementation plan that forms the basis for the preparation of the draft SSMPEIS.

- The NIF NEPA documentation was prepared as a separate volume of the SSMPEIS.

- The NIF Environmental Volume describes all of the environmental impacts of constructing and operating the NIF at the preferred and alternative sites. It also discusses the consequences of the "no action" alternative.

- The draft SSMPEIS ${ }^{5}$ was reviewed by the public and the comments were incorporated into a final SSMPEIS, which was issued for public review.

- Following completion of the final SSMPEIS, ${ }^{5}$ the DOE published a ROD $^{4}$ with LLNL as the chosen site. For the NIF, this ROD ${ }^{4}$ includes the programmatic decisions on purpose, need, and site selection. A positive decision on the Projectspecific analysis of the environmental impacts of NIF construction and operations allows for site preparation and building excavation to begin (after Critical Decision 3).

- Critical Decision 3 (Appendix I of this document) was issued on March 7, 1997, by DOE.

- The Mitigation Action Plan ${ }^{29}$ was issued and is used annually. The environmental permits required for construction are being obtained and the site characterization baseline will be frozen for the environmental monitoring program. Prior to operation, environmental permits required for operation will be obtained from the Environmental Protection Agency and state and regional authorities.

- As a result of litigation settlement, a DSEIS ${ }^{13}$ has been prepared. The Notice of Intent ${ }^{31}$ was published, and the DSEIS ${ }^{13}$ reference was reviewed with the Public in meetings at Livermore, California, and Washington, DC, in December 1999.

\subsubsection{Safety Documents}

The primary safety documents are the NIF ISM Policy, ${ }^{20}$ ESEH Management Plan, ${ }^{23}$ Functional Requirements and Primary Criteria (Sections 3-10), ${ }^{6}$ Preliminary Hazards Analysis, ${ }^{24}$ PSAR, ${ }^{11}$ Construction Safety Program, ${ }^{25}$ and the FSAR. ${ }^{12}$ In addition, Facility Safety Procedures, Integration Work Sheets, and appropriate Operational Safety Procedures will be prepared prior to operation. The NIF has been added to the site Emergency Plan. ${ }^{32}$ These documents fully implement the ISM (DOE P450.4). ${ }^{21}$ The $P S A R^{11}$ was completed in May 1996, approved by LLNL in September 1996, and received DOE OAK concurrence in October 1996.

The $P S A R,{ }^{11}$ started based on the conceptual design and completed during Title I Design, confirmed the facility hazard category to be low hazard, radiological, which 
was first established by the Preliminary Hazards Analysis. ${ }^{24}$ The $F S A R^{12}$ will be based on Title II Design and will be one of the key documents required for first-bundle operations and the Readiness Assessment.

\subsubsection{Construction Safety Program}

The Construction Safety Program, ${ }^{25}$ which defines safety and environmental requirements and controls at the construction site, was first issued in January 1997 and has been updated twice. It describes how the ISM guiding principles and core functions are applied to manage, monitor, and improve construction safety at the site. It is provided for compliance to each construction contractor in the bid package. Each contractor provides a site-specific safety plan, consistent with the Construction Safety Program ${ }_{25}^{25}$ approved by the NIF Project prior to starting work. The Construction Safety Program is implemented by the Integration Management and Installation Contractor with oversight by the NIF Project Office. Safety performance is formally audited quarterly by Defense Programs Office of the NIF. 


\section{Method of Accomplishment}

The NIF Project Office (consisting of LLNL, LANL, SNL, and UR/LLE and supported by competitively-selected contracts with Architect Engineering firms, an integration management and installation contractor, equipment and material vendors, and construction firms) prepares the design, procures equipment and materials, and performs conventional construction, safety, system analysis, and acceptance tests. DOE/NNSA will maintain oversight and coordination through the Defense Programs Office of the NIF Project. All activities are integrated through the guiding principles and five core functions of the DOE ISM system (DOE P450.4)

\subsection{NIF Execution}

\subsubsection{Conceptual and Advanced Conceptual Design}

The conceptual design was completed in May 1994 by the staff of the participating laboratories. Keller and Gannon contractors provided designs of the conventional facilities and equipment.

Design requirements were developed through a Work Smart Standards-Like Process ${ }^{7}$ approved by the Manager of the Oakland Operations Office. New requirements have been defined since the original WSS were placed in Contract 48 in 1997. A gap analysis will be performed and, if changes are required a revision will be prepared.

The Conceptual Design Report ${ }^{14}$ was subjected to an Independent Cost Estimate Review by Foster Wheeler USA under contract to the DOE. The advanced conceptual design phase further developed the design, and is the phase in which all the criteria documents that govern Title I Design were reviewed and updated.

\subsubsection{Title I Design}

In fiscal year 1996, Title I Design began with the contract award for the Architect/Engineers (Parsons and AC Martin) and a Construction Management firm (Sverdrup) for the design and the constructiblity reviews of the (1) NIF Laser and Target Area Building and (2) Optics Assembly Building. Title I Design included developing advanced design details to finalize the building and the equipment arrangements and the service and utility requirements, reviewing Project cost estimates and integrated schedule, preparing procurement plans, conducting design reviews, completing the PSAR ${ }^{11}$ and NEPA documentation, and planning for and conducting the constructibility reviews.

Title I Design was completed in November 1996 and was followed by an Independent Cost Estimate Review.

\subsubsection{Title II Design}

The participants in Title $\Pi$ (final design) include LLNL, LANL, SNL, RM Parsons, AC Martin, and Jacobs/Sverdrup (constructibility reviews). The Title II Design provides construction subcontract packages and equipment procurement packages, construction cost estimate and schedule, Acceptance Test Procedures and the acceptability criteria for tested components (e.g., pumps, power conditioning, special equipment), and 
National Ignition Facility Project Execution Plan Rev $2 a$

environmental permits and plans for construction (e.g., Storm Water Pollution Prevention Plan). ${ }^{33}$

\subsubsection{Title III Engineering}

The Title III Engineering participants include LLNL, Parsons, AC Martin, and Jacobs/Sverdrup. Title III Engineering represents the engineering necessary to support the construction and equipment installation, including inspection and field engineering. The main activities are to perform the engineering necessary to resolve issues that may arise during construction (e.g., fit problems, interferences, etc.). Title III Engineering will result in the final as-built drawings that represent the NIF configuration.

\subsubsection{Construction and Equipment Procurement, Installation, and Acceptance}

Based on the March 7, 1997, Critical Decision 3, construction began with site preparation and excavation of the LTAB forming the initial critical-path activities. The NIF Construction Safety Program (Section 4.7.2.3) was approved and sets forth the safety requirements at the construction site for all LLNL and non-LLNL (including contractor) personnel. There was sufficient Title II Design completed to support bid of the major construction and equipment procurements. The conventional facilities are designed as construction subcontract bid packages and competitively bid as firm fixed price procurements. The initial critical-path construction activities include both the Laser and Target Area Building and the Optics Assembly Building (where large optics assembly and staging will take place). In addition, the site support infrastructure needed to support construction of conventional facility, beampath infrastructure installation, and line replaceable equipment and optics staging are being put in place. At the same time, procurements on the critical path (e.g., target chamber) began following the established NIF Project Acquisition Plan. ${ }^{16}$ This plan is being updated to reflect the current acquisition strategy.

The next major critical path activity is the assembly and installation of the Beampath Infrastructure Systems. These are the structural and utility systems required to support the line replaceable units. The management and installation of the Beampath Infrastructure System is being contracted to an Integration Management and Installation Contractor. This was done to fully involve industry in the construction of NIF as directed in the Secretary of Energy's 6-Point Plan and recommended by the Secretary of Energy Advisory Board interim report in January $2000 .^{34}$ During the period of Beampath Infrastructure System installation, line replaceable unit and optics procurements continue.

The line replaceable unit equipment will be delivered, staged, and installed as phased beneficial occupancy of the Laser and Target Area Building is achieved. This is a complex period in which priority conflicts may occur because construction, equipment installation, and acceptance testing will be occurring. The Associate Project Managers, Area Integration Managers, and Integration Management and Installation Contractor will manage and integrate the activities to avoid potential interferences affecting the schedule. The construction, equipment installation, and acceptance testing will be supported by Title III inspection and field engineering, which will include resolving construction and installation issues and preparing the final as-built drawings. 


\subsubsection{Operational Testing and Commissioning}

After installation, the facility and equipment will be commissioned prior to the phased turnover to the operations organization. The transfer points employ the Management Pre-Start Review (MPR) process in which an independent team evaluates the readiness (e.g., training and qualification of operators, Commissioning Test Procedures results, as-built drawings, etc.) and recommends turn over by the NIF Project Manager. The NIF Project Manager approves the transfer of responsibility for ISMS Work Authorization.

The integrated system activation will begin with the commissioning of the first bundle. MPRs will be used by the Project Manager to control each system turnover. In specific cases, such as light propagation Phase 4 light to target bay, the DOE NNSA Field Office will concur in the MPR. A sequence of MPRs are scheduled (see Table F-1) to ensure a disciplined and controlled turnover of NIF systems from construction to activation. MPRs will be conducted by LLNL prior to the start of first experiments and NIF 192-beam operation, and the results will be validated by the Defense Programs Office of the NIF Readiness Assessment. The first experiment and 192-beam Readiness Assessment requires that the $F S A R^{12}$ be completed and approved (including the documented operating/maintenance procedures, operating staff training, and as-built design documentation). The 192 beam Readiness Assessment results are a key input for Critical Decision 4 (Project closeout) by the Acquisition Executive.

\subsubsection{Project Completion}

The complete set of NIF criteria is contained in the NIF Functional Requirements and Primary Criteria. ${ }^{6}$ These are the criteria that NIF is required to meet when fully operational. However, early test operation of NIF by the Program through a series of turnovers controlled by MPRs will be achieved by a phased transition to Program operations for user tests before Project completion. This enables the Program to begin experimental operations in support of Stockpile Stewardship and other programmatic missions at the earliest possible date, as NIF performance capability is building up toward the eventual goals set out in the NIF Functional Requirements and Primary Criteria. ${ }^{6}$ The Project Completion Criteria are documented in Appendix K.

\subsection{Security}

The operation of the NIF generates classified data requiring safeguarding; the Project itself represents a large investment of government funds in assets that must be protected. The Functional Requirements and the System Design Requirements identify security-system design requirements. A NIF First Experiments Security Plan will be prepared and submitted for OAK/NNSA Safeguards and Security Division Director approval prior to the first-bundle experimental operations. The plan will describe the NNSA requirements and compliance of the NIF design (e.g., access control, vaults, secure transfer lines, etc.) and administrative procedures that implement them. It will also describe the site security organization and interface to the NIF Project security team. Issues related to transparency of experimentation by the user community and international collaboration will be addressed in the final NIF Security Plan to be approved by the OAK/NNSA Safeguards and Security Division Director before Critical Decision 4. 


\section{Effective Date and Amendments}

This NIF Project Execution Plan will be implemented immediately upon approval. This approved plan is a controlled document and provides the Project baseline. All Project baseline revisions are subject to the BCCB system requirements as discussed in Chapter 4. Updated technical, schedule, and cost plans resulting from $B C C B$ decisions, as well as appendix changes of this document, may be appended to this plan without concurrence of the original approvers.

The initial Project Execution Plan required approval by the Secretary in his roll as Acquisition Executive. Subsequent revisions to the body of the document will require approval of the Deputy Administrator for Defense Programs. 


\section{References}

1. U.S. Department of Energy, National Ignition Facility Justification of Mission Need, NIF-0001653 (January 1993).

2. U.S. Department of Energy, The National Ignition Facility and Stockpile Stewardship letter, April 24, 2000.

3. U.S. Department of Energy, Critical Decision 2 Approval Letter for the National Ignition Facility, NIF-0007328 (October 1994).

4. U.S. Department of Energy, Record of Decision, NIF-0001345, (December 19, 1996).

5. U.S. Department of Energy, Stockpile Stewardship and Management Programmatic Environmental Impact Statement, DOE/EIS-0236 (September 1996).

6. National Ignition Facility Functional Requirements and Primary Criteria, Rev. 1.6, NIF-0001006, Lawrence Livermore National Laboratory (March 1996).

7. U.S. Department of Energy, Documentation for Work Smart Standards Applications, DOE Order G 450.3-1 (February 1997).

8. Functional Requirements and Primary Criteria for the National Ignition Facility, letter from Scott L. Samuelson to James M. Turner (April 29, 1997).

9. Project Charter for the National Ignition Facility Conceptual Design, NIF-LLNL-95599/L-20523 (March 1993).

10. Memorandum of Understanding Regarding the Relationship between the Office of the National Ignition Facility and the Office of Research and Inertial Fusion (March 1995).

11. Preliminary Safety Analysis Report, NIF-0034583, Lawrence Livermore National Laboratory (September 30, 1996).

12. Final Safety Analysis Report, NIF-0019661, Lawrence Livermore National Laboratory (March 31, 1999).

13. U.S. Department of Energy, Draft Supplemental Environmental Impact Statement, DOE/EIS-0236-SI (December 1999).

14. National Ignition Facility Conceptual Design Report, UCRL-PROP-117093, L-16973-1, Lawrence Livermore National Laboratory (May 1994).

15. National Ignition Facility Configuration Management Plan, Rev 1, NIF-0015684, Lawrence Livermore National Laboratory (October 1998).

16. National Ignition Facility Project Acquisition Plan, NIF-LLNL-796-251, Lawrence Livermore National Laboratory (April 1996).

17. U.S. Department of Energy, Life-Cycle Asset Management Order, DOE Order 430.1 (August 1995).

18. U.S. Department of Energy/Defense Programs, Construction Program Management Plan, Rev 0, Office of the Deputy Assistant Secretary for Research, Development and Simulation, DP-10 (June 1, 1999).

19. Transition Period Implementation Plan II, NIF-0049490, Lawrence Livermore National Laboratory (June 2000). 
20. National Ignition Facility Project Control Procedure 1.11, Integrated Safety Management, NIF-0018612-OC, Lawrence Livermore National Laboratory (June 2000).

21. U.S. Department of Energy, Integrated Safety Management System Guide, DOE Order P 450.4 (Novem ber 1997).

22. National Ignition Facility Quality Assurance Program Plan, Rev. 2, UCRL-ID-125435, Lawrence Livermore National Laboratory (June 1998).

23. National Ignition Facility Environmental Safety and Health Management Plan, NIFLLNL-95-599/L-20523, Lawrence Livermore National Laboratory (March 1996).

24. Preliminary Hazards Analysis, NIF-LLNL-93-125, Lawrence Livermore National Laboratory (October 1994).

25. Construction Safety Program, Rev. 2, NIF-0001321, Lawrence Livermore National Laboratory (July 30, 1999).

26. U.S. Department of Energy, Quality Assurance, DOE Order 5700.6C (May 1996).

27. NIF Risk Management Plan, UCRL-10126809, Rev. 1, NIF0001564-OB.

28. U.S. Department of Energy, Environmental Impact Statement for the Programmatic Environmental Impact Statement for Stockpile Stewardship and Management Notice of Intent, FR 31291, Federal Register (June 1995).

29. Mitigation Action Plan, NIF-0001726, Lawrence Livermore National Laboratory (February 1997).

30. Pollution Prevention/Waste Minimization Plan, NIF-0010575, UCRL-AR-131-194, Lawrence Livermore National Laboratory (September 1998).

31. U.S. Department of Energy, Supplemental Environmental Impact Notice of Intent, FR 98-25718, Federal Register (September 1998).

32. Emergency Plan, UCRL-MA-113311, Rev. 3 Vol. 3, Lawrence Livermore National Laboratory (May 1999).

33. Storm Water Pollution Prevention Plan, NIF-0003471-OC, Rev. 5, Lawrence Livermore National Laboratory (November 1999).

34. Interim Report of the National Ignition Facility Laser System Task Force, Lawrence Livermore National Laboratory (January 2000). 
Appendix A

Acronyms and Abbreviations 


\section{Acronyms and Abbreviations}

BCCB Baseline Change Control Board

BCP Baseline Change Proposal

DOE Department of Energy

DSEIS Draft Supplemental Environmental Impact Statement

EAC Estimate-at-completion

ESAAB Energy System Acquisition Advisory Board

ES\&H Environmental Safety and Health

FSAR Final Safety Analysis Report

ICF Inertial Confinement Fusion

ISM Integrated Safety Management

LANL Los Alamos National Laboratory

LLNL Lawrence Livermore National Laboratory

N.A Assembly, Installation, Refurbishment Equipment

N.C Integrated Computers and Controls

N.F Conventional Facilities

N.L.1 Main Laser System

N.L.2 Multiplexed Diagnostics

N.L.3 Laser Transport \& 3w Systems

N.L.4 Laser System Beam Control and Diagnostics

N.L.5 Laser System Integration

N.L.6 Laser System Optical Integration

N.M Management

N.T Target Experimental Systems

N.U Utilities

NEPA National Environmental Policy Act

NIF National Ignition Facility

NNSA National Nuclear Security Administration

NWBS NIF Project Work Breakdown Structure 
O\&M Operations and Maintenance

OAK Department of Energy Oakland Operations Office

PACE Plant and Capital Equipment

PRC Program Review Committee

PSAR Preliminary Safety Analysis Report

ROD Record of Decision

RTBF Readiness in Technical Base Facilities

SEAB Secretary of Energy Advisory Board

SEIS Supplemental Environmental Impact Statement

SNL Sandia National Laboratories

SSMPEIS Stockpile Stewardship and Management Programmatic Environmental Impact Statement

UC University of California

UR/LLE University of Rochester Laboratory for Laser Energetics 


\section{Appendix B}

NIF Work Breakdown Structure 
NIF Work Breakdown Structure

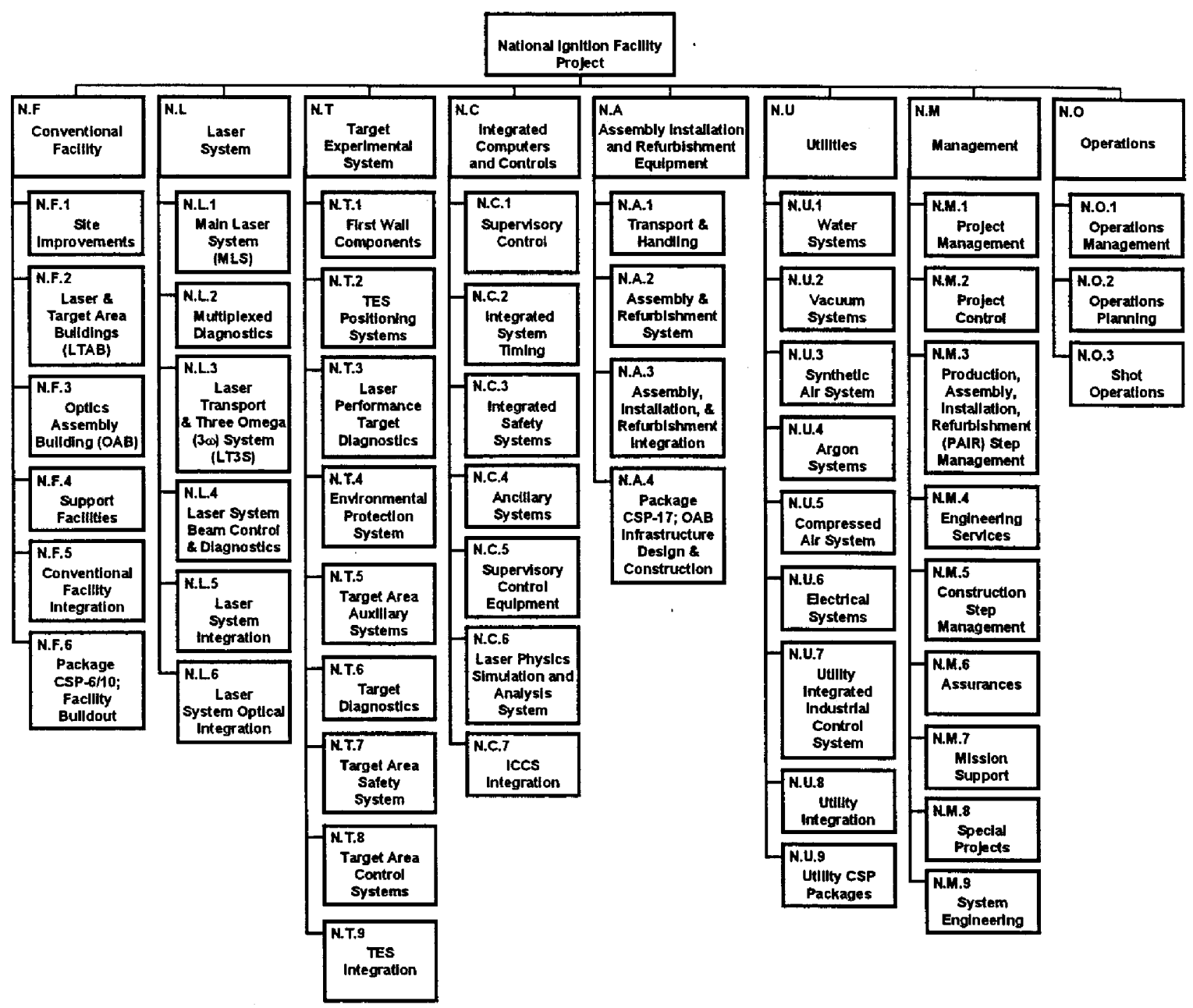

40-00-0700-5539pb01

Figure B-1. NIF Work Breakdown Structure. 


\section{Appendix C}

NIF Project Work Logic Diagram 


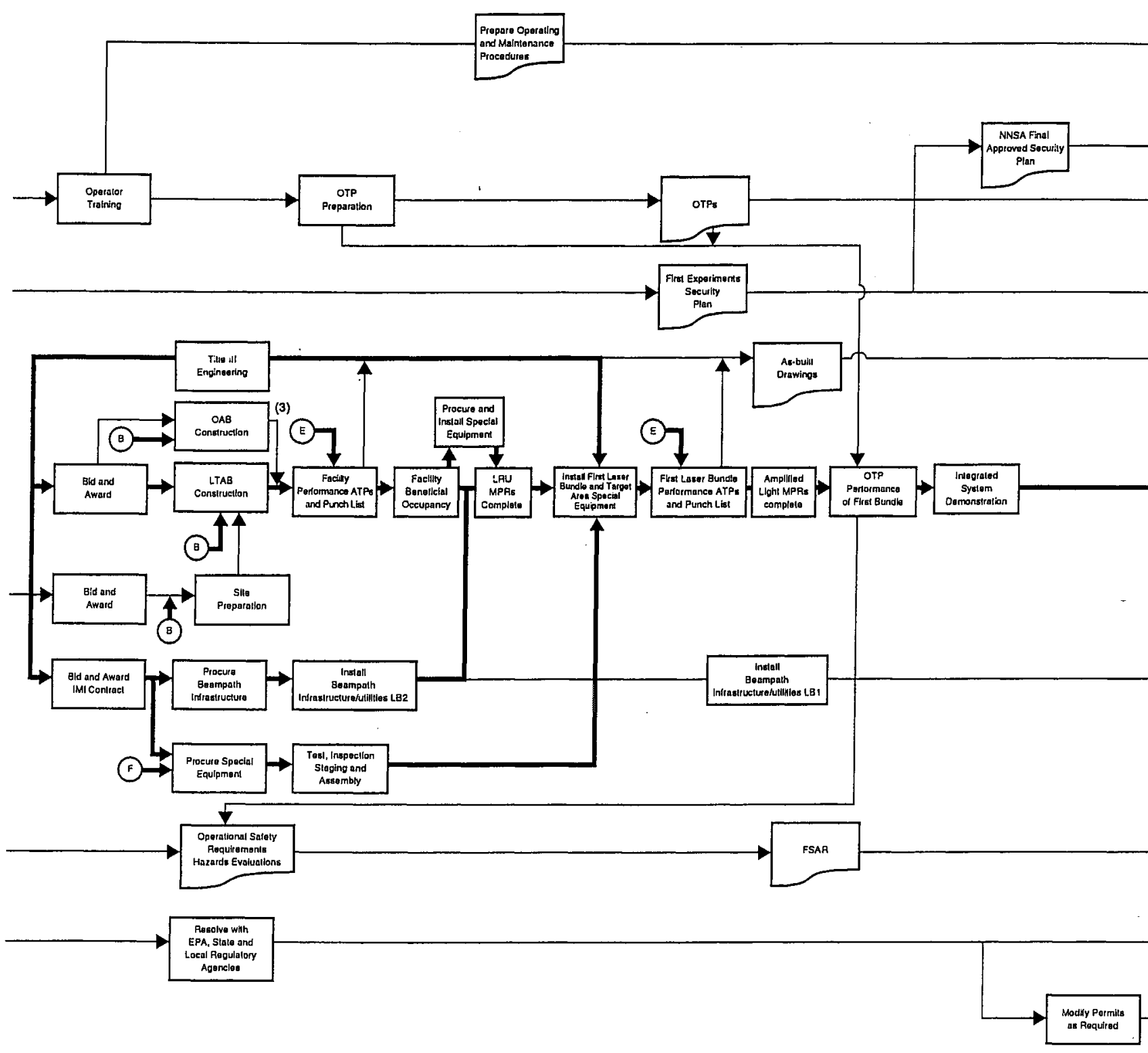

(3) $O A B$ and other Infrastructure 


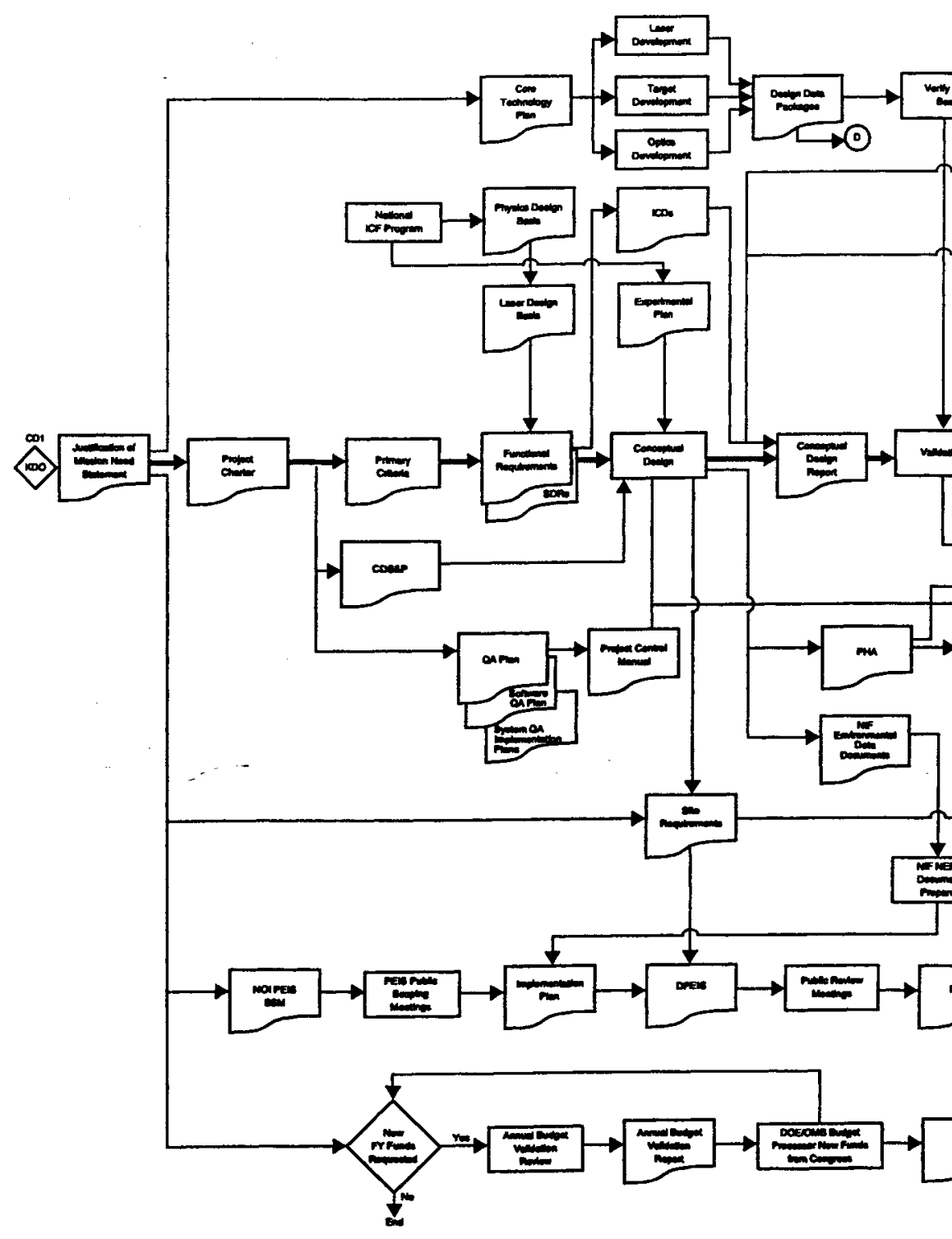


Appendix D

NIF Project Data Sheet 


\section{6-D-111, National Ignition Facility (NIF), Lawrence Livermore National Laboratory, Livermore, California}

(Changes from FY 2001 Congressional Budget Request are denoted with a vertical line [ 1$]$ in the left margin.)

\section{Significant Changes}

1. This revised Construction Project Data Sheet reflects the rebaselining action performed to meet the Secretary of Energy's commitment to provide the new NIF schedule and cost estimate to Congress by September 2000. In this replanning, there are no scope changes; the NIF Functional Requirements/Primary Criteria remain as approved in BCP 97-004. The changes to the schedule and cost estimate are mainly due to two factors: (1) The original contingency factors of $12 \%$ on Total Project cost (TPC) and $15 \%$ on Total Estimated Cost (TEC) were too low; (2) the complexity of the beampath infrastructure design and the necessity to assemble and install the laser system in clean environment were not fully appreciated and, as a result, the cost and schedule associated with this scope were seriously underestimated in the original baseline.

- The new NIF baseline:

- 1. Raises the contingency on the go-forward costs to $26.7 \%$ (of the remaining TEC BA) to a level commensurate with DOE guidelines and includes an assessment of risk for each element. This contingency is based on a "bottom-up" analysis that includes inputs from formal risk analysis, cost estimating uncertainty analysis, allowance for post-award change orders, industry standard allocations for conventional construction, project management assessments;

- 2. Incorporates the results of a comprehensive systems engineering analysis, which increased the cost estimates of beampath infrastructure construction and laser special equipment;

- 3. Changes the method of accomplishment to turn over completion of key implementation activities to experienced industrial firms consistent with the Secretary's directive. An Integration and Management Installation (IMI) contract has been submitted to DOE for approval;

- 4. Initiates a mission first strategy deployment strategy that maximizes the utility of the NIF for Stockpile Stewardship activities as early as possible during commissioning.

- These actions have resulted in the path forward for the project that increases the total cost of the project by approximately $\$ 1$ billion and extends the NIF completion date by five years to 2008 .

The funding amounts contained in this datasheet conform to the annual budget profile contained in the letter from the Secretary of Energy to Congress dated June 1, 2000. These amounts have been reviewed for project impact and execution during a recently completed rebaselining exercise. The rebaseline cost and schedule estimates have been validated by an independent DOE review team. 
1 - This datasheet changes the presentation of the costs for the National Ignition Facility to include not only the line item construction costs (TEC) and traditional Other Project Costs, but also the other related Operations and Maintenance costs that support NIF. These costs were funded from FY 1995 through FY 2000 within Lawrence Livermore National Laboratory's Inertial Confinement Fusion program. In the FY 2001 Budget Request, the funding is in Readiness in Technical Base and Facilities, and is specifically identified as NIF Operations and NIF Program Facilities and Infrastructure Buildup Activities. The activities supported with this funding are, and always have been, an integral part of the research and development program necessary to accomplish the advances in technology required to complete NIF, the largest and most complex optical unit ever to be designed and constructed. It includes the development of laser and optics technology, as well as the assembly, installation and activation of the Line Replaceable Units (the modules of the laser system) for all beams of NIF. The change from the amount assumed at the time of submission of the FY 2001 budget is due to the fact that there will now be research, development and support work associated with NIF through completion of the project in FY 2008. However, this does not represent an overall increase in funding during these years, since there would have been comparable costs for operating NIF from FY 2004 through FY2008. 


\section{Construction Schedule History}

\begin{tabular}{|c|c|c|c|c|c|c|c|}
\hline \multicolumn{3}{|c|}{ Fiscal Quarter } & $\begin{array}{c}\text { Total } \\
\text { Estimated } \\
\text { Cost } \\
(\$ 000)\end{array}$ & $\begin{array}{c}\text { Total } \\
\text { Project } \\
\text { Cost } \\
(\$ 000)\end{array}$ & $\begin{array}{c}\text { Other } \\
\text { Related } \\
\text { Costs } \\
(\$ 000)\end{array}$ & $\begin{array}{c}\text { Total } \\
\text { Project- } \\
\text { Related } \\
\text { Costs } \\
(\$ 000)\end{array}$ \\
\hline $\begin{array}{c}\text { A-E Work } \\
\text { Initiated }\end{array}$ & $\begin{array}{c}\text { A-E Work } \\
\text { Completed }\end{array}$ & $\begin{array}{c}\text { Physical } \\
\text { Construction } \\
\text { Start }\end{array}$ & $\begin{array}{c}\text { Physical } \\
\text { Construction } \\
\text { Complete }\end{array}$ & \begin{tabular}{c}
$(\$ 00)$ \\
\hline
\end{tabular}
\end{tabular}

FY 1996 Budget Request (Preliminary Estimate) . . . . (Title / Baseline) ....... 1Q 1996 1Q1998

FY 2000 Budget Request .. 1 Q $1996 \quad 2 Q 1998$

3Q $1997 \quad 3 Q 2002$

$842,600 \quad 1,073,600$

N/A N/A

FY 2001 Budget Request

(Current Baseline Estimate) $\quad 1 Q 1996 \quad 2 Q 1998 \quad 3 Q 1997$

FY 2001 Amended Budget
Request $\ldots \ldots \ldots \ldots \ldots \ldots \ldots$ 1Q $1996 \quad 201998 \quad 301997$

3Q 1997

3Q 2003

$1,045,700 \quad 1,198,900$

N/A

N/A

N/A

N/A

\section{Financial Schedule}

\section{(TEC Funding)}

(dollars in thousands)

\begin{tabular}{|c|c|c|c|}
\hline Fiscal Year & Appropriations & Obligations & Costs \\
\hline 1996 & 37,400 & 37,400 & 33,990 \\
1997 & 131,900 & 131,900 & 74,294 \\
1998 & 197,800 & 197,800 & 165,389 \\
1999 & 284,200 & 284,200 & 251,476 \\
2000 & $247,158^{\mathrm{b}}$ & 247,158 & 240,600 \\
2001 & 209,100 & 209,100 & 308,370 \\
2002 & 245,000 & 245,000 & 254,960 \\
2003 & 187,200 & 187,200 & 196,580 \\
2004 & 150,000 & 150,000 & 136,250 \\
2005 & 130,000 & 130,000 & 128,590 \\
2006 & 130,000 & 130,000 & 130,240 \\
2007 & 130,000 & 130,000 & 145,370 \\
2008 & 15,139 & 15,139 & 28,788
\end{tabular}

${ }^{a}$ The Other Related Costs show an increase of $\$ 366.9$ million. A similar amount would have been spent under the original estimate for operation of the completed facility. Therefore, for fiscal years 2004 to 2008 , there is no expected increase in total funding for NIF Other Related Costs. (See Significant Changes for more detail.)

${ }^{b}$ Original appropriation was $\$ 248,100,000$. This was reduced by $\$ 942,000$ for the FY 2000 rescission enacted by P.L. 106-113. 


\section{Project Description, Justification and Scope}

I The Project provides for the design, procurement, construction, assembly, and acceptance testing of the National Ignition Facility. The NIF is an experimental inertial confinement fusion facility intended to achieve controlled thermonuclear fusion in the laboratory by imploding a small capsule containing a mixture of the hydrogen isotopes, deuterium and tritium. The NIF is being constructed at the Lawrence Livermore National Laboratory (LLNL), Livermore, California as determined by the Record of Decision made on December 19, 1996, as a part of the Stockpile Stewardship and Management Programmatic Environmental Impact Statement (SSM PEIS).

The mission of the National Inertial Confinement Fusion (ICF) program is to execute high energy density physics experiments for the Stockpile Stewardship program, an important part of which is the demonstration of controlled thermonuclear fusion in the laboratory. Technical capabilities provided by the ICF program also contribute to other DOE missions including nuclear weapons effects testing and the development of inertial fusion power. As a key element of the Stockpile Stewardship Program, the NIF is designed to achieve propagating fusion burn and modest (1-10) energy gain within 2-3 years of full operation and to conduct high energy density experiments, both through fusion ignitions and through direct application of the high laser power. This mission was identified in the NIF Justification of Mission Need, which was endorsed by the Secretary of Energy. Identification of target ignition as the next important step in ICF development for both defense and non-defense applications is consistent with the earlier (1990) recommendation of DOE's Fusion Policy Advisory Committee, and the National Academy of Sciences Inertial Fusion Review Group. In 1995, the DOE's Inertial Confinement Fusion Advisory Committee affirmed the program's readiness for an ignition experiment. A review by the JASONs in 1996 affirmed the value of the NIF for stockpile stewardship.

The NIF project supports the DOE mandate to maintain nuclear weapons science expertise required for stewardship of the stockpile. After the United States announcement of a moratorium on underground nuclear tests in 1992, the Department established the Stockpile Stewardship program to ensure the preservation of the core intellectual and technical competencies in nuclear weapons. The NIF is one of the most vital facilities in that program. The NIF will provide the capability to conduct laboratory experiments to address the high energy density and fusion aspects that are important to both primaries and secondaries in stockpile weapons.

At present, the Nation's computational capabilities and scientific knowledge are inadequate to ascertain all of the performance and safety impacts from changes in the nuclear warhead physics packages due to aging, remanufacturing, or engineering and design alterations. Such changes are inevitable if the warheads in the stockpile are retained well into this century, as expected. In the past, the impacts of such changes were evaluated through nuclear weapon tests. Without underground tests, we will require better, more accurate computational capabilities to assure the reliability and safety of the nuclear weapons stockpile for the indefinite future.

To achieve the required level of confidence in our predictive capability, it is essential that we have access to near-weapons conditions in laboratory experiments. The importance of nuclear weapons to our 
national security requires such confidence. For detonation of weapon primaries, that access is provided in part by hydrodynamic testing. For secondaries and for some aspects of primary performance, the NIF will be a principal laboratory experimental physics facility.

The most significant potential commercial application of ICF in the long term is the generation of electric power. Consistent with the recommendations of the Fusion Policy Advisory Committee, the NIF will provide a unique capability to address critical elements of the inertial fusion energy program by exploring moderate gain $(1-10)$ target designs, establishing requirements for driver energy and target illumination for high gain targets, and developing materials and technologies useful for civilian inertial fusion power reactors.

The ignition of an inertial fusion capsule in the laboratory will produce extremely high temperatures and densities in matter. Thus, the NIF will also become a unique and valuable laboratory for experiments relevant to a number of areas of basic science and technology (e.g., stellar phenonena).

The NIF is an experimental fusion facility consisting of a laser and target area, and associated assembly and refurbishment capability. The laser will be capable of providing an output pulse with an energy of 1.8 megajoules (MJ) and an output pulse power of 500 terawatts (TW) at a wavelength of 0.35 micrometers $(\mu \mathrm{m})$ and with specified symmetry, beam balance and pulse shape. The NIF design is an experimental facility housing a multibeam line, neodymium (Nd) glass laser capable of generating and delivering the pulses to a target chamber. In the target chamber, a positioner will center a target containing fusion fuel, a deuterium-tritium mixture, for each experiment.

The NIF experimental facility, titled the Laser and Target Area Building, will provide an optically stable and clean environment. This Target Area Building will be shielded for radiation confinement around the target chamber and will be designed as a radiological, low-hazard facility capable of withstanding the natural phenomena specified for the LLNL site. The baseline facility is for one target chamber, but the design shall not preclude future upgrade for additional target chambers.

The NIF project consists of conventional and special facilities.

- Site and Conventional Facilities include the land improvements (e.g., grading, roads) and utilities (electricity, heating gas, water), as well as the laser building, which has an approximately 20,300 square meters footprint and 38,000 square meters in total area. It is a reinforced concrete and structural steel building that provides the vibration-free, shielded, and clean space for the installation of the laser, target area, and integrated control system. The laser building consists of two laser bays, each 31 meters $(\mathrm{m})$ by $135 \mathrm{~m}$ long, and a central target area--a heavily shielded $(1.8 \mathrm{~m}$ thick concrete) cylinder $32 \mathrm{~m}$ in diameter and $32 \mathrm{~m}$ high. The laser building includes security systems, radioactive confinement and shielding, control rooms, supporting utilities, fire protection, monitoring, and decontamination and waste handling areas. Optics assembly and refurbishment capability is provided for at LLNL by incorporation of an optics assembly area attached to the laser building and minor modifications of other existing site facilities.

Special facilities include the Laser System, Target Area, Integrated Computer Control System, and Optics. 
- The laser system is designed to generate and deliver high power optical pulses to the target chamber. The system consists of 192 laser beams configured to illuminate the target surface with a specified symmetry, uniformity, and temporal pulse shape. The laser pulse originates in the pulse generation system. This precisely formatted low energy pulse is amplified in the main amplifier. To minimize intensity fluctuation, each beam is passed through a pinhole in a spatial filter on each of the four passes through the amplifier and through a transport spatial filter. The beam transport directs each high power laser beam to an array of ports distributed around the target chamber where the frequency of the laser light is tripled to $0.35 \mu \mathrm{m}$, spatially modulated and focused on the target. Systems are provided for automatic control of alignment and the measurement of the power and energy of the beam. Structural support and auxiliary systems provide the stable platform and utilities required.

- The target area includes a $10 \mathrm{~m}$ diameter, low activation (i.e., activated from radiation) aluminum vacuum chamber located in the Target Area of the laser building. Within this chamber, the target will be precisely located. The chamber and building structure provide confinement of radioactivity (e.g., $\mathrm{x}$-rays, neutrons, tritium, and activation products). Diagnostics will be arranged around the chamber to demonstrate subsystem performance for project acceptance tests. Structural, utility and other support systems necessary for safe operation and maintenance will also be provided in the Target Area. The target chamber, the target diagnostics, and staging areas will be capable of conducting experiments with cryogenic targets. The Experimental Plan indicates that cryogenic target experiments for ignition will be needed 2-3 years after completion of the project. Therefore, the targets and this cryogenic capability will be supplied by the experiments. The NIF project will make mechanical and electrical provisions necessary to position and align the cryogenic targets within the chamber. The baseline is for indirectly driven targets. An option for future modifications to permit directly driven targets is included in the design.

- The integrated computer control system includes the computer systems (note: no individual computer will cost over $\$ 100,000$ ) required to control the laser and target systems. The system will provide the hardware and software necessary to support initial NIF acceptance and operations checkout. Also included is an integrated timing system for experimental control of laser and diagnostic operations, safety interlocks, and personnel access control.

- Thousands of optical components will be required for the 192 beamlet NIF. These components include laser glass, lenses, mirrors, polarizers, deuterated potassium dihydrogen phosphate crystals, potassium dihydrogen phosphate crystals, pulse generation optics, debris shields and windows, and the required optics coatings. Optics includes quality control equipment to receive, inspect, characterize, and refurbish the optical elements. 


\section{Project Milestones:}

Major milestones and critical decision points have changed as follow:

\begin{tabular}{|c|c|c|}
\hline Milestones & $\begin{array}{c}\text { Current } \\
\text { Date }\end{array}$ & $\begin{array}{c}\text { Previous } \\
\text { Date }\end{array}$ \\
\hline Approval of Mission Need (CD1) & $\operatorname{Jan} 1993$ & Jan 1993 \\
\hline Title I Initiated & $\operatorname{Jan} 1996$ & Jan 1996 \\
\hline NEPA Record of Decision & Dec 1996 & Sep 1996 \\
\hline Approval to Initiate Construction (CD3) & Mar 1997 & Mar 1997 \\
\hline Start Special Equipment Installation & Nov 1998 & Nov 1998 \\
\hline $1^{\text {st }}$ light & Jun 2004 & NA \\
\hline 12 bundle & Jun 2007 & Oct 2003 \\
\hline 24 bundles & Sep 2008 & NA \\
\hline Project Complete (CD4)* & Sep 2008 & Oct 2003 \\
\hline
\end{tabular}

*CD4 was previously defined as 12 bundles commissioned and 12 bundles installed.

$\mathrm{CD} 4$ is now defined as all 24 bundles commissioned.

Project milestones for FY 2000 and FY 2001 include:

- FY 2000

- Complete Optics Facilitization $\quad 1 Q$

1. Complete Optics Assembly Building 3Q

I Place Integration Management and Installation Contract 4Q

I Certification of new cost and schedule baseline $\quad 4 Q$

- FY 2001

I - Supplemental Environmental Impact Statement - Record of Decision $1 Q$

I Inert gas/vacuum Management Pre-Start Review - Phase $3 \quad 2 Q$

I - Award production contracts for amplifier slabs $\quad 3 Q$

1 - End conventional construction $4 Q$ 


\section{Details of Cost Estimate}

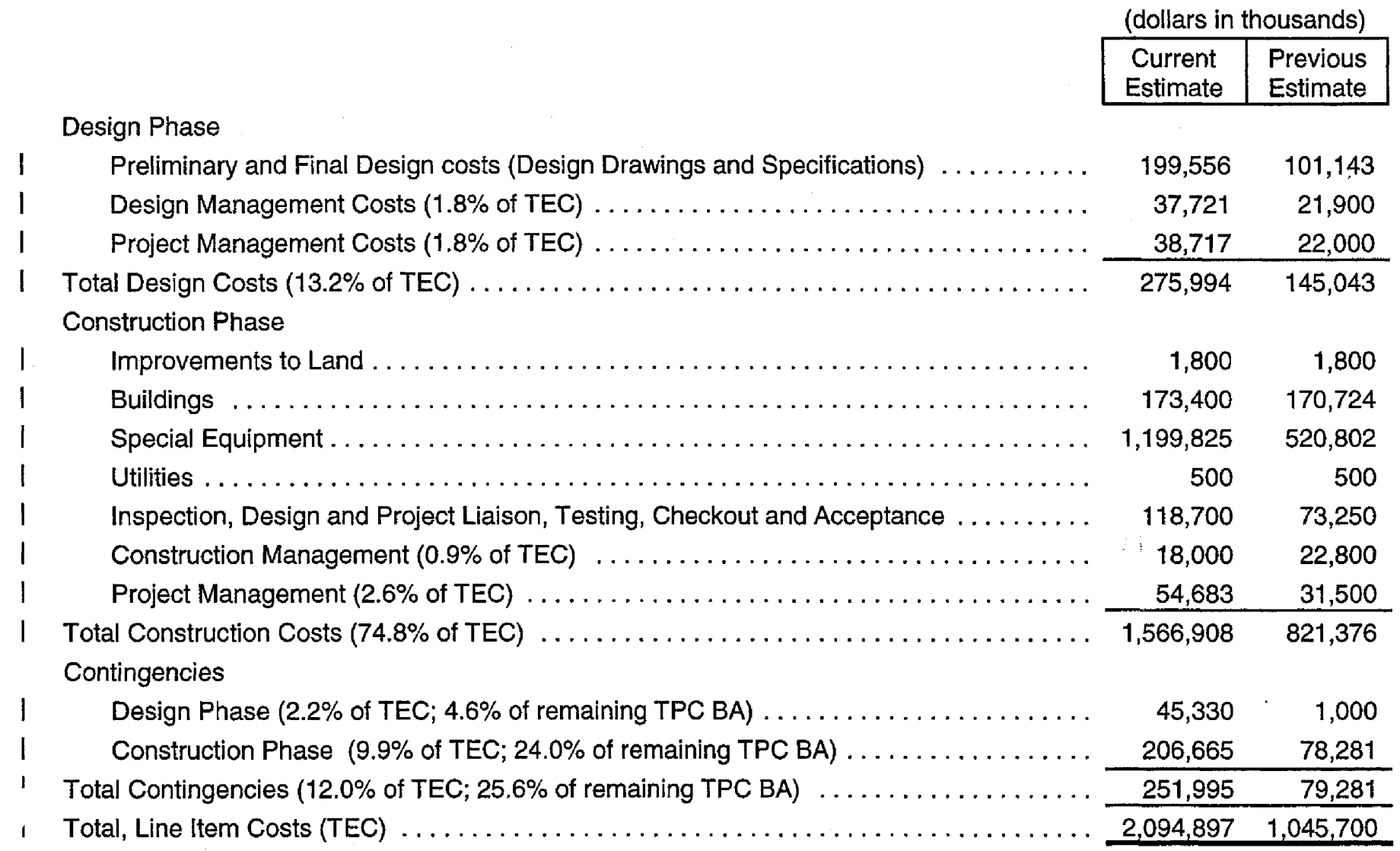

The cost estimate assumes a project organization and cost distribution consistent with the management requirements appropriate for a DOE Major System as outlined in the NIF Project Execution Plan. Actual cost distribution will be in conformance with accounting guidelines in place at the time of project execution. 


\section{Method of Performance}

The NIF Project Office (consisting of LLNL, LANL, SNL, and UR/LLE and supported by competitively selected contracts with Architect/Engineering firms, an integration management and installation contractor, equipment and material vendors, and construction firms) will prepare the design, procure equipment and materials, and perform conventional construction, safety, system analysis, and acceptance tests. DOE/NNSA will maintain oversight and coordination through the Defense Programs Office of the NIF Project. All activities are integrated through the guiding principles and five core functions of the DOE ISMS (DOE P450.4). DOE conducted the site selection and the NEPA determination in the SSMPEIS. LLNL was selected as the construction site in the ROD made on December 19, 1996.

\section{5.1 NIF Execution}

\section{5.1.1 Conceptual and Advanced Conceptual Design}

The conceptual design was completed in May 1994 by the staff of the participating laboratories. Keller and Gannon contractors provided designs of the conventional facilities and equipment.

Design requirements were developed through the Work Smart Standards (WSS) Process approved by the Director of the Oakland Operations Office. New requirements have been defined since the original WSS was placed in Contract 48 in 1997. A gap analysis will be performed, and if changes are required a revision will be prepared.

The Conceptual Design Report was subjected to an Independent Cost Estimate (ICE) review by Foster Wheeler USA under contract to the DOE. The advanced conceptual design phase further developed the design, and is the phase in which all the criteria documents that govern Title I Design were reviewed and updated.

\subsubsection{Title I Design}

In fiscal year 1996, Title I Design began with the contract award for the Architect/Engineers (Parsons and AC Martin) and a Construction Management firm (Sverdrup) for the design and the constructiblity reviews of the (1) NIF Laser and Target Area Building and (2) Optics Assembly Building. Title I Design included developing advanced design details to finalize the building and the equipment arrangements and the service and utility requirements, reviewing project cost estimates and integrated schedule, preparing procurement plans, conducting design reviews, completing the PSAR and NEPA documentation, and planning for and conducting the constructibility reviews.

Title I Design was completed in November 1996 and was followed by an ICE review.

\subsubsection{Title II Design}

The participants in Title II (final design) include LLNL, LANL, SNL, Parsons, AC Martin, and Jacobs/Sverdrup (constructibility reviews). The Title II Design provides construction subcontract 
packages and equipment procurement packages, construction cost estimate and schedule, Acceptance Test Procedures, and the acceptability criteria for tested components (e.g., pumps, power conditioning, special equipment), and environmental permits for construction (e.g., Storm Water Pollution Prevention Plan).

\subsubsection{Title III Design}

The Title III engineering participants include LLNL, Parsons, AC Martin, and Jacobs/Sverdrup. Title III engineering represents the engineering necessary to support the construction and equipment installation, including inspection and field engineering. The main activities are to perform the engineering necessary to resolve issues that may arise during construction (e.g., fit problems, interferences). Title III engineering will result in the final as-built drawings that represent the NIF configuration.

\subsubsection{Construction and Equipment Procurement, Installation, and Acceptance}

Based on the March 7, 1997, Critical Decision 3, construction began with site preparation and excavation of the LTAB forming the initial critical-path activities. The NIF Construction Safety program was approved and sets forth the safety requirements at the construction site for all LLNL and non-LLNL (including contractor) personnel. There was sufficient Title II Design completed to support bid of the major construction and equipment procurements. The conventional facilities are designed as construction subcontract bid packages and competitively bid as firm fixed price procurements. The initial critical-path construction activities include both the Laser and Target Area Building and the Optics Assembly Building (where large optics assembly and staging will take place). In addition, the site support infrastructure needed to support construction of conventional facility, beampath infrastructure installation, and line replaceable equipment and optics staging are being put in place. At the same time, procurements on the critical path (e.g., target chamber) began following the established NIF Acquisition Plan.

The next major critical path activity is the assembly and installation of the Beampath Infrastructure Systems. These are the structural and utility systems required to support the line replaceable units. The management and installation of the Beampath Infrastructure System is being contracted to an Integration Management and Installation Contractor. This was done to fully involve industry in the construction of NIF as directed in the Secretary of Energy's 6-Point Plan and recommended by the Secretary of Energy Advisory Board interim report in January 2000. During the period of Beampath Infrastructure System installation, line replaceable unit and optics procurements continue.

The line replaceable unit equipment will be delivered, staged, and installed as phased beneficial occupancy of the Laser and Target Area Building is achieved. This is a complex period in which priority conflicts may occur because construction, equipment installation, and acceptance testing will be occurring. The Product Line Managers, Area Integration Managers, and Integration Management and Installation Contractor will manage and integrate the activities to avoid potential interferences affecting the schedule. The construction, equipment installation, and acceptance testing will be 
I supported by Title III inspection and field engineering, which will include resolving construction and installation issues and preparing the final as-built drawings.

\subsubsection{Operational Testing and Commissioning}

After installation, the facility and equipment will be commissioned prior to the phased turnover to the operations organization. The transfer points employ the Management Pre-Start Review process in which an independent team evaluates the readiness (e.g., training and qualification of operators, Commissioning Test Procedures results, and as-built drawings) and recommends turnover by the NIF Project Manager. The NIF Project Manager approves the transfer of responsibility for ISMS Work Authorization.

The integrated system activation will begin with the commissioning of the first bundle. Management Pre-Start Reviews (MPRs) will be used by the Project Manager to control each system turnover. In specific cases, such as first light, first experiment, and ignition readiness, the DOE/NNSA Field Office will oversee and concur in the MPR. A sequence of MPRs are scheduled to ensure a disciplined and controlled turnover of NIF systems from construction to activation. MPRs will be conducted by LLNL prior to the start of first experiments and NIF 192-beam operation, and the results will be validated by the Defense Programs Office of the NIF Readiness Assessment. The first experiment and 192-beam Readiness Assessment requires that the FSAR be completed and approved (including the documented operating/maintenance procedures, operating staff training, and as-built design documentation). The 192-beam Readiness Assessment results are a key input for Critical Decision 4 (Project closeout) by the Acquisition Executive.

\subsubsection{Project Completion}

The complete set of NIF criteria is contained in the NIF Functional Requirements and Primary Criteria. These are the criteria that NIF is required to meet when fully operational. However, early test operation of NIF by the Program through a series of turnovers controlled by Management PreStart Reviews will be achieved by a phased transition to Program operations for user tests before Project completion. This enables the Program to begin experimental operations in support of Stockpile Stewardship and other programmatic missions at the earliest possible date, as NIF performance capability is building up toward the eventual goals set out in the NIF Functional Requirements and Primary Criteria and Project Completion Criteria. 


\section{Schedule of Project Funding}

\begin{tabular}{|c|c|c|c|c|c|c|}
\hline & \multicolumn{6}{|c|}{ (dollars in thousands) } \\
\hline & Prior Years & \begin{tabular}{|l|l|}
$F Y 1999$ \\
\end{tabular} & FY 2000 & FY 2001 & Outyears & Total \\
\hline \multicolumn{7}{|l|}{ Project Cost } \\
\hline \multicolumn{7}{|l|}{ Facility Costs } \\
\hline Design .. & 143,043 & 75,000 & 50,000 & 30,000 & 23,281 & 321,324 \\
\hline Construction & 130,630 & 176,476 & 190,600 & 278,370 & 997,497 & $1,773,573$ \\
\hline Total, Line item TEC & 273,673 & 251,476 & 240,600 & 308,370 & $1,020,778$ & $2,094,897$ \\
\hline \multicolumn{7}{|l|}{ Other Project Costs } \\
\hline R\&D necessary to complete construction ${ }^{a}$ & 85,126 & 13,909 & 2,252 & 3,238 & 0 & 104,525 \\
\hline Conceptual design costs ${ }^{b} \ldots \ldots \ldots \ldots$ & 12,300 & 0 & 0 & 0 & 0 & 12,300 \\
\hline NEPA documentation costs ${ }^{c} \ldots \ldots \ldots$ & 3,754 & 601 & 370 & 600 & 1,275 & 6,600 \\
\hline Other project-related costs & 18,815 & 1,638 & 660 & 480 & 8,182 & 29,775 \\
\hline Total, Other Project Costs . . . . . & 119,995 & 16,148 & 3,282 & 4,318 & 9,457 & 153,200 \\
\hline Total Project Cost (TPC) . & 393,668 & 267,624 & 243,882 & 312,688 & $1,030,235$ & $2,248,097$ \\
\hline $\begin{array}{l}\text { Other Related Operations and Maintenance Costs - } \\
\text { NIF Demonstration Program } \ldots \ldots \ldots \ldots \ldots\end{array}$ & 276,400 & 55,648 & 70,723 & 76,799 & 720,430 & $1,200,000$ \\
\hline TOTAL Project and Related Costs . . . . . . . . . . & 670,068 & 323,272 & 314,605 & 389,487 & $1,750,665$ & $3,448,097$ \\
\hline \multicolumn{7}{|l|}{ Budget Authority $(B A)$ requirements $f$} \\
\hline TEC (capital funding) $\ldots \ldots \ldots$ & 367,100 & 284,200 & 247,158 & 209,100 & 987,339 & $2,094,897$ \\
\hline OPC (O\&M funding) $\ldots \ldots \ldots \ldots \ldots \ldots$ & 132,300 & 6,800 & 5,900 & 5,900 & 2,300 & 153,200 \\
\hline NIF Demonstration Program (O\&M funding) & 276,400 & 65,900 & 77,200 & 60,800 & 719,700 & $1,200,000$ \\
\hline Total, BA requirements $\ldots \ldots \ldots \ldots \ldots$ & 775,800 & 356,900 & 330,258 & 275,800 & $1,709,339$ & $3,448,097$ \\
\hline
\end{tabular}

${ }^{\mathrm{a}}$ Costs include optics vendor facilitization and optics quality assurance.

${ }^{b}$ Includes original conceptual design report completed in FY 1994 and the conceptual design activities for the optical assembly and refurbishment capability and site infrastructure.

${ }^{c}$ Includes preparation of the NIF portion of the Stockpile Stewardship and Management Programmatic Environmental Impact Statement, NIF Supplemental Environmental Impact Statement and environmental monitoring and permits.

d Includes engineering studies (including advanced conceptual design) of project options; assurances, safety analysis, and integration; start-up planning, management, training and staffing; procedure preparation; startup; and Operational Readiness Review.

${ }^{e}$ Funding previously requested and appropriated in the Inertial Confinement Fusion Program and, beginning in FY 2001, under Readiness in Technical Base and Facilities, NIF Operations.

${ }^{f}$ Long-lead procurements and contracts require BA in advance of costs. 


\section{Related Annual Funding Requirements}

(dollars in thousands)

\begin{tabular}{|c|c|}
$\begin{array}{c}\text { Current } \\
\text { Estimate }\end{array}$ & $\begin{array}{c}\text { Previous } \\
\text { Estimate }\end{array}$ \\
\hline 38,767 & 21,200 \\
55,787 & 33,200 \\
41,865 & 61,100 \\
& \\
204 & 200 \\
204 & 200 \\
6,637 & 9,000 \\
1,577 & 6,300 \\
\hline \multicolumn{2}{|c}{} \\
$145,042^{f}$ & $131,200^{g}$ \\
\hline
\end{tabular}

${ }^{a}$ Includes all NIF support personnel not in maintenance/repair, some of which were included previously in Programmatic expenses (245 personnel).

${ }^{b}$ Includes refurbishment of laser \& target systems, building maintenance, and component procurement (137 personnel).

${ }^{c}$ Includes the LLNL portion of the national ICF Program that is directly related to the use of NIF but not facility scientific support, which is now included in facility operating costs.

${ }^{d}$ Estimate of electricity usage.

${ }^{e}$ Estimate of industrial gases (argon, synthetic air).

f In FY2001 dollars.

${ }^{g}$ In FY 2000 dollars. 


\section{Design and Construction of Federal Facilities}

All DOE facilities are designed and constructed in accordance with applicable Public Laws, Executive Orders, OMB Circulars, Federal Property Management Regulations, and DOE Orders. The total estimated cost of the project includes the cost of measures necessary to assure compliance with Executive Order 12088, "Federal Compliance with Pollution Control Standards"; Section 19 of the Occupational Safety and Health Act of 1970, the provisions of Executive Order 12196, and the related Safety and Health provisions for Federal Employees (CFR Title 29, Chapter XVII, Part 1960); and the Architectural Barriers Act, Public Law 90-480, and implementing instructions in 41 CFR 101-19.6.

The project will be located in an area not subject to flooding determined in accordance with Executive Order 11988.

DOE has reviewed the GSA inventory of Federal Scientific laboratories and found insufficient space available, as reported by the GSA inventory. 


\section{Appendix E}

\section{NIF Project Baseline Costs}


Table E-1. NIF Annual Financial Schedule (Escalated \$M)

\begin{tabular}{|c|c|c|c|c|c|c|c|c|c|c|c|c|c|c|c|c|c|}
\hline & $F Y 93$ & FY94 & FY95 & FY96 & FY97 & FY98 & FY99 & FYo0 & FYo1 & FY02 & FY03 & FY04 & FY0S & FY06 & FYOY & FY08 & Total \\
\hline \multicolumn{18}{|c|}{$\begin{array}{c}\text { Total Estimated } \\
\text { Cost }\end{array}$} \\
\hline BA & & & & 37.4 & 131.9 & 197.8 & 284.2 & 247.2 & 209.1 & 245.0 & 187.2 & 150.0 & 130.0 & 130.0 & 130.0 & 15.1 & 2094.9 \\
\hline BO & & & & 34.0 & 74.3 & 165.4 & 251.5 & 240.6 & 308.4 & 254.9 & 196.6 & 136.2 & 128.6 & 130.2 & 145.4 & 28.8 & 2094.9 \\
\hline \multicolumn{18}{|c|}{$\begin{array}{c}\text { Other Project } \\
\text { Cost }\end{array}$} \\
\hline $\mathrm{BA}$ & 6.0 & 6.2 & 6.0 & 23.6 & 59.2 & 31.3 & 6.8 & 5.9 & 5.9 & 1.4 & 0.9 & & & & & & 153.2 \\
\hline BO & 2.6 & 9.6 & 5.3 & 19.1 & 29.8 & 53.6 & 16.1 & 3.3 & 4.3 & 1.2 & 2.7 & 1.2 & 1.0 & 0.9 & 1.2 & 1.2 & 153.2 \\
\hline \multicolumn{18}{|c|}{$\begin{array}{c}\text { Total Project } \\
\text { Cost }\end{array}$} \\
\hline$B A$ & 6.0 & 6.2 & 6.0 & 61.0 & 191.1 & 229.1 & 291.0 & 253.1 & 215.0 & 246.4 & 188.1 & 150.0 & 130.0 & 130.0 & 130.0 & 15.1 & 2248.1 \\
\hline$B O$ & 2.6 & 9.6 & 5.3 & 53.1 & 104.1 & 219.0 & 267.6 & 243.9 & 312.7 & 256.1 & 199.3 & 137.5 & 129.6 & 131.1 & 146.6 & 30.0 & 2248.1 \\
\hline
\end{tabular}

Table E-2. NIF Annual Cost Plan at NWBS Level 2 and selected Level 3 (Escalated \$M)

\begin{tabular}{|c|c|c|c|c|c|c|c|c|c|c|c|c|}
\hline Cost Profile & NWBS & FY93-99 & FYOO & FY0T| & FY02 & FY03 & FY04 & FY05 & FY06 & FYOT & FYo8 & Total \\
\hline \multicolumn{13}{|l|}{ Total Estimated Cost } \\
\hline $\begin{array}{l}\text { Assembly, Installation, Refurbishment } \\
\text { Equipment. }\end{array}$ & N.A & 16.6 & 12.4 & 10.9 & 3.7 & 3.1 & 0.1 & 0.0 & 0.0 & & $0 . \bar{q}$ & \\
\hline Integrated Computers and Controls & N.C & 27.6 & 5.4 & 4.6 & 5.4 & 7.3 & 4.1 & 2.5 & 1.1 & 0.0 & $0 . \overline{0}$ & 58.2 \\
\hline Conventional Facilities & N.F & 180.2 & 26.8 & 27.1 & 0.8 & $0 . \hat{3}$ & 0.0 & 0.8 & 0.0 & 0.0 & $0 . \overline{0}$ & 235.9 \\
\hline Main Laser System & N.L.1 & 122.4 & 92.8 & 105.4 & 71.2 & 46.9 & 56.6 & 75.3 & 86.9 & 103.1 & 74.7 & 775.3 \\
\hline Multiplexed Diagnostics & N.L. 2 & 6.2 & 4.2 & 5.0 & 4.0 & 3.7 & 1.4 & $0 . \overline{6}$ & 0.6 & 0.4 & 0.0 & 26.1 \\
\hline Laser Transport \& 3w Systems & N.L.3 & 30.5 & 25.7 & 32.7 & 24.6 & 20.7 & 11.3 & 12.0 & 11.4 & 14.6 & 2.8 & 186.5 \\
\hline $\begin{array}{l}\text { Laser System Beam Control and } \\
\text { Diagnostics }\end{array}$ & N.L. 4 & 0.0 & 5.8 & 3.6 & 4.4 & 4.0 & 2.3 & 7.7 & 0.7 & 0.1 & 0.0 & 22.7 \\
\hline Laser System Integration & N.L.S & 1.1 & 1.8 & 2.9 & 1.2 & 0.7 & 0.0 & 0.0 & 0.0 & 0.0 & 0.0 & 6.7 \\
\hline Laser System Optical Integration & N.L.6 & 19.8 & 7.1 & 13.4 & 10.3 & 10.2 & 4.7 & 0.0 & 0.0 & 0.0 & 0.0 & 65.5 \\
\hline Management & N.M & 75.6 & 38.4 & 31.4 & 25.7 & 23.2 & 8.4 & 3.7 & 1.9 & 1.2 & 0.6 & 210.0 \\
\hline Target Experimental Systems & N.T & 38.8 & 3.9 & 3.8 & 2.2 & 3.1 & 7.3 & 0.1 & 0.1 & 0.1 & 0.0 & 53.6 \\
\hline Utilities & N.U & 6.3 & 16.4 & 26.4 & 61.1 & 35.5 & 9.4 & 0.3 & 0.2 & 0.0 & 0.0 & 155.6 \\
\hline Contingency & & 0.0 & & 42.2 & 40.3 & 37.8 & 36.5 & 31.6 & 27.2 & 25.8 & 10.5 & 252.0 \\
\hline Total PACE Funded & & 525.2 & 240.6 & 308.4 & 254.9 & 196.6 & 136.2 & 128.6 & 130.2 & 145.4 & 28.8 & 2094.9 \\
\hline & & & & & & & & & & & & \\
\hline \multicolumn{13}{|l|}{ Other Project Cost } \\
\hline Main Laser System & N.L.1 & & 0.2 & 0.0 & 0.0 & 0,0 & 0.0 & 0.0 & 0.0 & 0.0 & 0.0 & 0.2 \\
\hline Laser System Optical Integration & N.L.6 & 99.1 & 2.1 & 3.2 & 0.0 & 0.0 & 0.0 & 0.0 & 0.0 & 0.0 & 0.0 & 104.4 \\
\hline Management & N.M & 37.0 & 1.0 & 1.1 & 1.2 & 2.7 & 1.2 & 1.0 & 0.9 & 1.2 & 1.2 & 48.6 \\
\hline Total O\&M Funded & & 136.1 & 3.3 & 4.3 & 1.2 & 2.7 & $T .2$ & $\pi .0$ & 0.9 & 1.2 & 1.2 & 153.2 \\
\hline Total Project Cos & & 661.3 & 243.9 & अ2.7 & 256.1 & 199.3 & 137.5 & 129.6 & 131.1 & 746.6 & 30.0 & 2248.1 \\
\hline
\end{tabular}




\section{Appendix F}

NIF Project Integrated Schedule, Major Milestones and Critical Decisions, and NIF Project Documents 


\section{NIF Project Integrated Schedule, Major Milestones and Critical Decisions, and NIF Project Documents}

This appendix contains the NIF Summary Integrated Project Schedule (Figure F-1), Major Project Milestones and Critical Decision Points (Table F-1), and NIF Project Documents (Table F-2).

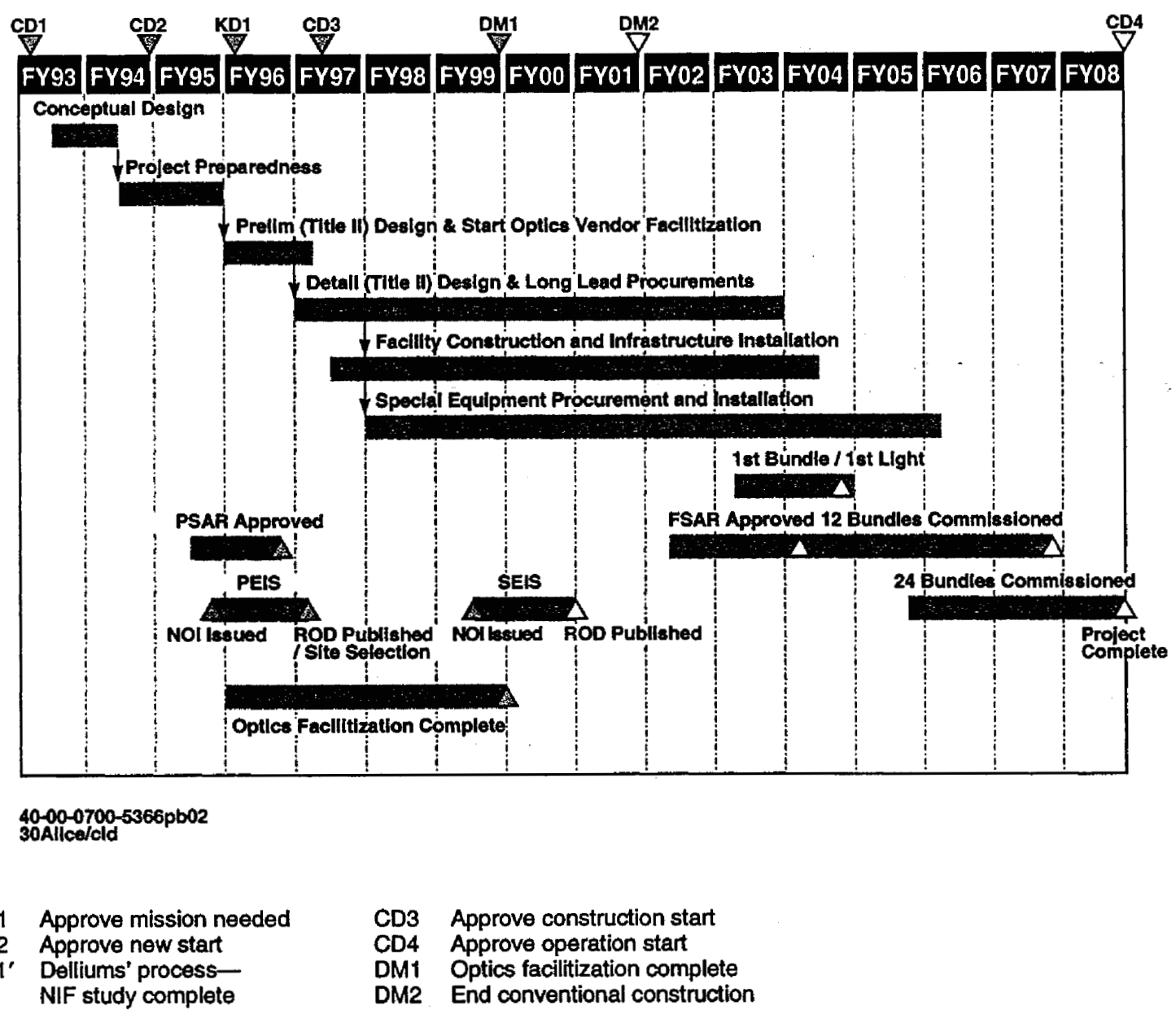

Figure F-1. NIF Summary Integrated Project Schedule. 
Table F-1. NIF Project Major Milestones and Critical Decision Points.

\begin{tabular}{|c|c|c|c|c|c|c|c|}
\hline $\begin{array}{c}\text { Activity } \\
\text { ID }\end{array}$ & Milestone Description & \begin{tabular}{|c|} 
DOE Acquisition \\
Executive \\
Level 0 \\
\end{tabular} & $\begin{array}{c}\text { NNSA Deputy } \\
\text { Administrator for } \\
\text { Defense Projects } \\
\text { Level 1 } \\
\end{array}$ & $\begin{array}{c}\text { NNSA Office } \\
\text { of the NIF } \\
\text { Project } \\
\text { Level } 2 \\
\end{array}$ & $\begin{array}{c}\text { NIF Project } \\
\text { Manager } \\
\text { Level } 3 \\
\end{array}$ & $\begin{array}{c}\text { Planned } \\
\text { Dates }\end{array}$ & $\begin{array}{c}\text { Actual } \\
\text { Dates } \\
\end{array}$ \\
\hline 10 & CD1-Approval of Mission Need & $\mathrm{X}$ & & & & Jan-93 & Jan-93 \\
\hline 3010 & CDR Complete & & & & $X$ & May-94 & May-94 \\
\hline 20 & CD2-Approval of New Start & $\mathrm{X}$ & & & & Oct-94 & Oct-94 \\
\hline 1010 & Notice of Intent Issued & & $\mathrm{X}$ & & & Jun-95 & Jun-95 \\
\hline 3020 & Architect/Engineer Contracted & & & & $X$ & Dec-95 & Dec-95 \\
\hline 30 & KD1'Dellums Process Complete & $\mathrm{X}$ & & & & Dec-95 & Dec-95 \\
\hline 3030 & Title I Initiated & & & & $\mathrm{X}$ & Jan-96 & Jan-96 \\
\hline 3040 & Construction Manager Contracted & & & & $\mathrm{x}$ & May-96 & May-96 \\
\hline 2010 & PSAR DOE Concurrence & & & $\mathrm{x}$ & & Aug-96 & Aug-96 \\
\hline 3050 & PSAR Approved & & & & $\mathrm{X}$ & Sep-96 & Sep-96 \\
\hline 1020 & Approval to Initiate Title II Design & & $\mathrm{x}$ & & & Nov-96 & Nov-96 \\
\hline 1030 & $\begin{array}{l}\text { Approval to Initiate Long Lead } \\
\text { Procurement }\end{array}$ & & $\mathrm{x}$ & & & Nov-96 & Nov-96 \\
\hline 40 & NEPA Record of Decision & $X$ & & & & Dec-96 & Dec-96 \\
\hline 50 & $\begin{array}{l}\text { CD3-Approval to Initiate Title II } \\
\text { Construction }\end{array}$ & $\mathrm{X}$ & & & & Mar-97 & Mar-97 \\
\hline 2020 & $\begin{array}{l}\text { Issue Pollution Prevention/Waste Min } \\
\text { Plan }\end{array}$ & & & $\mathrm{X}$ & & Aug-98 & Aug -98 \\
\hline 3060 & Start Special Equipment Installation & & & & $\mathrm{X}$ & Nov-98 & Nov- 98 \\
\hline 1040 & Optics Facilitization Complete (DM-1) & & $\mathrm{X}$ & & & Dec-99 & Dec-99 \\
\hline
\end{tabular}




\begin{tabular}{|c|c|c|c|c|c|c|c|}
\hline $\begin{array}{c}\text { Activity } \\
\text { ID }\end{array}$ & Milestone Description & \begin{tabular}{|c} 
DOE Acquisition \\
Executive \\
Level 0
\end{tabular} & $\begin{array}{c}\text { NNSA Deputy } \\
\text { Administrator for } \\
\text { Defense Projects } \\
\text { Level } 1 \\
\end{array}$ & $\begin{array}{l}\text { NNSA Office } \\
\text { of the NIF } \\
\text { Project } \\
\text { Level } 2 \\
\end{array}$ & 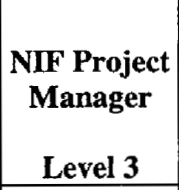 & $\begin{array}{c}\text { Planned } \\
\text { Dates }\end{array}$ & $\begin{array}{c}\text { Actual } \\
\text { Dates }\end{array}$ \\
\hline 60 & Rebaseline Plan Approved & $\mathrm{X}$ & & & & May-00 & May-00 \\
\hline 2040 & IMI Contract Approved & & & $\mathrm{X}$ & & Sep-00 & \\
\hline 3210 & $\begin{array}{l}\text { OAB MPR Phase 1-Permit Equipment } \\
\text { Installation }\end{array}$ & & & & $\mathrm{X}$ & Sep-00 & \\
\hline 2030 & SEIS Record of Decision & & & $\mathrm{X}$ & & Oct-00 & \\
\hline 3240 & $\begin{array}{l}\text { Inert Gas/Vacuum MPR Phase 3-Permit } \\
\text { SF Vacuum }\end{array}$ & & & & $\mathrm{X}$ & Mar-01 & \\
\hline 1050 & End Conventional Construction (DM-2) & & $\mathrm{X}$ & & & Sep-01 & \\
\hline 2050 & Target Chamber Positioned & & & $\mathrm{X}$ & & Mar-02 & \\
\hline 2060 & $\begin{array}{l}\text { Joint MPR-OAB Phase 2-Permit LRU } \\
\text { Assembly }\end{array}$ & & & $\mathrm{x}$ & & Apr-03 & \\
\hline 3320 & $\begin{array}{l}\text { LRU Installation MPR P2-Permit LB2 } \\
\text { LRU Instl }\end{array}$ & & & & $\mathrm{x}$ & Aug-03 & \\
\hline 3205 & $\begin{array}{l}\text { OPDL MPR-Permit Production Optics } \\
\text { Processing }\end{array}$ & & & & $\mathrm{X}$ & Oct-03 & \\
\hline 3310 & $\begin{array}{l}\text { LRU Installation MPR P1-Permit } \\
\text { PAM/PABTS Instl }\end{array}$ & & & & $\mathrm{X}$ & Oct-03 & \\
\hline 3280 & $\begin{array}{l}\text { PCS MPR-Permit LB2 Flashlamp Test } \\
\text { Main Amp P1 }\end{array}$ & & & & $\mathrm{X}$ & Oct-03 & \\
\hline 3330 & $\begin{array}{l}\text { LRU Installation MPR P3-Permit SY2 } \\
\text { LRU Instl }\end{array}$ & & & & $\mathrm{X}$ & Oct-03 & \\
\hline 3110 & $\begin{array}{l}\text { IIS MPR Phase 1-Permit PAMMA } \\
\text { Operations }\end{array}$ & & & & $\mathrm{X}$ & Nov-03 & \\
\hline 3070 & FSAR Approved & & & & $\mathrm{x}$ & Dec-03 & \\
\hline 3340 & $\begin{array}{l}\text { LRU Installation MPR P4-Permit TB } \\
\text { LRU Instl }\end{array}$ & & & & $\mathrm{X}$ & Dec-03 & \\
\hline 3410 & $\begin{array}{l}\text { Light Propagation MPR P1-Permit } \\
\text { Light in LB2-TB }\end{array}$ & & & & $\mathrm{X}$ & Dec-03 & \\
\hline
\end{tabular}




\begin{tabular}{|c|c|c|c|c|c|c|c|}
\hline $\begin{array}{c}\text { Activity } \\
\text { ID }\end{array}$ & Milestone Description & \begin{tabular}{|c|}
$\begin{array}{c}\text { DOE Acquisition } \\
\text { Executive } \\
\\
\text { Level 0 }\end{array}$ \\
\end{tabular} & \begin{tabular}{|c} 
NNSA Deputy \\
Administrator for \\
Defense Projects \\
Level 1 \\
\end{tabular} & $\begin{array}{c}\text { NNSA Office } \\
\text { of the NIF } \\
\text { Project } \\
\text { Level } 2 \\
\end{array}$ & \begin{tabular}{|c|}
$\begin{array}{c}\text { NIF Project } \\
\text { Manager }\end{array}$ \\
Level 3 \\
\end{tabular} & $\begin{array}{c}\text { Planned } \\
\text { Dates }\end{array}$ & $\begin{array}{c}\text { Actual } \\
\text { Dates }\end{array}$ \\
\hline 2070 & FSAR NNSA Concurrence & & & $\mathrm{X}$ & & Jan-04 & \\
\hline 3120 & $\begin{array}{l}\text { ILS MPR Phase 2-Permit MOR } \\
\text { Operations }\end{array}$ & & & & $\mathrm{x}$ & Jan-04 & \\
\hline 3130 & $\begin{array}{l}\text { ПS MPR Phase 3-Permit PASS Laser } \\
\text { Align }\end{array}$ & & & & $\mathrm{X}$ & Jan-04 & \\
\hline 3140 & $\begin{array}{l}\text { ILS MPR Phase 4-Permit ILS } \\
\text { Integration Testing }\end{array}$ & & & & $\mathrm{X}$ & Jan-04 & \\
\hline 3420 & $\begin{array}{l}\text { Light Propagation MPR P2-Permit } \\
\text { Light in LB2 }\end{array}$ & & & & $\mathrm{X}$ & Feb-04 & \\
\hline 3430 & $\begin{array}{l}\text { Light Propagation MPR P3-Permit } \\
\text { Light in PDS }\end{array}$ & & & & $\mathrm{X}$ & Feb-04 & \\
\hline 2080 & $\begin{array}{l}\text { Joint MPR-Light Propagation Phase 4- } \\
\text { Permit Light to Target Bay }\end{array}$ & & & $\mathrm{X}$ & & Feb-04 & \\
\hline 3220 & $\begin{array}{l}\text { Inert Gas/Vacuum MPR Phase 1-Permit } \\
\text { TC Vacuum }\end{array}$ & & & & $\mathrm{X}$ & Mar-04 & \\
\hline 3230 & $\begin{array}{l}\text { Inert Gas/Vacuum MPR Phase 2-Permit } \\
\text { Gas Filling }\end{array}$ & & & & $\mathrm{X}$ & May-04 & \\
\hline 3520 & First Light to Target Chamber Center & & & & $\mathrm{X}$ & Jun-04 & \\
\hline 3500 & $\begin{array}{l}\text { First Experiments Readiness } \\
\text { Assessment }\end{array}$ & & & & $\mathrm{x}$ & Nov-04 & \\
\hline 3510 & $\begin{array}{l}\text { 10kj } 1 \mathrm{w} \text { to Precision Diagnostics- } \\
\text { LB2/SY2 }\end{array}$ & & & & $\mathrm{X}$ & Dec-04 & \\
\hline 3590 & 1st Bundle Commissioned & & & & $\mathrm{X}$ & Dec-04 & \\
\hline 2090 & $\begin{array}{l}\text { NNSA Approval First Experiments } \\
\text { Readiness Assessment }\end{array}$ & & & $\mathrm{x}$ & & Jan-05 & \\
\hline 3350 & $\begin{array}{l}\text { LRU Installation MPR P5-Permit LB1 } \\
\text { LRU Instl }\end{array}$ & & & & $\mathrm{X}$ & Jan-06 & \\
\hline 3290 & $\begin{array}{l}\text { PCS MPR-Permit LB1 Flashlamp Test } \\
\text { Main Amp P2 }\end{array}$ & & & & $\mathrm{X}$ & Feb-06 & \\
\hline 1060 & $\begin{array}{l}\text { Beampath Infrastructure } \\
\text { Commissioning Complete }\end{array}$ & & $\mathrm{X}$ & & & Mar-06 & \\
\hline
\end{tabular}




\begin{tabular}{|c|c|c|c|c|c|c|c|}
\hline $\begin{array}{l}\text { Activity } \\
\text { ID }\end{array}$ & Milestone Description & \begin{tabular}{|} 
DOE Acquisition \\
Executive \\
Level 0 \\
\end{tabular} & $\begin{array}{c}\text { NNSA Deputy } \\
\text { Administrator for } \\
\text { Defense Projects } \\
\text { Level } 1 \\
\end{array}$ & $\begin{array}{c}\text { NNSA Office } \\
\text { of the NIF } \\
\text { Project } \\
\text { Level } 2 \\
\end{array}$ & \begin{tabular}{|c}
$\begin{array}{c}\text { NIF Project } \\
\text { Manager }\end{array}$ \\
Level 3 \\
\end{tabular} & $\begin{array}{l}\text { Planned } \\
\text { Dates }\end{array}$ & $\begin{array}{c}\text { Actual } \\
\text { Dates }\end{array}$ \\
\hline 3600 & 6 Bundles Commissioned & & & & $\mathrm{X}$ & Jun-06 & \\
\hline 3360 & $\begin{array}{l}\text { LRU Installation MPR P6-Permit SY1 } \\
\text { LRU Instl }\end{array}$ & & & & $\mathrm{X}$ & Aug-06 & \\
\hline 3450 & $\begin{array}{l}\text { Light Propagation MPR P5-Permit } \\
\text { Light in LB1 }\end{array}$ & & & & $\mathrm{X}$ & Sep-06 & \\
\hline 3460 & $\begin{array}{l}\text { Light Propagation MPR P6-Permit } \\
\text { Light in SY1 }\end{array}$ & & & & $\mathrm{X}$ & Nov-06 & \\
\hline 3610 & 9 Bundles Commissioned & & & & $\mathrm{x}$ & Dec-06 & \\
\hline 2110 & 4-Fold Symmetry Capability & & & $\mathrm{X}$ & & Dec-06 & \\
\hline 3620 & 12 Bundles Commissioned & & & & $\mathrm{X}$ & Jun-07 & \\
\hline 2120 & $\begin{array}{l}\text { 8-Fold Symmetry in One Cone } \\
\text { Capability }\end{array}$ & & & $\mathrm{X}$ & & Jun-07 & \\
\hline 3630 & 15 Bundles Commissioned & & & & $\mathrm{X}$ & Dec-07 & \\
\hline 2130 & $\begin{array}{l}\text { 8-Fold Symmetry in Two Cones } \\
\text { Capability }\end{array}$ & & & $\mathrm{X}$ & & Dec-07 & \\
\hline 3640 & 18 Bundles Commissioned & & & & $\mathrm{X}$ & Mar-08 & \\
\hline 3680 & Security Review (LLNL) & & & & $\mathrm{X}$ & May-08 & \\
\hline 2150 & Security Review (NNSA) & & & $\mathrm{x}$ & & May-08 & \\
\hline 3670 & $\begin{array}{l}\text { Readiness Assessment-Full NIF } \\
\text { Operations (LLNL) }\end{array}$ & & & & $X$ & May-08 & \\
\hline 2140 & $\begin{array}{l}\text { Readiness Assessment-Full NIF } \\
\text { Operation (Office of the NIF) }\end{array}$ & & & $\mathrm{x}$ & & Jul-08 & \\
\hline 3660 & 24 Bundles Commissioned & & & & $X$ & Sep-08 & \\
\hline 70 & CD4-Approval to Begin Operations & $\mathrm{x}$ & & $\mathrm{x}$ & & Sep-08* & \\
\hline
\end{tabular}

$*=\mathrm{CD} 4$ is now defined as all 24 Bundles Commissioned 
- Table F-2. NIF Project Documents.

\begin{tabular}{|c|c|c|c|c|c|c|c|c|}
\hline \multirow[b]{2}{*}{ Document } & \multirow[b]{2}{*}{ Freq. } & \multicolumn{7}{|c|}{ Responsibilities } \\
\hline & & $\mathrm{AE}^{*}$ & NNSA $^{* *}$ & $\mathrm{EH}^{* * *}$ & $\mathrm{OECM}^{* * * *}$ & ONIF***** & NPOt & NEPAt† \\
\hline Justification of Mission Need & o & $\mathrm{A}$ & $\mathbf{P}$ & - & - & - & - & - \\
\hline Project Data Sheet & $\mathbf{a}$ & - & A & - & $\mathrm{R}$ & $\mathbf{R}$ & $\mathrm{P}$ & - \\
\hline Project Charter & o & - & $\mathrm{P}, \mathrm{A}$ & - & - & $\mathrm{I}$ & $\mathrm{I}$ & - \\
\hline Project Execution Plan & $\mathbf{n}$ & - & $\mathrm{A}$ & - & - & $P, C$ & $\mathrm{P}, \mathrm{C}$ & - \\
\hline Primary Criteria & $\mathbf{n}$ & - & A & - & - & I & $\mathrm{P}$ & - \\
\hline Functional Requirements & $\mathrm{n}$ & - & $\mathrm{I}$ & - & - & A & $\mathrm{P}$ & - \\
\hline System Design Requirements & $\mathbf{n}$ & - & - & - & - & I & $\mathrm{P}, \mathrm{A}$ & - \\
\hline Interface Control Documents & $\mathbf{n}$ & - & - & - & - & I & $\mathrm{P}, \mathrm{A}$ & - \\
\hline Preliminary Hazards Analysis & o & - & $\mathrm{C}$ & - & - & C & $\mathrm{P}, \mathrm{A}$ & - \\
\hline Quality Assurance Plan & $\mathbf{n}$ & - & I & - & - & C & $P, A$ & - \\
\hline Conceptual Design Report & $\circ$ & - & $\mathrm{R}$ & - & - & $\mathrm{R}$ & $\mathrm{P}, \mathrm{A}$ & - \\
\hline Environmental Permits ${ }^{\dagger \dagger}$ & $\mathrm{n}$ & - & - & - & - & $\mathrm{C}$ & $P$ & - \\
\hline NEPA (SSMPEIS/ROD) & o & A & $\mathrm{R}$ & $\mathrm{C}$ & - & In & In & $P$ \\
\hline Prelim. Safety Analysis Report & o & - & $\mathrm{C}$ & - & - & C & $\mathrm{P}, \mathrm{A}$ & - \\
\hline ES\&H Plan & $\mathrm{n}$ & - & 1 & - & - & C & $\mathrm{P}, \mathrm{A}$ & - \\
\hline Security Plan & $\mathrm{n}$ & - & I & - & - & $\mathrm{C}$ & $\mathrm{P}, \mathrm{A}$ & - \\
\hline Quality Assurance Audit & $\mathrm{n}$ & - & I & - & - & $\mathrm{P}$ & $\mathrm{I}$ & - \\
\hline Construction Completion Report & o & - & I & - & - & $\mathrm{A}$ & $\mathrm{P}$ & - \\
\hline Project Control Manual & $\mathrm{n}$ & - & I & - & - & I & $\mathrm{P}, \mathrm{A}$ & - \\
\hline Final Safety Analysis Report & $\mathrm{o}$ & - & $\mathrm{C}$ & - & - & $\mathrm{C}$ & $\mathrm{P}, \mathrm{A}$ & - \\
\hline Operational Test Procedures & $\mathrm{n}$ & - & - & - & - & - & P, Att†t & \\
\hline LLNL Readiness Assessment Report & o & - & - & - & - & - & $\mathrm{P}, \mathrm{A}$ & - \\
\hline NNSA Readiness Assessment Report & o & - & - & - & - & $\mathrm{P}, \mathrm{A}$ & I & - \\
\hline Annual Budget Validation Report & $\mathrm{a}$ & - & $\mathrm{R}$ & - & $\mathrm{P}, \mathrm{A}$ & $\mathrm{R}$ & $\mathrm{R}$ & - \\
\hline Unusual Occurrence Report & $\mathrm{n}$ & - & $\mathrm{I}$ & $\mathrm{I}$ & - & I & $\mathrm{P}, \mathrm{A}$ & - \\
\hline Configuration Management Plan & $\mathbf{n}$ & - & $\mathrm{I}$ & - & - & $\mathrm{C}$ & $\mathrm{P}, \mathrm{A}$ & - \\
\hline Monthly Status Report & $\mathrm{m}$ & - & I & - & - & $\mathrm{I}$ & $\mathrm{P}$ & - \\
\hline Quarterly Status Report & $\mathrm{q}$ & - & I & - & $\mathrm{I}$ & $\mathrm{P}$ & $\mathrm{P}$ & - \\
\hline Project Acquisition Plan & o & - & - & - & - & I & A & - \\
\hline Joint MPRs ${ }^{+}+\dagger \dagger t$ & $\circ$ & - & I & - & - & $\mathrm{C}$ & $\mathrm{A}$ & - \\
\hline Readiness Assessments †t††† & o & - & - & - & - & $\mathrm{C}$ & $A$ & - \\
\hline
\end{tabular}

* Acquisition Executive

* National Nuclear Security Administration

** Environmental Safety and Health

*** Office of Engineering and Construction Management

$\cdots$ Office of the NIF Project

NIF Project Office

If National Environmental Policy Act preparer

Ht Approval by Environmental Protection Agency, Regional Air Quality Districts

HIf Results will be included in the Readiness Assessment

HIH Light Propagaton Phase 4, Tritium Systems and Cry ogenic Target, High-Yield Ignition Readiness, OAB Phase II- Permit LRU Assembly

$\mathrm{HtH}$ First experiments, full 192-beam operation

Frequency Key: $a=$ annual, $n=$ "as-needed," $o=$ "one-time," $m=$ monthly, $q=$ quarterly

Responsibility Key: $\mathrm{P}=$ preparation, $\mathrm{R}=$ review, $\mathrm{C}=$ concurrence, $\mathrm{A}=$ approval, $\mathrm{I}=$ information only, In $=$ input 


\section{Appendix G}

\section{Key Decision 1 (Critical Decision 2) Approval Letter, October 1994}


The Secretary of Enèrgy

Wastington, DC 20585

MEMORANDUM FOR THE SECRETARY

THROUGH: Charles B. Curtis

Under Secretary

FROM :

Victor H. Reis

SUBJECT:

ACTION:

Approve Key Decision One for the National Ignition Facility

Since the May 24. 1994. Energy Systems Advisory Board meeting on the National Ignition Facility, the Department has conducted a wide ranging review of issues and concerns associated with prcceeding to the next stage of development of che facility. The issues examined in this context include concerns about the impact of the fucility on U.S. nonproliferation goals; contributions of the project to stockpile stewardship efforts and other science, technology and energy objectives of the Department: and envi ronmental. safety. heelth and budgetery considerations. Many of these issues. most notably the concern that construction of the facility may hinder U.S. nonproliferation objectives, have also been articulated by various individuals, nan-governmental organizations, and members of Congress.

The Department concurs that the issues identified above must be careluldy examined and thoroughly debated prior to a decision to proceed with construction of the facility. To that end. the Department hes endorsed an ongoing process of analysis and dialogue as proposed by the chairman of the House Armed Services Comittee, Congressman Ron Deliums, to satisfy concerns about outstanding issues. Specifically, the Dellums process will consist of the following elements:

(1) if a positive Key Decision One lauthorizing preliminary designl is taken, the Department agrees to establish a new milestone -- a Key Decision "One Prime" .- prior to making Key Decision Two (authorizing detailed design). The principal focus of Key Decision one Prime would be to resolve the question of whether or not the National Ignition facility will aid of hinder our nonproliferation efforts:

(2) an assessment that the mission and purpose of the facility remain timely and relevant:

(3) comprehensive stakeholder participation on issues of concern. especially nonproliferation; and 
(4) coordination with other agencies of the U.S. government necessary for carrying out the steps agreed to above.

The Department took the first step in implementation of this process through a workshop on the National Ignition Facility on september B. 1994, with representatives of Federal agencies, national laboratories, contractors, non-governmental organizations and advisory groups.

Besed upon careful consideration of information and viewpoints received to date, and subject to the conditions and requirements of the Dellums process, we conclude that it is appropriate to approve Key Decision One at this time. Approval of Kè Decision One w111 support the initiation of the National Environmental Policy Act process. as well as the establishment of a budget line item for Elscal year 1996 to support preliminary design work such as engineering studies, preliminary drawings, preliminary cost estimates and project scheduling.

The following assessments support the conclusion to epprove key Decision One at this time:

Missions

The National Ignition Facility has the potential to contribute siorificantly in the following misslon areas:

(1) Nuclear weapons physles: In the absence of underground testing, the National Ignition Facilicy would be critical tool for the Department's scierce-Baged stockpile stewardship progras. It would play an important role in maintaining the continued safety and reliability of the stockpile by creating experimental conditions thet approach certain aspects of nuclesr weapons physics. In particular. chis experimental capability would allow nuclear weapons scientists to assess stockpile problems, verify computational tools. and increase their understanding of weapons physics.

(2) Inetial fusion eneroy: The National Ignition Facility mould represent the scientifle culmination of more than 30 years of research in inertial confinement fusion. This type of Eusion concept focuses laser or particle beams on spherical targets causing them to implode, creating high temperatures and pressures necessary for these targets to burn. With the National Ignition Facility. scientists plan to achieve ignition (self-heating of the fuel) and fuel burn (more fusion eneroy produced then laser energy deposited) in the laboratory for the first time. Such an achievement could be an important step toward the development of fusion energy. The recent declassification of work in the inertial confinement fusion program would enable international 
cooperation on experiments at the National Ionition Facility.

(3) Science, technology, and other applications: The National Ignition Facility would be a "magnet" facility, attracting world-class scientists and engineers to work on problems of major importance to society: The ability to probe experimental conditions similar to those at the center of the sun and the stars would accelerate progress in basic sciences such as stellar physics and cosmology. In addition, as the world's largest precision optical instrument, the project would spur industriel capabilities. techrologies, and coumercial applications.

Cost and schedule

The facility would take approximately seven years to desion and build (fiscal years 1996 through 2002). with the total project cost estimated at $\$ 900$ million over the seven yeer period (1n fiscal yeer 1995 dollarbl. The ansual operating cost is expected to be about $\$ 60$ million. The total experimental operating lifetime of the facility is projected to be 15 year6, and cost $\$ 900$ million. Decomissioning and decontamination costs are estimated at $\$ 35$ million. This results in a life-cycle cost estimate of about $\$ 1.8$ billion.

\section{Nonproliferation}

Concerns have been expressed about the potential for the National Ignition Fecility to undermine $0 . S$. nonproliferation goals. In particular, some have argued that research at the facility would allow the $U$. S. to continue to desion and develop advanced new nuclear weapons concepts, thereby circumventing the prohibitions of a Comprehensive Test Ban Treaty. Others are concerned that access to the technologies or research data of the National Ignition Facility by non-nuclear weapon states could lead to horizontal proliferation. On the other hand, because of its contribution to the maintenance of a safe and rellable nuclear stockpile, the National Ignition Facility might further $0 . S$. nonproliferation oosis by speeding acceptance of a Comprehensive Test Ban by nuclear weopons states.

The Department believes that a policy of international collaboration and transparency for future experimentation at the facility could help dispel fears about a secret advanced U.S. weapons program, and thus assuage many of the nonproliferation concerns. The Department will further explore this approach of openness for the facility, and will resolve the broader range of nonproliferation issues within the Key Decision one Prime process. 
Safety and Enviromentel Anelygis

The Department hes completed a preliminary hazards analysis on the Nationad Ignition Facility followed by satecy, environmental. radiation protection. quality assurance, and decontamination and decomissioning assessments. The facility has been classified by the Department to be a low hazard, nonnuclear facility. The project will be reviewed in accordance with the National Environmental Policy Act to evaluate the safecy and environmental impacts from siting, construction and operation of the facility.

\section{siting}

The National Environmental Policy Act requires that any preference related to the siting of a facility be stated by the Department. Given the resident technical expertise and existing infrastructure at Lawrence Livermore National Laboratory. we believe that hivermore is preferable at.this time to other candidate sites. Accordingly, we would recomend that you announce the Departmental preference for Livermore if Key Decision one is epproved.

National Environmental Policy Act Process

Approval of Key Decision One obligates the Department to initiate the process of environrental review required under the National Environmental Policy Act. The Department intends to initiate a programmatic environmental impact statement on stockpile Stewardship and Management as a replacement to the now outdated programmatic EIS for reconfiguration. Since the National Ignition Facility. would be an important element of the stockpile stewardship program, we believe that the enyironmentel impact work on the proposed Nationel Igaicion Facility should occur within the larger framework of the programmatic environmental impact scatement for stockpile stewardship.

\section{Recommendation}

- Approve Key Decision One. which wi11: (1)initiace the Nationel Environmental Policy Act process for the facility; and (2) establish line item in the fiscal year 1996 budget to support preliminary planning, engineering, schedule and cost studies.

- Endorse the open and deliberarive process for further inquiry proposed by Congressman Dellums for proceeding to a key Decision One Prime prior to Key Decision Two.

- Announce that Lawrence Livermore National Laboratory is the Department's iseferred site for the National Ignition Facility. 
- Approve a Nalional Environmental Folicy AcL process that would include an examination of the National Ignicion Facility as part of a programatic environmental impact statement on stockpile stewardship and management.

APRROVED :

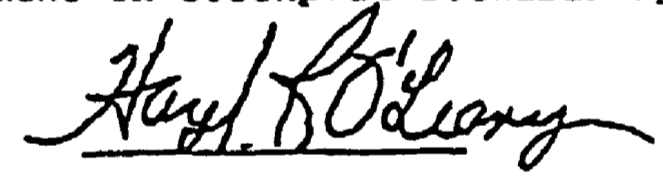

DISAPRROVED:

DATE :

October 20, 1994 


\section{Appendix $\mathrm{H}$}

\section{Approval of Baseline Change Action, March 1997}




\section{Department of Energy \\ Washingiton, DC 20585 \\ December 20, 1996}

MEMORANDUM FOR THE SECRETARY

THROUGH:

CHLARIES B. CURTIS

DEPUTY SECRETARY

THROUGH:

DONALD W. PEARMAN, JR /<smiles>C1=CCCCCCCCCCCC1</smiles>
ASSOCIATE DEPUTY SECRETARY FOR FIELD MANAGEMENT

FROM:

Victor H. Reis $i$

Assistant-Secretary for Defense Programs

SUBJECT:

ACTON: ACQUTSTTION EXECUTTVE APPROVAL OF BASEIINE CHANGE PROPOSAL FOR THE NATIONAL IGNITION FACLITY

ISSUE:

Acquisition Executive spproval is requested to adjust the cost and schedule baseline for the National Igaition Facility strategic system. If you approve the attuctied baseline change proposal, total project cost would be increased by \$125.3, million from \$1,073.6 million to $\$ 1,198.9$ milition, the total estimated cost of construction would be increased by $\$ 203.1$ million from $\$ 842.6$ million to $\$ 1,045.7$ million, and the completion date would be extended by twelve months.

BACKGROUND: The National Ignition Freility (NIF) is a key element of Defense Programs" scienco-based Stockpile Stewardship and Managerrent Program. This strategic system provides for design, construction and acceptance of a high-energy, high-power solid-state laser and target system for laboratory-zcale weapons physics experiments, inertial confinement fusion ignition and research, and applications of high energy dersity physics. Preliminary design is compiete and final design has started. The Record of Decision for the Stockpile Stewardship and Management Programmatic Environmeatal Impac Statement was issued on Deesmber 19, 1996 and the Lewrence Livermore National Laboretory, Liverwore, CA has been selected as the construction site. The proposed cost and schedule baseline changes have been recommended for approval to the Assistant Secretary of Defense Programs by the NIF Level I DOE Headquarters, Buseline Change Control Board. These changes extend the baseline completion date by 12 months (or 20\%) from the end of FYO2 to the end of FYO3, with an increase in the total project cost of $\$ 125.3$ million (or 11.7\%) from $\$ 1,073.6$ million to $\$ 1,198.9$ million. The total estimated cost of 
construction increased by $\$ 203.1$ million from $\$ 842.6$ to $\$ 1,045.7$ million. However, other project costs decreased by $\$ 77.8$ million, thus limiting the increase in the total project cost to $\$ 125.3$ million.

DISCUSSION:

The proposed baseline cost and schedule increases are a result of: (1) the changes to the project scope (described below) incorporated in the preliminary design (Title 1); (2) the expected annual funding availability in the five year period FY 1998-2002; and, (3) selection of the Lawrence Livermore National Laboratory as the NIF construction site.

The scope changes are:

- Facility user design requirements from the weapons program, weapons effects testing, and inertial fusion program needed to meet their programmatic missions.

- Site-specific infrastructure requirements for the Livermore construction site which were footnoted in the FY96 and FY97 Project Data Sheets.

- Title 1 design changes to meet operational and maintenance goals.

The changes to the total project cost associated with these scope changes is $\$ 74.3 \mathrm{M}$.

The remainder of the inerease, $\$ 51 \mathrm{M}$, is attributable to the extension of the baseline completion date by twelve months to Oct 2003. This was necessary to conform the project's annual funding requirements to expected DP funding availability during the five year period.

The NIF is a significant step beyond the state of the art in inertial confinement science, technology and facility size. The project has been well managed and progressed on schedule: Title I design has been completed and LLNL has been selected as the site. The baseline scope changes are to accommodate requests by the user community. These scope changes and normal maturation of the project drive the cost increase. The cost increase is not unreasonable and reflects a wellestablished science base and conceptual design. An Independent Cost Estimate (ICE) conducted by the Office of Field Management has validated the scope. The cost increase which resulted from the extension of the baseline schedule has not been examined by the ICE. 
SENSITIVITIES: $\quad$ This action establishes a new baseline cost and schedule for a highly visible Department science and technology initiative, especially under the revised OMB Circular A-II, part 3.

POLICY IMPACT: $\quad$ Action is consistent with current Department policy.

RECOMMENDATION: That you approve the recommended Baseline Change Proposal to:

-Increase the baseline total estimated cost of construction by $\$ 203.1$ million from $\$ 842.6$ million to $\$ 1,045.7$ million.

-Increase the baseline total project cost by $\$ 125.3$ million from $\$ 1,073.6$ million to $\$ 1,198.9$ million.

-Extend the baseline project completion date by tweive months from October 2002 to October 2003.

Attachment

APPROVE:

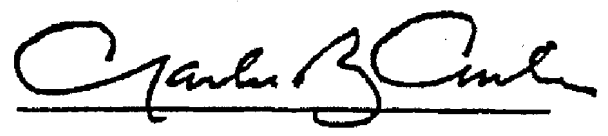

DISAPPROVE:

DATE:

March 7. 1997

Concurrences: General Counsel/Shebek for Nordhaus I/13/97

Policy/Chupka 1/12/97

Economic Impact/Moody 1/8/97

Human Resources/Tamura for Durtham 1/6/97

Chief Financial Officer/Smedley 1/13/97

Environment, Safety and Health/Brush for O'Toole $\mathrm{l} / 14 / 97$

Environmental Management/Alm (undated)

National Security/Baker 1/17/97

Congressional/Alcock for Forrister 12/27/96 


\section{Appendix I}

\section{Critical Decision 3 Approval Memorandum,} March 1997 
Department of Energy

Wastinglon, DC 20585

Februasy 6, 1997

\author{
ivit-uUnaro \\ WBS1.1.1.1 \\ 1997-003201
}

HAli 1 I 1997.

MEMORANDUM FOR THE ACTING SECRETARY

THROUGH:

FROM:

SUEIECT:

iSSUE:

BACKGROLND:
Charier B. Curtis

Deputy Secretary

Victor H Reis UAtre-

Assistant Secretary for Defense Programs

ACTION: Memorandum to the Energy Systems Acquisition Advisory Board Acquisition Executive requesting approval of Critical Decision 3 (CD-3), Start of Construction for the National Igrition Facility (NIF).

The Department's project maragement system process and OMB Circular A-109, require that the Secretary, as the hequisition Exective, approve CD-3, before the NIF can proced to its next phase, the start of construction. It is critical that $\mathrm{CD}-3$ is approved before March to prevent costly stippage in schedule.

The National Igaition Facility is a key element of Defense Programs' science-based Stoclpile Stewardsbip and Manageneat Program. This Strategic System provides for desiga, construction and acepptance of aigh-eaergy, high-power solid-state laser and target system for laboratory-scale weapous physios experiments, inetial confinement fusion igaition and research, and applications of high energy density phystes.

All prerequisite Critical Decision milestones, previously called Koy Decisions (KDs), trave been approved. These incluáe KD 10 (now $C D$ 1), Approval of Mrission Neod (Reference 1), approved by Secretary Wattias on Jamury 15, 1993; TDL-I (now CD-2), Approval of New Start (Reference 2), epproved by Secretary O'Leary on Oetober 20, 1994; and, KD-I' (prime) (Reference 3), an added decision milestone, approved by Secretary OTeary on Decuber 20, 1995. Approval of KD-I' was based on the finding that the techrical protiferation concens at the NIF were manugeable and, therefore, could be made acceptable, and the NIF could contribute positively to U.S. arms control and nonproliferation policy gouls. The Secretary delegated authority to approve the Project Exeeution Plan to the Assistant Secretary on June 14, 1996 (Refereace 4). The Mission Need was reconfimed at each successive milestone. 
The Record of Decision for the Stockpille Stewardstip and Manzgement Programmatic Environmental Impact Statement (Reference S) was issued by Secretary O'Leary on Decernber 19, 1996. Lawrence Livermore National Laboratory has been seleeted as the construetion site. The Preliminary Safety Analysis Report (Reference 6) categorizes the NIF as a low hazard, radiological facility. DOE-OAK approved this report on October 3, 1996, in the Safety Evaluation Report on the Lawrence Livermore National Laboratory.

The NIF project has completed pretiminary design (Title I) which added project scope changes to the conceptual design completed in May, 1994. These changes included: (1) facility user requirements from the weapons physics, the radiation effects testing. and the inertial fusion programs; (2) site-specific infrastructure requirements (previousily only footnoted in the Project Data Sheet pending site selection); and, (3) design requirements to meet operational and maintenance goals. An independent design review committee conducted a detailed technical assessment of the preliminary design and in their Summary Report of December 9, 1996. (Reference 7), recounnended proceeding with detailed engineering design (Title II), major long-lead procurement and site preparation. The NIF preliminary design formed the basis for DOE Field Management's independent Cost Estimate (Reference 8) which was within 1 perceat of the project's estimate. This constitutes excellent agreement and validates the NIF cost baseline for proceeding with fmal design. Final design and planning for the start of construction are proceeding in accordance with approved fiscal year 1997 plans.

Congressional funding for the NIF project in fiscal years 1996 and 1997 provided the Department's full requests. The 1997 appropriation included funding for site preparation and early construction plansing. The Department's fiscal yesr 1998 budget submission, including the NIF Project Data Sheel requests full appropriation for the remaining funds necessary to complete construction of the NIF. The Project Dats Sheet incorporates the scope changes discussed above and associated cost and schedule charges. These changes: (1) extend the baseline completion date by one year from the end of fiscal year 2002 to the end of fiscal year 2003; (2) inerease the Total Project Cost from \$1,073.6 million to \$1,198.9 million, an increase of $\$ 125.3$ million; and, (3) are consistent in timing with overall program needs and capabitity and with anticipated obligational authority targets for Deferse Programs for fiscal year 1998 and beyond. These seope, cost and schedule baseline changes were approved through the Level I NIF Baseline Change Control Board and subsequently concurred with by the Energy Systems Acquisition Advisory Board members, as a Level 0 sction (Reference 9), on January 16, 1997. Final approval by the Acquisition Executive has been requested. 
SENSTTIVTTIES: As of 2/19/97: On February 14, 1997, a lawsuit was filed naming DOE and the Nationsi Academy of Sciences (NAS) as defendunts. The suit seeks among other things, to enjoin DOE from ralying on a National Acedemy of Sciences Inertial Confinement Fusion technical review panel in muking its dectsion to start construction (CD-3) becuse, it alleges, DOE is in violation of the Federal Advisory Committee Aet (FACA). While the NAS bnal report is expected in eariy Merch DP has resched its tecturical conclusions without the NAS panel report. The Office of General Counsel concurs with DP and has no legal objection to DP's intention to proceed with CD-3.

POLICY IMPACT: Action is consistent with current Department policy.

RECOMDIENDATION: Approve Critical Decision 3, Start of Construction for the NIF.

APPROVE:
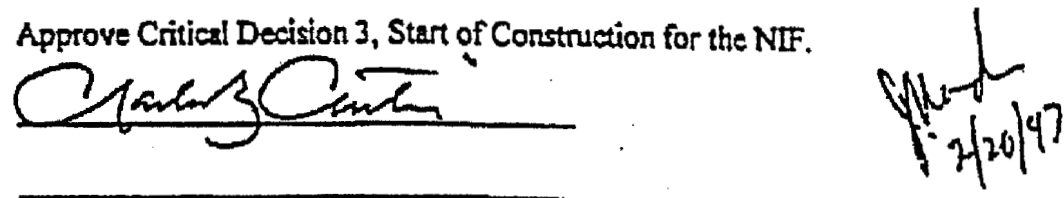

DISAPPROVE:

DATE:

varch 7. 1997

The Energy Systems Acquisition Advisory Board Secretariat, Field Management, has received concurrences from all menbers of the Board.

Policy/Chuipka Undated

Economic Iropact/Moody 2/4/97

Human Resources/Tamura for Durtam 2/21/97

Chief Financial Officer/Smedley 2/21/97

Exvironment, Sxety and Healti/Brush for O'Toole 2/24/97

Emironmentel Management/Alm .Undated

National Secunity/Baker 2/21/97

Congressionat/Forister Unduted

General CourasedJohnston 2/19/97

Sullivan 2/19/9y

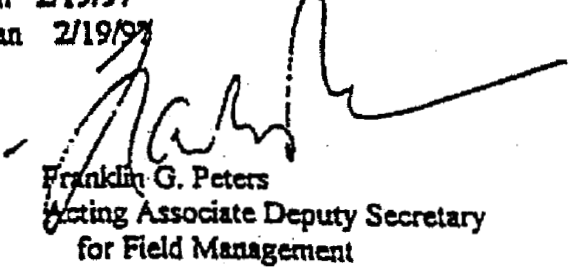




\section{Appendix J}

NIF Functional Requirements and Primary Criteria 


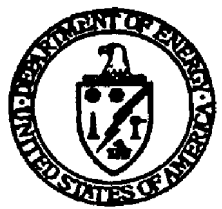

MAY U I IYYI

\author{
Department of Energy \\ Oakland Operations Office \\ 1301 Clay Street \\ Oakland, Califomla 94612-5208
}

APR 291997

Dr. Jeffrey A. Paisner

NIF Project Manager

Lawrence Livermore National Laboratory

P.O. Box 808, L-488

Livermore, Ca. 94550

Subject: Close-out of the Baseline Change Proposal 97-004

Dear Dr. Paigner: |I|)

Baseline Change Proposal (BCP) 97-04, incorporating minor changes to the "NIF Functional Requirements and Primary Criteria," has been approved by the level 1 Baseline Change Control Board. As you recall, appoval of BCP 97 04 was delayed, pending completion of the Work Smart Standards (WSS) Process Document. The WSS Process Document was submitted to the Level 1 BCP, and approved on March 20, 1997, closing-out BCP 97-04.

Following approval of the BCP 97-04, the Functional Requirements and Primary Criteria (FRPC) were was submitted to Dr. James Turner for approval. His approval was received on April 4,1997. In order to make the FRPC the official requirements for design and construction of the NIF, I have requested that the FRPC be included into the University of California Contract (DE-AC03-76SF00048). On April 18,1997 a letter was sent to Mr. Ronald Nelson from the DOE Contracting Officer requesting that the FRPC be applied to the contract for design and construction of the NIF. The FRPC, once incorporated into the contract, define the requirements and standards to be used for design and construction of the NIF, and will replace DOE environment, safety and health orders specified in Appendix G, Section I for the NIF only.

Enclosed is a copy of the approved FRPC and the WSS Process Document. Please distribute copies of the final FRPC to the following organizations:

1. DOE Headquarters, DP-18 (3 copies)

2. NIF DOE Field Office, ICFD (15 copies)

3. Level 1 BCCB Secretary, (1 copy) 


\section{Dr. Paisner \\ Page 2}

Thank you for your efforts in closing out BCP 97-04. If you have any questions, please call me at (510) 423-0593.

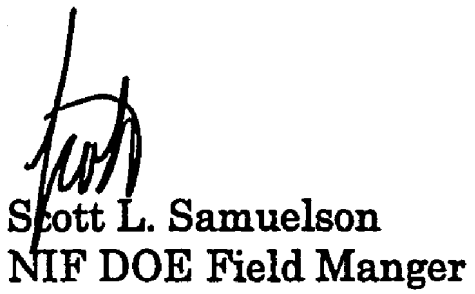

Enclosures:

cc: Jon Yatabe, Level 3 BCCB 
memorandum

\author{
DAre: APR 031997 \\ AтTм OF: Oakland Operations Office (ICFD) \\ sUBAecr: Functional Requirements and Primary Criteria for the NIF \\ To: James M. Turner, Ph.D, Manager
}

Attached are the Functional Requirements and Primary Criteria (FRPC) for the National Ignition Facility (NIF) and the Work Smart Standards (WSS) Process Document. The FRPC establishes the scientific and engineering requirements that must be met during design and construction of NIF. The WSS Process Document, documents the process used to develop the FRPC.

The requirements identified in the FRPC for construction of NIF replace the set of standards that currently exist in the DOE/UC contract. When construction is complete the NIF will operate under the set of requirements established as a part of the WSS process that is currently under way at LLNL.

A Contracting Officer's Directive will be issued by LCMD that incorporates the FRPC into contract 48 . These requirements will be in effect for the entire construction period.

In the absence of an established OAK policy for approval of standards and requirements under the Work Smart Standards process, I believe it is appropriate for you to approve this set of standards, prior to our issuing the C.O. Directive. Please indicate your decision by signing below. 
Should you have any questions, or if you desire a briefing prior to making your decision, please contact me.

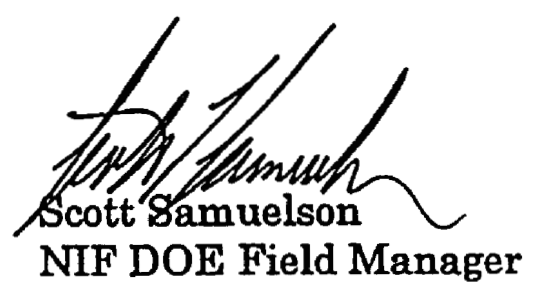

Action:

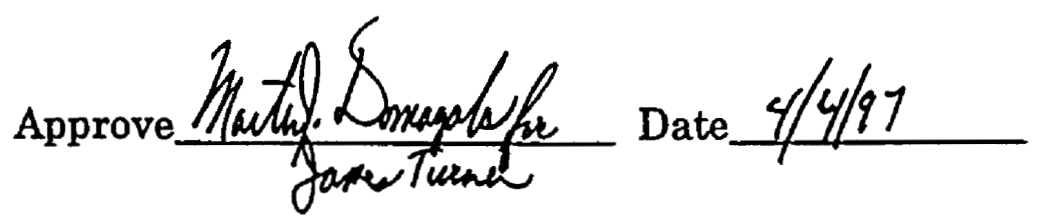

Disapprove

Date

cc: C. Taylor 

National Ignition Facility

Funcional Requirements

and Primary Criteria

Revision 1.6

March 1997

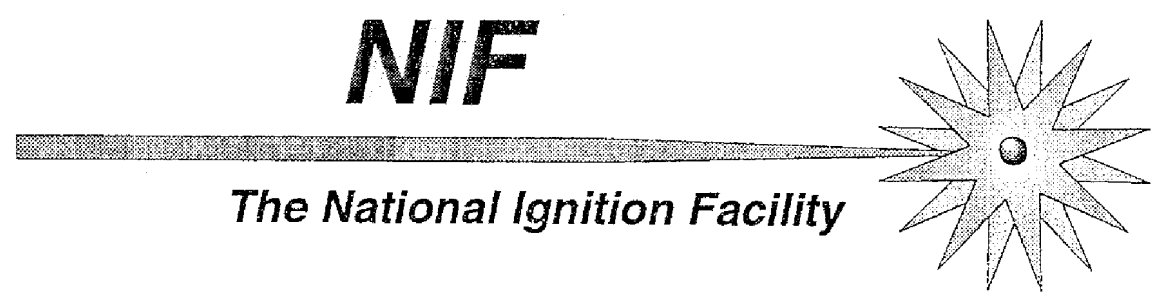



NIF Functional Requirements and Primary Criteria

Rev. 1.6

Approval Sheet

NIF Project Manager

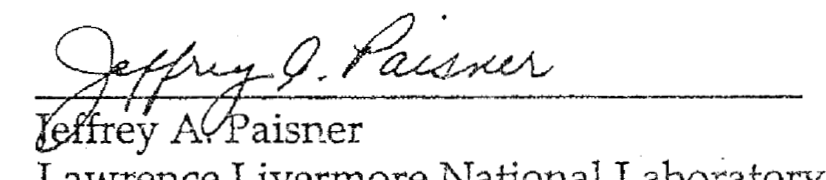

Lawrence Livermore National Laboratory

NIF DOE Field Manager

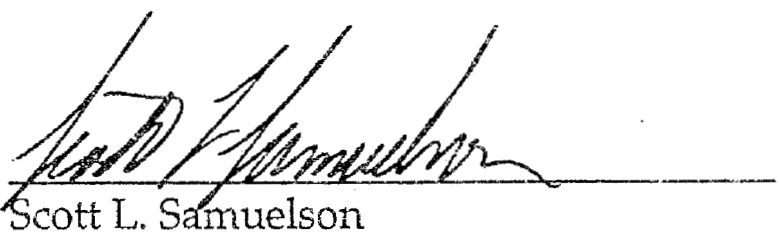

Oakland Operations Office

Director, Office of the National Ignition Facility

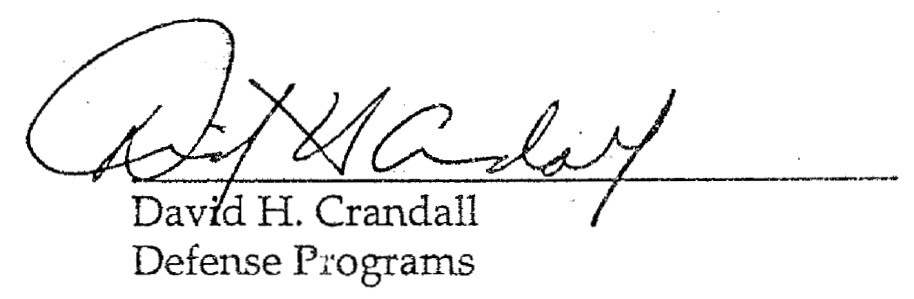





\section{Table of Contents}

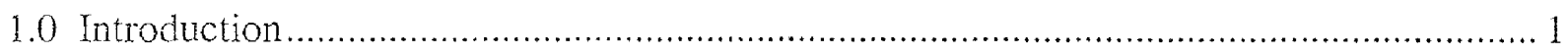

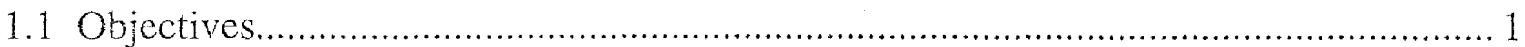

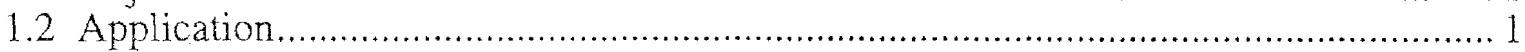

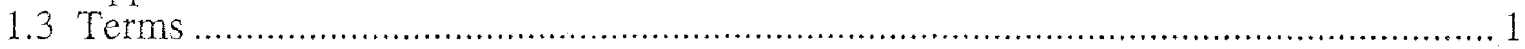

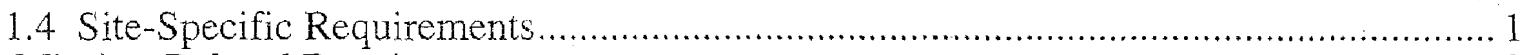

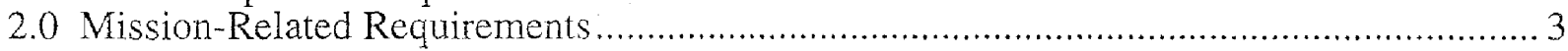

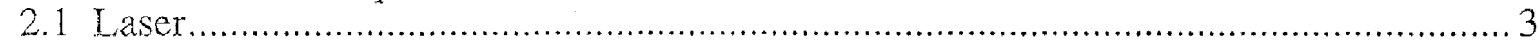

2.1.2 Laser Pulse Peak Power* ........................................................................ 3

2.1 .3 Laser Pulse Wavelength* .............................................................. 3

2.1.4 Beamlet Power Balance *....................................................................... 3

2.1.5 Beamlet Positioning Accuracy* ............................................................ 3

2.1.6 Laser Pulse Duration ..................................................................... 3

2.1.7 Laser Pulse Dynamic Range ................................................................... 3

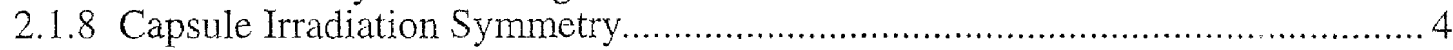

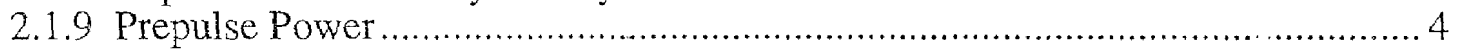

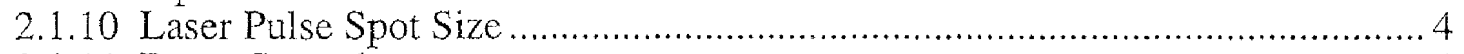

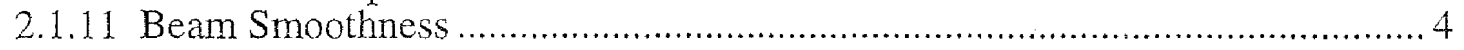

2.1.12 Direct-Drive Requirements *.............................................................. 4

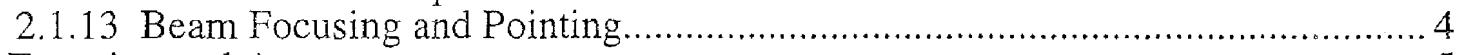

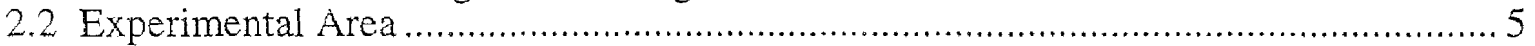

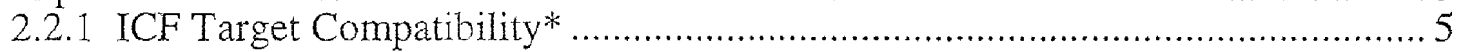

2.2.2 Annual Number of Shots with Fusion Yield for Chamber Design* ................. 5

2.2.3 Maximum Credible DT Fusion Yield*.................................................... 5

2.2.4 Classification Level of Experiments * .................................................... 5

2.2.5 Target Positioner.................................................................................. 5

2.2.6 Time Between Shots with No Fusion Yield ............................................ 5

2.2.7 Target Chamber Vacuum Capability ........................................................ 5

2.2.8 Diagnostic Instrument Capabilities to Verify Laser Performance...................... 6

2.2.9 Diagnostic Instrument Capabilities for Ignition and Applications

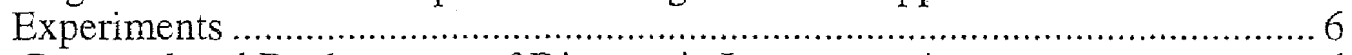

2.2.10 Removal and Replacement of Diagnostic Instruments* ..............................6 6

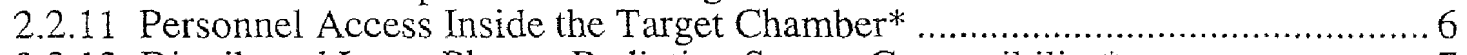

2.2.12 Distributed Laser Plasma Radiation Source Compatibility * .......................... 7

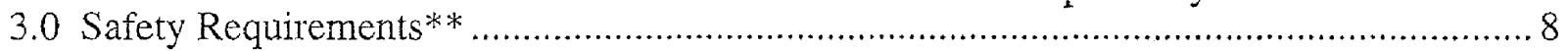

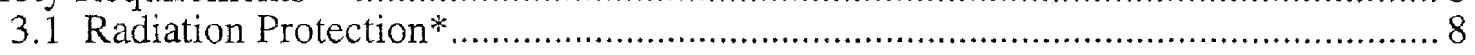

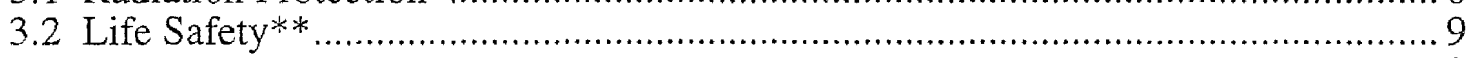

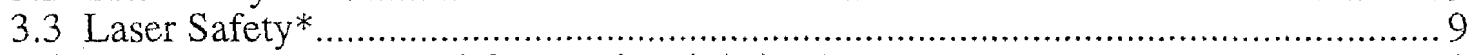

3.4 Industrial Hygiene and Occupational Safety* .......................................... 9

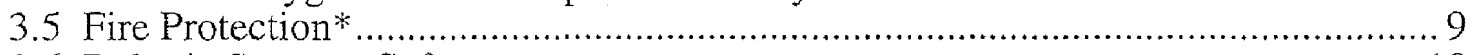

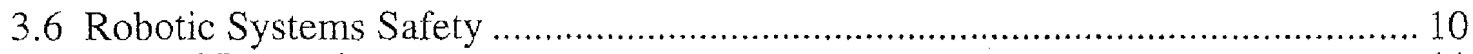

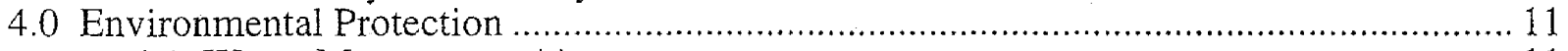

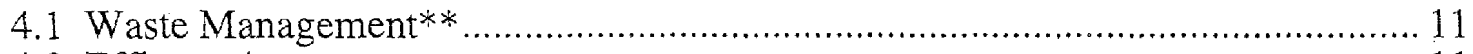

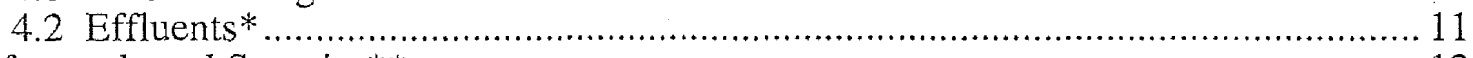

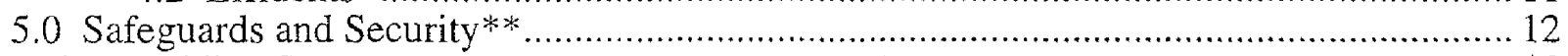

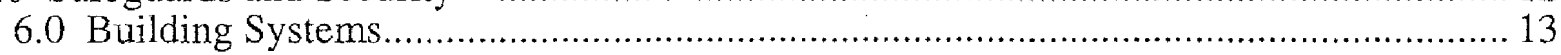

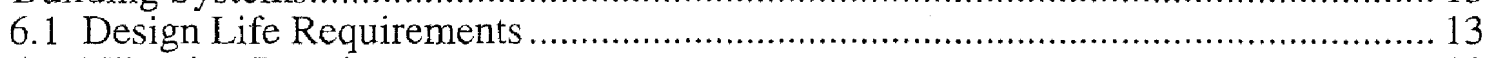

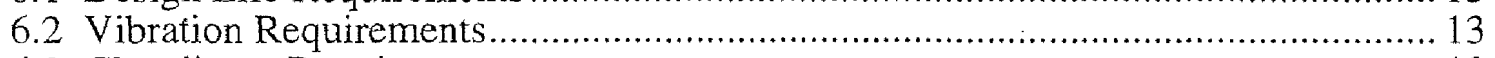

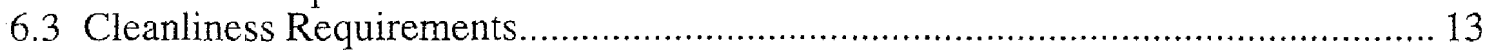




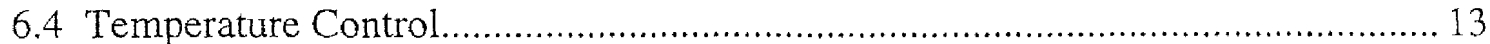

6.5 Electrical Power...................................................................................... 14

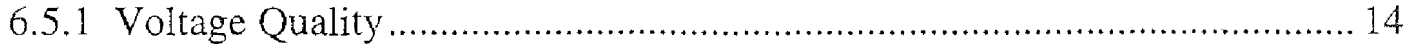

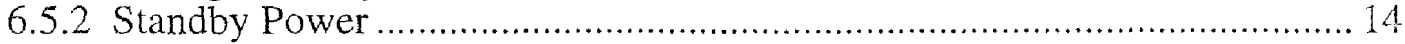

6.5.3 Uninterruptible Power .................................................................... 14

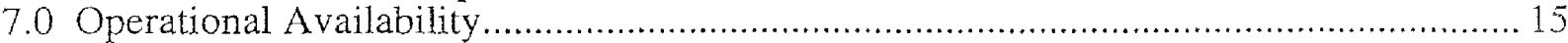

7.1 Reliability, Availability and Maintainability (RAM)* ............................... 15

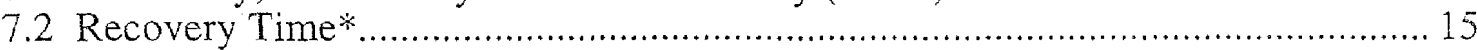

8.0 Decontamination and Decommissioning ...................................................... 17

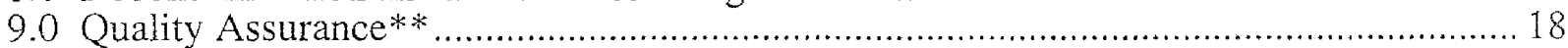

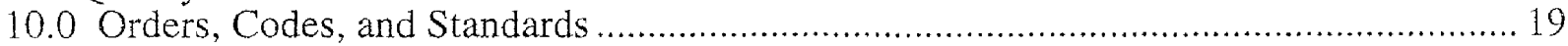

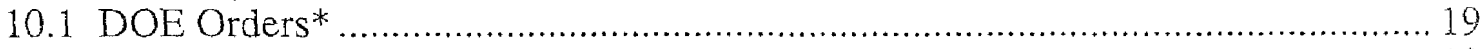

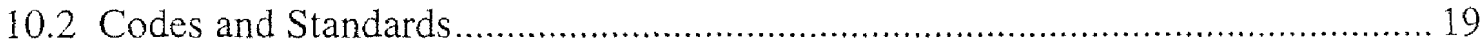

10.3 Applicable Orders, Codes, and Standards ..................................................... 19

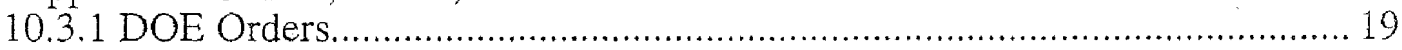

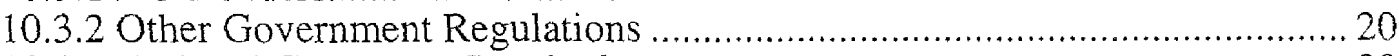

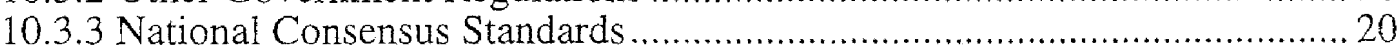




\subsection{Introduction}

\subsection{Objectives}

This document establishes the scientific and engineering requirements that must be achieved by the National Ignition Facility (NIF). The process used for developing these requirements is described in "Process for the Development of the NIF Primary Criteria and Functional Requirements," NIF-0001566, March 1997. Mission goals, as defined in the Justification of Mission Need, are translated into laser power, laser beam characteristics, and other performance specifications. Top-level operability, safety, and environmental requirements are defined and discussed. Finally, key requirements that must be met to satisfy Department of Energy (DOE) Orders, state, and federal regulations, national consensus standards and preferred procedures are highlighted to help ensure that they are incorporated by the design teams.

\subsection{Application}

The Functional Requirements and Primary Criteria serves as a technical baseline for the Project. Any modifications must be processed through the change control mechanism specified in the NIF Project Execution Plan and implementing procedures and formally approved. Each individual requirement or criterion has been placed in one of two hierarchy levels for control purposes. Those items which are Level 1, Primary Criteria, are marked with either a single or double asterisk and are controlled by DOE Headquarters. Nonasterisked items are classified as Level 2, Functional Requirements, and are controlled by the NIF DOE Field Manager. The control of double-asterisk requirements may be delegated to the NIF DOE Field Manager at some point in the future as part of the ongoing decentralization process.

1.3 Terms

The terms "should" and "shall" have important implications beyond what might be implied by common usage. "Shall" denotes a requirement that is mandatory and must be met. "Should" denotes a nonmandatory recommendation or goal.

1.4 Site-Specific Requirements

These requirements are applicable to the LLNL site, selected by the DOE in the Record of Decision for the Programmatic Environmental Impact Statement for Stockpile Stewardship and Management. 
2.0 Mission-Related Requirements

The laser system shall be designed to meet the following requirements simultaneously, although all performance requirements need not be demonstrated simultaneously on a single event.

2.1 Laser

2.1.1 Laser Pulse Energy*

The laser shall be capable of routinely producing a temporally-shaped pulse of energy at least 1.8 million joules (MJ) incident on the entrance hole of the target hohlraum.

2.1.2 Laser Pulse Peak Power*

The laser shall be capable of producing a pulse with peak power of at least 500 trillion watts (TW).

2.1.3 Laser Pulse Wavelength*

The wavelength of the laser pulse delivered to the target shall be 0.35 mirrons $\left(\_\mathrm{m}\right)$. The design should not preclude delivering $0.53 \_\mathrm{m}$ and $1.05 \_\mathrm{m}$ wavelength light to the target with reasonable modifications.

2.1.4 Beamlet Power Balance*

The rms deviation in the power delivered by the laser beams from the specified power shall be less than $8 \%$ of the specified power averaged over any 2 nanosecond (ns) time interval.

2.1.5 Beamlet Positioning Accuracy*

The rms deviation in the position of the centroids of all beams from their specified aiming points shall not exceed 50 micrometers (_m) at the target plane or its equivalent.

2.1.6 Laser Pulse Duration

The laser shall be capable of producing a pulse with overall duration of up to $20 \mathrm{~ns}$. 2.1.7 Laser Pulse Dynamic Range

The laser shall be capable of delivering pulses to the fusion target with a dynamic range of at least 50:1, where the dynamic range is defined as the ratio of intensity at the peak of the pulse to the intensity in the initial "foot" portion of the pulse. 


\subsubsection{Capsule Irradiation Symmetry}

Variations in the $x$-ray energy deposited on the fusion capsule, located in the target hohlraum, should be $\leq 2 \%$ rms. Current target design and performance calculations indicate that this level of irradiation uniformity can be achieved by two-sided laser illumination of the hohlraum. Multiple laser beams on each side enter the hohlraum along two concentric cones with cone half-angles of approximately 27 degrees and 53 degrees, and with two-thirds of the beams on the outer cone and the remaining onethird on the inner cone. Each cone shall consist of 8 or more beams. The capability shall be provided for the pulse shape delivered by beams on the inner cone to be different from the shape delivered by those on the outer cone.

2.1.9 Prepulse Power

The laser intensity delivered to the target during the 20-ns interval prior to arrival of the main laser pulse shall not exceed $108 \mathrm{~W} / \mathrm{cm} 2$.

2.1.10 Laser Pulse Spot Size

Each beam shall deliver its design energy and power encircled in a 600 _m diameter spot at the target plane or its equivalent. In the appropriate configuration, each beam should deliver $50 \%$ of its design energy and power encircled in a $100 \_\mathrm{m}$ diameter spot at the target plane or its equivalent.

\subsubsection{Beam Smoothness}

The NIF shall have spatial and temporal beam conditioning to control intensity fluctuations in the target plane.

\subsubsection{Direct-Drive Requirements*}

Future upgrade to meet the following requirements, specific to direct-drive experiments, shall not be precluded in the baseline NIF design.

2.1.12.1 Direct-Drive Irradiation Symmetry. Direct-drive ICF targets shall be irradiated by three pairs of concentric cones, with midplane symmetry. The cone halfangles and number of beams on each cone shall be:

Direct-drive cone Cone half-angle (approximate) Fraction of total beams

Inner same as indirect drive $1 / 6$

Outer same as indirect drive $1 / 3$

Waist 75 degrees $1 / 2$

\subsubsection{Beam Focusing and Pointing}

The NIF should have flexibility in beam focusing and pointing to address the needs of radiation effects testing and other users. 


\subsection{Experimental Area}

The National Ignition Facility shall be operated in a manner consistent with its role as a national resource. Whenever possible, the design shall accommodate the requirements of users with diverse needs. The baseline facility design shall not preclude future addition of target chambers for additional weapons physics and/or radiation effects testing. The baseline design and operation should be capable of performing radiation effects testing of important national assets, up to system level components, to maintain and certify their reliability. The following requirements are intended to satisfy the most basic of these needs.

\subsubsection{ICF Target Compatibility*}

The target chamber and target area support systems shall be capable of target operations with both cryogenic and noncryogenic targets containing fusion fuel. Provisions shali be made to accommodate and support experimenter-supplied cryostats for cryogenic targets.

2.2.2 Annual Nimber of Shots with Fusion Yield for Chamber Design*

The NIF shall be capable of performing yield shots with total DT fusion yield of 1200 $\mathrm{MJ} /$ year. The NIF shall be capable of performing up to 50 shots per year with a routine DT fusion yield of $20 \mathrm{M}$ ). The NIF design shall provide for life-cycle-cost-effective future addition of components that are needed only for high yield operations and are therefore not needed in the first three to five years of operations, such as shield doors and decontamination equipment.

\subsubsection{Maximum Credible DT Fusion Yield*}

The target chamber shall be designed based on routine DT fusion yield of $20 \mathrm{MJ}$, with the capability to withstand a DT fusion yield produced by a single shot of up to $45 \mathrm{MJ}$ (a $45 \mathrm{MJ}$ yield corresponds to 1.6 _. 1019 neutrons).

2.2.4 Classification Level of Experiments*

The facility shall be designed to allow both classified (at the SRD level) and unclassified experiments. Its design should permit changing classification levels with minimal impact on operations and cost.

\subsubsection{Target Positioner}

The target positioner shall be capable of placing and holding targets within $3 \mathrm{~cm}$ of target chamber center, with accuracy, repeatability, and stability consistent with the relative laser/target alignment specified in Section 2.1.5 and operations specified in Section 2.2.1.

2.2.6 Time Between Shots with No Fusion Yield

To address the needs of indirect-drive, direct-drive, and other users, the laser and experimental area shall be capable of conducting no fusion yield experiments with a time between shots of 8 hours, with a goal of 4 hours.

\subsubsection{Target Chamber Vacuum Capability}

The target chamber shall be capable of achieving a vacuum level of $<1$ _ $10-5$ Torr. 


\subsubsection{Diagnostic Instrument Capabilities to Verify Laser Performance}

The facility shall have the following measurement capabilities that are required to verify the Primary Criteria and Functional Requirements:

- Laser pulse energy and power.

- Laser pulse duration and dynamic range.

- Laser beam power balance.

- Simultaneity of arrival of pulses from individual beamlines at target chamber center with 10 ps accuracy.

- Laser beam pointing accuracy with 10-20 micron spatial resolution.

- Laser prepulse intensity.

- Laser pulse spot size.

- Laser pulse smoothness.

- Laser beam thermal recovery time.

\subsubsection{Diagnostic Instrument Capabilities for Ignition and Applications Experiments}

The target chamber and area shall be capable of accommodating diagr ostic instruments for the following measurements necessary for fusion ignition and applications experiments:

- Symmetry of x-ray emission from imploded cores with 5- to 10-micron spatial resolution.

- Motion of the x-ray emitting volumes in hohlraums with 20 micron spatial resolution.

- Laser light backscattered into the focusing lens.

- Radiation flux out of hohlraums within the photon energy range $0.15-2.5 \mathrm{keV}$ with 100-ps time resolution and $20 \%$ accuracy.

- Strength of radiation driven shocks with 5- to 10-micron resolution and time resolution of $10 \mathrm{ps}$.

- Fusion yield over a range from 1011 to 1019 neutrons.

- Symmetry of neutron emission from imploded cores with 20-micron spatial resolution.

- Temperature of the compressed fusion fuel with $20 \%$ accuracy for ion temperatures of $2 \mathrm{keV}$ or greater.

- Number and energy distribution of fast electrons in hohlraums in the band from $5 \mathrm{keV}$ to $300 \mathrm{keV}$.

- Radiation flux out of hohlraums within the photon energy range $2.5-100 \mathrm{keV}$ with $20 \%$ accuracy.

\subsubsection{Removal and Replacement of Diagnostic Instruments*}

Rapid removal and replacement of diagnostic instruments consistent with the shot frequency specified in Section 2.2.6 shall be accomplished by diagnostic inserters and manipulators for close-in target diagnostics. 


\subsubsection{Personnel Access Inside the Target Chamber*}

Personnel access to the inside of the target chamber shall be consistent with requirements for periodic cleaning necessary to maintain radiological, low-hazard, nonnuclear operations and for inspection and maintenance consistent with operational requirements.

\subsubsection{Distributed Laser Plasma Radiation Source Compatibility*}

The NIF should provide the basic capability to allow laser irradiation of distributed target arrays with future upgrade. The target chamber should allow flexibility in beam dump placement. 


\subsection{Safety Requirements**}

The NIF shall be designed, constructed, and operated as a radiological low-hazard facility. Compliance with this classification shall be verified through a Preliminary Hazard Analysis assessment of bounding accidents involving those radionuclides and/or chemicals presenting the most significant hazards (see DOE Order 5481.1B, Safety Analysis Review System). Administrative controls shall be established prior to the first use of tritium-bearing targets to ensure that inventory limits for a low-hazard radiological facility are not exceeded.

\subsection{Radiation Protection*}

Collective and individual ionizing radiation doses to the public from all exposure pathways from the NIF shall meet the requirements of DOE Order 5400.5, Radiation Protection of the Public and the Environment, and 40 CFR 61, National Enission Standards for Emissions of Radionuclides Other Than Radon from Department of Energy Facilities. These requirements state that exposure of members of the public from emissions of radionuclides in the ambient air from normal NIF operations shall remain below $10 \mathrm{mrem} / \mathrm{y}$. The facility shall also meet the requirements of DOE Order 5400.5 to not cause the public dose from all exposure modes and all sources of radiation at the site boundary to exceed $100 \mathrm{mrem} / \mathrm{y}$.

The NIF personnel radiation protection program shall follow DOE Order N441.2. Radiation Protection for Occupational Workers and 10 CFR 835, Occupational Radiation Protection. The ALARA (as low as reasonably achievable) principle shall be utilized in both design and operation of the facility to eliminate unnecessary radiation dose to workers in the Laser and Target Area Building, collocated employees, and visitors from both routine and off-normal operations. Radiation protection shall include: shielding; control of workplace ventilation; monitoring of personnel for external and internal radiation dose; establishment of a routine contamination monitoring program including air monitoring; and the proper containment of radiation and radioactive materials.

The radiation shielding design limit the maximum doses to an individual worker to one- tenth (shielding design goal) of the occupational external dose limits specified in 10 CFR 835. Concrete shielding shall comply with ACI 301, which provides adequate strength for DBE loads.

The requirements for radiological safety in 10. CFR 835, Occupational Radiation Protection, should be evaluated by the designers and incorporated when they are determined to be cost effective, even though the Projected inventory of tritium in NIF $(\sim 0.05 \mathrm{~g}$ or $500 \mathrm{Ci})$ is well below the threshold for a nuclear facility. The target chamber and tritium processing systems shall form the primary confinement barrier. Leakage past these barriers shall be ALARA. The experimental-area ventilation system shall be 
designed to operate at negative pressures during and immediately after shots of greater than one megajoule and provide secondary tritium confinement.

The final exhaust release point from this system should be elevated for dispersion. Exhaust air shall be continuously monitored for radioactivity. The target area shall also. be monitored to ensure that radiological conditions are safe for personnel entry.

\subsection{Life Safety**}

The NIF shall fully comply with the requirements for life safety contained all National Fire Protection Association (NFPA) Codes. Particular focus shall be directed towards features related to the means of egress, such as protection of vertical openings, travel distances, capacities, and emergency lighting.

\subsection{Laser Safety*}

The laser safety shall comply with ANSI Z136.1. Exposure to hazardous levels of laser light shall be prevented by the use of physical barriers, personnel training, interlocks, and personnel entry controls. Protective equipment, such as iaser goggles, shall be used when necessary for operational purposes. Interlock systems shall be dedicated and designed to be fail-safe and shall activate laser shutters or shut off power to laser systems if access doors are opened and hazardous exposures are possible.

\subsection{Industrial Hygiene and Occupational Safety*}

Industrial hygiene and occupational safety shall comply with 29 CFR 1910 Occupational Safety and Health Act (OSHA) - Operation. Construction safety shall comply with the requirements of 29 CFR 1926, OSHA- Construction.

Facility subsystems (e.g., capacitor banks, vacuum systems, tritium recovery, nitrogen supply, and personnel safety interlock systems) shall be designed to default to a safe state upon loss of power.

\subsection{Fire Protection*}

The NIF shall meet the design and fire protection requirements, all NFPA Codes and the Uniform Building Code (UBC). The structural members of the Experimental Building (including exterior walls, interior bearing walls, columns, floors, roofs, and supporting elements) shall, as a minimum, meet UBC fire-resistive standards. Appropriate fire barriers shall be provided to limit property damage, fire propagation, and loss of life by separating adjoining structures, isolating hazardous areas, and protecting egress paths. The NIF shall meet the requirements for an "improved risk" level of fire protection sufficient to attain DOE objectives. To achieve this level of protection, automatic fire sprinklers shall be installed throughout the complex. The sprinklers shall be coupled with adequate fire protection water supplies and automatic and manual means for detecting and reporting incipient fires. Fire hazard analyses will be completed as required by all NFPA Codes. 


\subsection{Robotic Systems Safety}

Robotic systems shall comply with the requirements of ANSI/RIA R15.06-1992; Industrial Robots and Robot System-Safety Requirements. 


\subsection{Environmental Protection}

\subsection{Waste Management**}

The NIF shall minimize the generation of wastes at the source per: DOE Policy P450.1, Environmental Safety and Health Policy for the Department of Energy Complex, General Environmental Protection Program, and DOE Order 5820.2A, Radioactive Waste Management; and the Resource Conservation and Recovery Act (USC 6901 to 6992); and the Toxic Substances Control Act (USC 2601-2692). The NIF waste handling areas shall comply with the standards of confinement and ventilation requirements specified by DOE Order 5820.2A, Radioactive Waste Management.

The NIF will generate hazardous waste, low-level radioactive waste (LLW), and mixed (LLW and hazardous) waste. These wastes shall be collected in approved containers, lapeled, packaged, sorted, and shipped to an EPA/DOE-approved treatment or disposal site according to the Resource Conservation Recovery Act and the following regulations: hazardous waste per 40 CFR 260, 261 and 262; low-level waste per DOE Order 5820.2A; and mixed (LLW and hazardous) waste per DOE Order 5820.2A, and 40 CFR 260. The LLW packages shall meet the radioactive solid waste acceptance criteria of the final approved disposal site. Pollution prevention will be considered in the NIF design as required by DOE Order 430.1.

\subsection{Effluents*}

Liquid effluent discharges from NIF discharge points shall be monitored and controlled in compliance with 10 CFR 835, DOE Order 5400.5, Radiation Protection of the Public and the Environment; the Clean Water Act (33 U.S.C. 1251 et seq.); and by conditions on 40 CFR 125 Criteria and Standards for National Pollutant Discharge Elimination System.

Air emissions shall meet the requirements of Section 3.1 (radiation shielding and confinement) for radionuclides and the requirements of the Clean Air Act, (42 U.S.C. 7401) including National Emission Standards for Hazardous Air Pollutants (NESHAP), and state and local air quality management district requirements. 


\subsection{Safeguards and Security**}

The NIF safeguards and security features shall meet the requirements of DOE Order 5632.1C, Protection of Safeguards and Security Interests, and DOE Order 470.1, Safeguards and Security Program. These requirements include physical protection of classified data and equipment and items in use and in storage. For the facility security areas and access control, requirements shall be established based on the nature of experiments (i.e., classified or unclassified) being performed. The limited areas shall be the target area, target receiving and inspection, final target alignment, classified data acquisition, and office areas where classified computing is performed. Automated Data. Processing (ADP) systems handling classified information shall meet the requirements of DOE Orders 5637.1, Classified Computer Security Program, and 5300 D, Telecommunications: Protected Distribution Systems. Elements of DOE Orders 470.1, Safeguards and Security Program, and 472.1, Personnel Security Activities, will also be incorporated into the security plan.

The NIF complex shall also meet the requirements for physical protection of DOE property and unclassified facilities, protection program operations, and personnel security, including issuance, control, and use of badges, passes, and credentials.

Because the continuous operation of the NIF is not required to prevent adverse impacts on national security or the health and safety of the public, it is not classified as a vital facility, per DOE Order 5632.1C. 


\subsection{Building Systems}

\subsection{Design Life Requirements}

The LTAB and the Optics Assembly Building $(O A B)$ represent the only newly constructed facilities at LLNL. The NIF facilities shall be designed for at least 30 years design life for permanent structures. Systems or portions of systems for which that is impractical shall be designed for ease of replacement. Ease of replacement means that replacement is feasible at reasonable cost and can be accomplished in a timely manner consistent with plant availability requirements. "Replacement" here also includes removal, refurbishment, and reinstallation of original equipment.

The performance category for target are $c_{i}$ and laser structural systems shall be category 2 with a graded approach for other systems.

Where alternative designs and modes of construction are possible at essentially equivalent cost, the design and construction method that most readily allows for future reconfiguration and modification should be selected.

\subsection{Vibration Requirements}

Certain facilities or areas within facilities will house vibration-sensitive special equipment. The structural design of these areas shall provide means to effectively isolate this equipment to control vibration within specified displacement and rotation requirements. Specific constraints are specified in the System Design Requirements for NIF Facilities.

\subsection{Cleanliness Requirements}

The laser bays, experimental areas, and optical assembly rooms must be dust free to prevent laser damage to the optics. Specific constraints are specified in the System Design Requirements for NIF Facilities.

\subsection{Temperature Control}

Temperatures in the laser bays experimental areas must be controlled in order to maintain a stable laser aligrment. Specific constraints are specified in the System Design Requirements. 


\subsection{Electrical Power}

Electric power shall be installed in accordance with NFPA 70, which includes details from the National Electrical Code; IEEE 493, Recommended Practices for Design of Reliable Industrial and Commercial Power Systems; and ANSI C2, the National Electrical Safety Code.

\subsubsection{Voltage Quality}

Voltage shall be maintained in compliance with ANSI C84.1, Electrical Power Systems and Equipment--Voltage Rating (60 HZ). Electrical supply systems shall operate within the limits specified for Range A of this specification. Voltage occurrences outside these limits should not exceed the Range B limits. These variances should be limited in extent, frequency, and duration. Computers shall be protected with low " voltage dropouts requiring manual restart.

\subsubsection{Standby Power}

Standby power shall be available for health, life, property, and safeguards and security loads, including emergency egress lighting, fire alarms and sensors, security systems, and radiation monitors. Power for safety and security functions shall be installed and operated according to NFPA 101, the Life Safety Code; ANSI/NFPA 1101993, the Standard for Emergency and Standby Power Systems; NFPA 72, National Fire Alarm Code; and other applicable NFPA and OSHA standards.

\subsubsection{Uninterruptible Power}

Uninterruptible power systems (UPS), are not required for the NIF facilities or special equipment. 


\subsection{Operational Availability}

User demands for shot time are expected to be high, therefore, the facility shall be designed for maximum reasonable availability and rapid recovery from unplanned shutdowns.

\subsection{Reliability, Availability and Maintainability (RAM)*}

The components, systems, and processes that limit overall facility availability shall be identified during the design process through analyses of turnaround times, mean times between failures, mean times to repair, preventive maintenance requirements, etc. Techniques such as in-site backups, on-hand spares, modular composents, on-call maintenance forces, and more robust designs shall be used to increase availability if the following goals cannot otherwise be achieved:

- The facility shall be available for three shift operations at least 2.53 days per year (73\% availability).

- The facility shall be available for at least 616 no-yield target shots per year. To address, the possible future needs of direct-drive and other users, the design should not preclude an increase in the availability to approximately 1200 total shots per year. The Project shall provide the initial set of maintenance equipment, consisting of at least one unit of each piece of equipment that is required to maintain and operate NIF. Future addition of more units of maintenance equipment shall not be precluded. Continuous high-availability NIF operation, as defined above, may require future additional units of maintenance equipment.

- The lasers shall perform within specification (e.g., laser energy, beam balance, pointing accuracy) on at least $80 \%$ of all shots.

The Project should also use this RAM process to determine how to achieve availability in the most cost-effective manner, to determine what spares in what quantities should be kept in inventory, to optimize turnaround procedures, to plan preventive maintenance and inspection programs, and to respond to unscheduled outages.

\subsection{Recovery Time*}

Because of its importance to the DOE, the NIF shall be designed to survive any abnormal event, including accidents and natural phenomena, expected to occur more frequently than once in 2000 years. The time required to recover from such events is allowed to vary in accordance with the probability of occurrence. Maximum recovery times are specified below. 


\begin{tabular}{|c|c|}
\hline Probability of Occurrence Per Year, $\mathrm{P}$ & Maximum Recovery Time \\
\hline \hline $\mathrm{P}=1$ & 24 hours \\
\hline $1>\mathrm{P} \geq 10^{-2}$ & 1 week \\
\hline $10^{-2}>\mathrm{P} \geq 5 \times 10^{-4}$ & $\begin{array}{l}\text { 3 months for laser, target, and } \\
\text { associated building structures } \\
\end{array}$ \\
& 6 months for support systerins \\
\hline
\end{tabular}

The probabilities of occurrence listed in DOE-STD-1020-94 and DOE-STD-1021-93 shall be utilized for natural phenomena.

Standby power shall be available to preserve process continuity in cases designated by the NIF Project and specified in the System Design Requirements. Neither uninterruptible power systems nor standby power is required for the computer systems. 


\subsection{Decontamination and Decommissioning}

The NIF design shall meet the site-specific requirements. The NIF shall be designed for periodic cleaning of the interior of the test chamber to maintain tritium levels on interior surfaces as low as reasonably achievable. The NIF design shall include considerations that will allow for cost-effective future decommissioning of the structures and equipment.

A plan for NIF Decontamination and Decommissioning (D\&D) shall be developed in accordance with DOE Order 5820.2A, Radioactive Waste Management. A D\&D assessment shall be made during conceptual design to ensure that features and measures are incorporated in NIF to simplify D\&D. The NIF D\&D plan will be prepared before the end of the Title II design. 


\subsection{Quality Assurance**}

The NIF Quality Assurance Program shall meet the requirements of DOE Order 5700.6C, Quality Assurance. As specified in this DOE Order, a graded approach using quality levels based on risk assessment shall be spelled out in the NIF Quality Assurance Program Plan and utilized throughout the Project. The Quality Assurance Program Plan shall cover all aspects of the NIF Project in a phased implementation, beginning with conceptual design. 


\subsection{Orders, Codes, and Standards}

\subsection{DOE Orders*}

The NIF shall be designed and constructed in full compliance with DOE Orders and federal regulations. Exceptions shall be limited to those cases where the Project has formally requested and been granted either an exemption or a finding of equivalency by Headquarters.

It is recognized that updates and additions to DOE Orders, federal regulations, and consensus industry standards are outside of the control of the Project team and are a frequent source of cost and schedule growth. These requirements are all frozen as of March 1, 1996.

\subsection{Codes and Standards}

Technical codes, standards, and guides promulgated by nationally recognized organizations should be utilized by the NIF Project whenever available and practical, per DOE Order 1300.2A. A partial listing of nationally recognized organizations is included in the following sections. Additional references identified during the developmental phases shall be formally cited and controlled in system and subsystem design requirements documents and specifications through the Project Change Control Process.

\subsection{Applicable Orders, Codes, and Standards}

This section lists DOE Orders, codes, and standards in effect on March 1, 1996, that are considered to be applicable to the NIF Project. The listing begins with DOE and other federal regulations (e.g., Resource Conservation and Recovery Act), and is followed by a partial listing of national consensus standards organizations. The applicable portions of these documents will apply.

\subsubsection{DOE Orders}

- 1300.2A - Technical Standards Program

- 5300.4D - Telecommunications: Protected Distribution System

- 5400.1 - General Environmental Protection Program

- 5400.5 - Radiation Protection of the Public and the Environment

- 5480.19 - Conduct of Operations

- 5481.1B - Safety Analysis and Review System (for non-nuclear facilities and hazards only)

- 5632.1C - Protection of Safeguards and Security Interests

- 5633.3B - Control and Accountability of Nuclear Material 
- 5637.1 - Classified Computer Security Program

- 5700.6C - Quality Assurance

- 5820.2A - Radioactive Waste Management

- 151.1 - Comprehensive Emergency Management System

- 430.1 - Life Cycle Asset Management

- N441.2 - Radiological Protection for DOE Activities

- P450.1 - Environment, Safety and Health Policy for the Department of Energy Complex

- 470.1 - Safeguards and Security Program

- 471.2 - Information Security Program

- 472.1 - Personnel Security Activities

10.3.2 Other Government Regulations

- 10 CRR 835 -Occupational Radiation Protection.

- 10 CFR 20 - Standards for Protection Against Radiation

- 29 CFK 1910 - Occupational Safety and Health Act (OSHA) - Operation

- 29 CFR 1926 - Occupational Safety and Health Act (OSHA) - Construction

- 40 CFR 125 - Criteria and Standards for NPDES (National Pollutant Discharge Elimination System)

- 40 CFR 260, 261, 262 - Hazardous Waste Management System

- 40 CFR 61 Subpart H - National Emission Standard for Emissions of Radionuclides other than Radon from Department of Energy Facilities

- FED-STD-209E - Airborne Particulate Cleanliness Classes in Cleanrooms and Clean Zones

- 33 USC 1251 et seq. - Clean Water Act

- 42 USC 7401 - Clean Air Act

- 42 USC 4321 et seq. - NEPA (National Environmental Policy Act)

- 40 USC 6901-6992 - Resource Conservation and Recovery Act (RCRA)

- 15 USC 2601-2692 - Toxic Substance Control Act

\subsubsection{National Consensus Standards}

The NIF Project shall comply with the following national consensus standards, as noted elsewhere in this document:

- ACI 301 - 1996, Specifications for Structural Concrete for Buildings

- ANSI C2 - 1993, National Electric Code

- ANSI C84.1 - 1989, Electrical Power Systems and Equipment-Voltage Rating (60 HZ)

- ANSI Z136.1 - 1993, Laser Safety

- ANSI/RIA R15.06 - 1992, Industrial Robots and Robot System-Safety Requirements

- DOE-STD-1020-94, Natural Phenomena Hazards Design and Evaluation Criteria for DOE Facilities 
- DOE-STD-1021-93, Natural Phenomena Hazards Performance Categorization Guidelines for Structures, Systems, \& Components.

- IEEE 493 1990, IEEE Recommended Practice for the Design of Industrial and Commercial Power Systems

- All NFPA Codes

- NFPA 70 1996, National Electric Code

- NFPA 72 1993, National Fire Alarm Code

- NFPA 101 1994, Code for safety to Life from Fire in Buildings and Structures

- ANSI/NFPA 110-1993, Standard for Emergency and Standby Power Systems

- Uniform Building Code (UBC) 1994

Orders, standards, and codes listed as mandatory in DOE Orders are not necessarily referenced in this list.

In addition to complying with these specific standards, the NIF Project shall utilize applicable and appropriate national consensus codes and standards in the design, procurement, fabrication, installation, construction, inspection, and testing of structures, systems, and components, per DOE Order 1300.2A. Codes, standards, and guides of recognized technical and professional organizations, such as those in the following list, shall be applied as appropriate to NIF materials and workmanship:

$\begin{array}{ll}\text { AA } & \text { Aluminum Association } \\ \text { AASHTO } & \text { American Association of State Highway Officials } \\ \text { ABMA } & \text { American Boiler Manufacturers Association } \\ \text { ACI } & \text { American Concrete Institute } \\ \text { ACGIH } & \text { American Council of Government Industrial Hygienists } \\ \text { AISC } & \text { American Institute of Steel Construction } \\ \text { AISI } & \text { American Iron and Steel Institute } \\ \text { AMCA } & \text { Air Movement and Control Association } \\ \text { ANSI } & \text { American National Standards Institute } \\ \text { APA } & \text { American Plywood Association } \\ \text { ARI } & \text { Air Conditioning and Refrigeration Institute } \\ \text { ARMA } & \text { Asphalt Roofing Manufacturers Association } \\ \text { ASCE } & \text { American Society of Civil Engineers } \\ \text { ASHRAE } & \text { American Society of Heating, Refrigerating \& Air Conditioning } \\ & \text { Engineers } \\ \text { ASME } & \text { American Society of Mechanical Engineers } \\ \text { ASTM } & \text { American Society for Testing and Materials } \\ \text { AWS } & \text { American Welding Society } \\ \text { AWWA } & \text { American Water Works Association } \\ \text { BHMA } & \text { Builders Hardware Manufacturers Association } \\ \text { CISCA } & \text { Ceiling and Interior Systems Contractors Association } \\ \text { CGA } & \text { Compressed Gas Association } \\ \text { CMAA } & \text { Crane Manufacturers Association of America } \\ \text { CRSI } & \text { Concrete Reinforcing Steel Institute } \\ \text { EPRI } & \text { Electric Power Research Institute } \\ \text { FM } & \text { Factory Mutual Engineering and Research 20 20 } 20\end{array}$




$\begin{array}{ll}\text { GA } & \text { Gypsum Association } \\ \text { ICBO } & \text { International Council of Building Officials (Uniform Building Code) } \\ \text { ICEA } & \text { Insulated Cable Engineers Association } \\ \text { IEEE } & \text { Institute of Electrical and Electronics Engineers } \\ \text { IES } & \text { Illuminating Engineering Society of North America } \\ \text { ISA } & \text { Instrument Society of America } \\ \text { NAPHCC } & \text { National Association of Plumbing, Heating, \& Cooling Contractors } \\ \text { NCMA } & \text { National Concrete Masonry Association } \\ \text { NEC } & \text { National Electric Code (NFPA) } \\ \text { NEMA } & \text { National Electrical Manufacturers Association } \\ \text { NIOSH } & \text { National Institute for Occupational Safety and Health } \\ \text { NIST } & \text { National Institute of Standards and Technology } \\ \text { NFPA } & \text { National Fire Protection Standards } \\ \text { RFCI } & \text { Resilient Floor Covering lnstitute } \\ \text { SDI } & \text { Steel Deck Institute } \\ \text { SDI } & \text { Steel Door Institute } \\ \text { SMACNA } & \text { Sheet Metal \& Air Conditioning Contractors National Association } \\ \text { SSPC } & \text { Steel Structures Painting Council } \\ \text { STI } & \text { Steel Tank Institute } \\ \text { SWI } & \text { Steel Window Institute } \\ \text { TCA } & \text { Tile Council of America } \\ \text { TIMA } & \text { Thermal Insulation Manufacturers Association } \\ \text { UL } & \text { Underwriters Laboratories }\end{array}$




\subsection{Revision Record}

\begin{tabular}{|l|l|l|l|l|}
\hline Rev & Date & ECR \# & BCP\# & Description of/Reason for Change \\
\hline \hline 1.3 & $3 / 94$ & $\mathrm{n} / \mathrm{a}$ & $\mathrm{n} / \mathrm{a}$ & CDR release \\
\hline 1.4 & $4 / 1 / 96$ & $\mathrm{n} / \mathrm{a}$ & $96-004$ & $\begin{array}{l}\text { Directed changes in DOE Orders and Federal } \\
\text { Regulations. Miscellaneous changes throughout } \\
\text { document }\end{array}$ \\
\hline 1.4 & $4 / 1 / 96$ & $\mathrm{n} / \mathrm{a}$ & $96-005$ & $\begin{array}{l}\text { Functionality Changes to the NIF Baseline. } \\
\text { Changes include the addition of: optic assembly } \\
\text { capability, beam smoothing, flashlamp cooling, 4x2 } \\
\text { amplifiers, not-to-preclude direct drive, not-to- } \\
\text { preclude radiation effects testing, and laser spot } \\
\text { size. }\end{array}$ \\
\hline 1.4 & $4 / 1 / 96$ & $\mathrm{n} / \mathrm{a}$ & $96-006$ & $\begin{array}{l}\text { Engineering Option Studies: increased shot rate } \\
\text { and full implementation of direct drive. }\end{array}$ \\
\hline 1.5 & $\begin{array}{l}12 / 18 / \\
96\end{array}$ & 80,81 & $97-001$ & $\begin{array}{l}\text { Title I Update of Functional Requirements/Primary } \\
\text { Criteria. Changes to incorporate results of Title I } \\
\text { design and design review, update of DOE Orders } \\
\text { and standards, and miscellaneous changes }\end{array}$ \\
\hline 1.6 & $3 / 10 / 97$ & 96 & $97-004$ & $\begin{array}{l}\text { Typographical changes and minor wording } \\
\text { changes to reflect completion of ROD and final } \\
\text { incorporation of Necessary and Sufficient } \\
\text { Standards }\end{array}$ \\
\hline
\end{tabular}




\section{Appendix K}

NIF Project Completion Criteria 


\section{NIF Project Completion Criteria}

Physical Status

- Construction Completed (beneficial occupancy)

- LTAB

$-\mathrm{OAB}$

- Central Plant

- Site Utilities

- Required Equipment in Place and Acceptance Tested

- Assembly Installation and Refurbishment Equipment (including 3 transporters and OAB equipment)

- Beampath infrastructure system for 192 beamlines

- Line replaceable units for 192 beamlines assembled, installed, and acceptance tested

- Target Area Building and Chamber, including

- Flexibility in Beam Dump placement (NWET)

- Equitorial ports available to allow direct drive irradiation symmetry

- Designed for a routine DT fusion yield of $20 \mathrm{MJ}$ (50 shots/yr) with capability to withstand a maximum credible yield of $45 \mathrm{MJ}$ ability to perform yield shots with total DT fusion yield of $1200 \mathrm{MJ} / \mathrm{yr}^{*}$

- Target Positioner(s) and 4 Diagnostic Instrument Manipulators (DIM)

- Diagnostics sufficient to demonstrate laser performance requirements

- Classified Data Acquisition capability and Control Room As required to support SRD

- Project provides sufficient spares for project construction

\section{Laser Performance Requirements}

\begin{tabular}{|l|l|l|}
\hline & 96 Beam Performance & Single Bundle Performance \\
\hline Pulse Energy & $500 \mathrm{~kJ}$ & $75 \mathrm{~kJ}$ \\
Peak Power & $200 \mathrm{TW}$ & $21 \mathrm{TW}$ \\
Wavelength & $.35 \mu \mathrm{m}$ & $.35 \mu \mathrm{m}$ \\
Positioning Accuracy & $100 \mu \mathrm{m} \mathrm{rms}$ at target plane & $100 \mu \mathrm{m}$ \\
Pulse Duration & $20 \mathrm{~ns}$ & $20 \mathrm{~ns}$ \\
Pulse Dynamic Range & $>25: 1$ & $50: 1$ \\
Pulse Spot Size & $600 \mu \mathrm{m}$ & $600 \mu \mathrm{m}$ \\
Pre-pulse power & $<10^{8} \mathrm{~W} / \mathrm{cm}^{2}$ & $<4 \times 10^{6} \mathrm{~W} / \mathrm{cm}^{2}$ \\
Cycle Time & 8 hours max between full & 8 hours max between full \\
& system shots & system shots \\
\hline
\end{tabular}

\section{Documentation}

All documentation required to support the Defense Programs Office of the NIF Readiness Assessment

\footnotetext{
- The NIF design shall provide for life-cycle cost effective future addition of components that are needed only for high yield operation and are therefore not needed in the first 3-5 years of operation such as shield doors and decontamination equipment.
} 